\title{
Cinsiyet Eşitliği ve Çocuğun Üstün Yararının Kesişim Noktası Olarak Boşanmada Velayetin Düzenlenmesi
}

\author{
Özgün Çelebi* (1)
}

Öz

Boşanma sonrasında çocuğun velayetinin kimin tarafindan icra edileceği sorunu evrensel bir ilke olan çocuğun üstün yararı ilkesi çerçevesinde çözümlenmektedir. Ancak her ne kadar görünürde cinsiyetsiz bir ilke olsa da, kavramın belirsizliğinin yarattğı sakıncalardan birinin, anne ile baba arasında cinsiyete dayalı ayrımcı çözümlere kapı açması olduğu düşünülmektedir. Bu nedenle velayet konusu, gittikçe artan biçimde kadın-erkek eşitliği ile ilişkisi çerçevesinde gündeme gelmekte, velayet hukuku ile cinsiyet eşitliği arasındaki ilişki hem kadın haklarına hem de çocuk haklarına ilişkin uluslararası belgelerde karşımıza çıkmaktadır. Bu çalışmada, boşanma sonrası velayetin düzenlenmesi sorunu bağlamında, cinsiyetsiz bir kural gibi görünen çocuğun üstün yararı ilkesinin yorumlanma biçimlerinin cinsiyet eşitliği ile ilişkileri incelenecektir. Bu çerçevede, çocuğun üstün yararı ilkesini somutlaştrrmak için farklı hukuk sistemlerinde ve ülkemizde uygulanan veya uygulanması önerilen anne şefkatine muhtaç olma ölçütü, birincil bakıcı ölçütü ve ortak velayet çözümünün cinsiyet eşitliği amacını gerçekleştirmeye yakın olup olmadıkları irdelenecektir. Elde edilen bulgular çerçevesinde çocuğun üstün yararı ilkesi ile cinsiyet eşitliği hedeflerini bağdaştrabilecek bir velayet hukukunun mümkün olup olmadığı tartışılacaktır.

\section{Anahtar Kelimeler}

Velayet, Çocuğun üstün (Yüksek) yararı, Cinsiyet eşitliği, Anne şefkatine muhtaç olma, Ortak velayet

Allocation of Child's Custody After Divorce as the Junction Point of Gender Equality and the Child's Best Interest

\begin{abstract}
Allocation of a child's custody after divorce relies upon the universal principle of the child's best interest. Nevertheless, it is argued that despite its seemingly gender-neutral nature, one of the shortcomings caused by the uncertainty of such a principle is that it paves the way for gender discrimination. As a result, the topic of child custody has increasingly been mentioned in the framework of equality between men and women, as shown by references made to the relationship between custody law and gender equality both in international instruments relating to women's rights and in those relating to children's rights. In this paper we analyze the relationship between different interpretation methods of the seemingly gender-neutral principle of the child's best interest and gender equality in the context of allocation of custody after divorce. We go through the tender years, primary caretaker and joint custody concepts, which are the methods used or proposed to be used to concretize the principle of the child's best interest in different law systems and in Turkish law and contemplate whether they enable to achieve the goal of gender equality. On the grounds of these findings we discuss whether it is possible to achieve a child custody law which can reconcile the principle of the child's best interest with gender equality.
\end{abstract}

\section{Keywords}

Custody, Best interest of the child, Gender equality, Tender years doctrine, Joint custody

* Sorumlu Yazar: Özgün Çelebi (Dr. Öğr. Üyesi), Koç Üniversitesi, Hukuk Fakültesi Medeni Hukuk Anabilim Dalı, İstanbul, Türkiye. E-posta: ozgcelebi@ku.edu.tr ORCID: 0000-0003-0610-6992

Atrf: Celebi O, “Cinsiyet Eşitliği ve Çocuğun Üstün Yararının Kesişim Noktası Olarak Boşanmada Velayetin Düzenlenmesi” (2021) 79(1) İstanbul Hukuk Mecmuası 27. https://doi.org/10.26650/mecmua.2021.79.1.0002 


\section{Extended Summary}

The problem of allocation of a child's custody after divorce of the parents is resolved following the universal principle of the child's best interest. This standard has a high level of popularity due to its flexible character, allowing for consideration of specific circumstances of each concrete case. Nevertheless, such flexibility is also a source of uncertainty and unpredictability. It is argued that one of the shortcomings of its uncertain character is that it creates a large margin of discretion for the courts and such discretion may lead to discrimination between men and women. Indeed, in disputes relating to custody, prejudices regarding social roles of men and women may shape the decisions in a way to disfavor fathers or mothers. As a result, custody law related questions are increasingly correlated to problems of gender equality. International conventions and policy instruments more and more frequently refer to the connection between gender equality and parental responsibility. In this regard, the goal of ensuring equality between men and women appears to have become one of the main issues that must be carefully reflected upon while shaping the custody law and determining how to interpret the child's best interest in custody disputes.

In order to overcome the shortcomings caused by the breadth of the concept of the child's best interest, some legal systems have adopted presumptions, where a certain solution is accepted to be in the best interest of the child as a general rule. Although it is no longer consecrated by lawmakers, the "tender years doctrine", giving the priority to mothers when it comes to the custody of young children is still being applied under the best interest standard. "Primary caretaker doctrine", which is based on the idea of according the custody to the parent who has acted as the primary caretaker of the child during the marriage has also been applied as a general rule in some legal systems. In the recent years, these solutions have begun to lose their attractiveness and yield to the more modern concept of joint custody, which is usually regulated in the form of a presumption. Joint custody is embraced as a general solution to the problem of custody and is currently argued to be the best solution, not only from the perspective of the child's interest, but also from the perspective of equality between the parents. In its commonly accepted form, as can be observed in continental law systems, such presumption of joint custody creates a situation of shared parenting which is independent from the past decision-making and caregiving patterns. The American Law Institute's Principles of the Law of Family Dissolution depart from this conception by putting forward the "approximation rule", which is also based on a conception of shared parenting but which presumes that the best interest of the child resides in the continuation of the past parenting patterns.

This paper addresses the custody law and especially the seemingly genderneutral principle of the child's best interest in custody disputes after divorce from the perspective of gender equality. It analyzes the relationship between the above- 
mentioned presumptions regarding the best interest of the child and equality between parents. To this effect, first, we explain the importance and relevance of such problems by presenting the legal framework regarding the connection between gender equality and children's rights. Then we present the function of the best interest standard in custody disputes together with the criticism of this standard from a gender perspective. We undertake a comparative law study, englobing continental law systems and American law, where we detect different solutions, usually in the form of presumptions, brought by foreign legal systems to provide a certain level of predictability to the best interest standard and analyze the impact of such presumptions on the goal of ensuring shared responsibility between mother and father. The situation in Turkish law, where the tender years doctrine is still applied by the courts and where joint custody has recently begun to come to the surface is also explained and analyzed from a gender perspective. A study of different models of interpretation of the child's best interest leads us to the conclusion that the sole presumptive solution which can have a positive impact in terms of gender equality is the presumption of joint custody which perpetuates the past parenting patterns, as proposed by the American Law Institute. However, we find that the solution proposed by the American Law Institute is faced with practical difficulties of implementation and may thus not provide the benefits expected. As a result, we find that a custody law which efficiently promotes shared parenting should focus on drawing a nondiscriminative guideline and presenting a method of reasoning for courts, rather than having recourse to presumptions, which cannot effectively combat gender-based considerations in the field of custody. 


\section{Cinsiyet Eşitliği ve Çocuğun Üstün Yararının Kesişim Noktası Olarak Boşanmada Velayetin Düzenlenmesi}

\section{Giriş}

Hukukumuzda velayetin kimin tarafından icra edileceğinin belirlenmesinde temel ayrım noktası anne ve babanın evli olup olmamasıdır. Türk Medeni Kanunu (TMK), anne ve babanın evli olmaması halinde velayetin kural olarak anneye ait olacağını öngörmüştür (TMK m 337/I); anne ve babanın evli olması halinde, evlilik devam ettiği sürece anne ve baba velayeti birlikte kullanacaklardır (TMK m 336/I). Eşlerin boşanması halinde ise ortak hayat nihai olarak sona ermekte, o zamana kadar ortak biçimde kullanılan velayetin, bundan sonra ne şekilde kullanılacağını belirleme gereği hâsıl olmaktadır. Türk Medeni Kanunu'nun konuya ilişkin düzenlemesinden kanun koyucunun, velayetten doğan yetkilerin kullanımı ile çocuğun fiilî bakımının üstlenilmesi konularını yakın ilişki içinde gördüğü anlaşılmaktadır (TMK m 336/ III) ${ }^{1}$. Nitekim kanun koyucu, bir ebeveynden fiziksel olarak ayrilmanın velayetin de o ebeveynden koparılması sonucuna götüreceğini düşünerek hâkime anne ile babadan birini velayeti bundan sonra icra edecek kişi olarak belirleme görevi yüklemiş görünmektedir².

Hukukumuz da dâhil olmak üzere, çağdaş hukuk sistemlerinde boşanma sonrasında velayetin anne veya babadan hangisine verileceği meselesi, 20 Kasım 1989'da New York'ta kabul edilen Birleşmiş Milletler Çocuk Haklarına Dair Sözleşme (Çocuk Haklarına Dair Sözleşme)'nin de etkisiyle evrensel bir ilke haline gelmiş olan "çocuğun üstün (yüksek) yararı" (best interest of the child) ilkesine göre çözümlenmektedir ${ }^{3}$. Bununla beraber, dünyadaki gelişmeler, anne ve babanın çocuğa karşı hak ve yükümlülüklerinin, bu arada velayet ilişkisinin, cinsiyet eşitliğine ilişkin bir sorun olarak da algılanmaya başlandığını göstermektedir. Bunun en net ifadesini, asli amacı cinsiyet eşitliğini sağlamak olan hukuk kurallarının ve politika belgelerinin ebeveyn-çocuk ilişkilerini bu perspektif dâhilinde zikreder hale gelmiş olmasında görüyoruz. Bu evrensel gidişat hukukumuzu da etkilemektedir. Hukukumuz açısından bağlayıcı kurallara bakıldığında öncelikle Anayasa'nın 41. maddesinde ailenin "eşler arasında eşitliğe" dayalı olduğunun ifade edildiği görülmektedir. Kadınlara Karşı Her Türlü Ayrımcılığın Önlenmesi Sözleşmesi’nin (KKAÖS) 4 16. maddesinde, taraf devletlerin kadınlara karşı ayrımcılığın önlenmesi ile yükümlü oldukları konular sayılmıştır. Bunlar arasında kadına ve erkeğe evlilik süresince ve evliliğin son

\footnotetext{
"Velâyet, ana ve babadan birinin ölümü hâlinde sağ kalana, boşanmada ise çocuk kendisine biraklan tarafa aittir."

2336. maddenin üçüncü fikrasının lafzından yola çıkan ve hukukumuzda boşanma sonrasında velayetin ebeveynlerden biri tarafından tek başına kullanılması gerektiği sonucuna götüren bu geleneksel önerme tartışmalıdır; hukukumuzda ortak velayetin mümkün olup olmadığı konusundaki görüşler ve uygulama için bkz aş III-A.

3 Çocuk Haklarına Dair Sözleşme'nin onaylanmasına ilişkin 94/6423 sayılı Bakanlar Kurulu kararı ile sözleşme metni 27 Ocak 1995 tarihli, 22184 sayılı Resmî Gazete'de yayımlanmıștır.

4 Sözleşmeye katılmamızın onaylanmasına ilişkin 85/9722 sayılı Bakanlar Kurulu kararı ve sözleşme metni 14 Ekim 1985 tarihli, 18898 sayılı Resmî Gazete'de yayımlanmıștır.
} 
bulmasında aynı hak ve sorumlulukların tanınması (c) ve her durumda çocukların menfaatleri en ön planda gözetilmek üzere, medeni durumlarına bakılmaksızın, çocuklarla ilgili konularda ana ve babanın eşit hak ve sorumluluklarının tanınması (d) da bulunmaktadır. Avrupa İnsan Hakları Sözleşmesi’ne ek 7 numaralı protokolün ${ }^{5}$ "Eşler arasında eşitlik" kenar başlıklı 5. maddesi, eşlerin evlilikte, evlilik süresince ve evliliğin sona ermesi durumunda, kendi aralarında ve çocukları ile ilişkilerinde özel hukuka tabi haklar ve sorumluluklar bakımından eşit olmaları gerektiğini öngörmüştür. Hukuk sistemimizin parçası olan bu kurallar, doğrudan doğruya kadınerkek eşitliğini sağlama amacı üzerine yükselmekte ve ebeveyn sorumluluğunda eşitliği bu perspektif kapsamında düzenlenmektedirler. Öte yandan çocuk hakları ve çocukların korunmasına ilişkin politikalar da gittikçe artan biçimde kadın erkek eşitliği sorunu ile iç içe geçmiş biçimde karşımıza çıkmakta ${ }^{6}$, hatta çocukların menfaatlerini korumayı birincil amaç olarak benimseyen uluslararası belgelerde dahi cinsiyet eşitliğinin ikincil, ancak bağımsız bir amaç olarak yer aldığı görülmektedir. Avrupa Konseyi'nin çocukların korunmasına ilişkin bazı kararlarında tam da bu yönde bir yönelim hâkimdir. Avrupa Konseyi Bakanlar Komitesi nin (84) 4 sayılı Anne ve Babanın Sorumlulukları Hakkında Tavsiye Kararı'nda ebeveyn sorumluluklarının her iki ebeveyne ortak biçimde ait olduğu ilkesi benimsenmiştir (5 numaralı ilke) ${ }^{7}$. Buna göre ayrılık veya boşanma halinde karar organının sorumlulukları anne ve baba arasında paylaştırması veya anne ve baba buna rıza gösterirlerse sorumluluklarını birlikte yerine getirmeleri yönünde karar vermesi gerekmektedir (6 numaralı ilke). İlgili tavsiye kararında, çocuğun üstün yararına göre karar alınması temel ilke olarak benimsenmekle beraber, anne ve baba arasında eşitliğin korunmasına dikkat edilmesi ve ayrımcılık yapılmaması gerektiği de açık olarak belirtilmiştir ( 2 numaralı ilke). Avrupa Konseyi Parlamenter Meclisi’nin 2079 sayılı Eşitlik ve Paylaşılmış Ebeveyn Sorumluluğu: Babaların Rolü isimli ilke kararında ise çocuğun doğumundan itibaren anne ve baba arasında eşitliğin sağlanması gerektiğine vurgu yapılmıştır ${ }^{8}$. Bu gereklilik bir yandan her iki ebeveynin de çocuğun yetiştirilmesine katılmalarının çocuk üzerindeki olumlu etkisine, diğer yandan ortak sorumluluğun kadına ve erkeğe ilişkin kalıplaşmış rollerin aşılmasına yardımcı olmasına dayandırılmıştır. Kararda

\footnotetext{
Protokolün onaylanmasının uygun bulunduğuna dair 6684 sayılı kanun 25 Mart 2016 tarihli ve 29664 sayılı Resmî Gazete'de yayımlanmıştır.

6 Örneğin, Avrupa Konseyi Parlamenter Meclisi’nin 2207 numaralı kararında tek ebeveynli ailelerde aile reisinin büyük ölçüde kadınlar olduğu, çocuk nafakasının belirlenmesine ve ödenmemesinin sonuçlarına ilişkin kuralların kadınları orantısız biçimde etkilediği, bu nedenle çocuk nafakası konusunun cinsiyet eşitliğinden bağımsız bir konu olmadığı belirtilmiştir (PACE, 'Gender Equality and Child Maintenance' (2018) Resolution No 2207, <https://assembly.coe.int/nw/ $\mathrm{xml} /$ XRef/Xref-XML2HTML-en.asp?fileid=24534\&lang=en> Erișim Tarihi 11.05.2020). Parlamenter Meclisi, 1921 say1l kararında da kadın ve erkeğin, çocuk bakımı da dâhil olmak üzere aile içi sorumlulukları paylaşmaları gerektiği yönündeki farkındalığın özel hayat ile çalışma hayatını bağdaştırmanın şartlarından biri olduğunu belirtmiştir (PACE, 'Gender Equality, Reconciliation of Private and Working Life and Co-Responsibility' Resolution No 1921, < https://assembly.coe. int/nw/xml/XRef/Xref-XML2HTML-en.asp?fileid=19478\&lang=en> Erişim Tarihi 11.05.2020).

Council of Europe Committee of Ministers, 'Recommendation of the Committee of Ministers to Member States on Parental Responsibilities', Recommendation No R (84) 4, <https://search.coe.int/cm/Pages/result_details. aspx?ObjectID=09000016804de2e4> Erişim Tarihi 11.05.2020.

8 PACE, 'Equality and Shared Parental Responsibility: The Role of Fathers' (2015) Resolution No 1468, <http:/assembly. coe.int/nw/xml/XRef/Xref-XML2HTML-EN.asp?fileid=22220> Erişim Tarihi 11.05.2020.
} 
cinsiyet eşitliği ve paylaşılmış sorumluluk meselesine, annelerin durumundan ziyade babaların maruz kaldığı önyargılar ve bu önyargıların babaları çocuklarıyla kalıcı bir ilişki sürdürme imkânından mahrum etmesi açısından yaklaşılmış olması da dikkat çekicidir. Belirtelim ki Parlamenter Meclisi bu kararda babaların haklarını zikrederken, babaların çocuğun doğumundan itibaren sorumluluk yuklenmelerinin ve devletlerin babaların da kullanabilecekleri ebeveynlik izni sistemlerini yürürlüğe koymalarının gerektiğinin altını çizmiştir ${ }^{9}$. Böylece sorumluluk paylaşımında sadece boşanma sonrasında geçerli olacak bir eşitlik anlayışı yerine anne ve babayı aile ilişkisinin tüm aşamalarında eşit kılan bütüncül bir yaklaşım benimsenmiş olmaktadır. Anne ve babayı eşit hak ve sorumluluklara sahip kılma yönündeki bu uluslararası ilkesel eğilim, Kadınlara Yönelik Şiddet ve Aile İçi Şiddetin Önlenmesi ve Bunlarla Mücadeleye İlişkin Avrupa Konseyi Sözleşmesi'nde işaret edildiği gibi, ancak kadınları şiddete karşı koruma amacı çerçevesinde geri plana atılmakta, şiddet unsurunun eşit hak ve sorumluluk paylaşımını bertaraf edici etkisinin olması gerektiği kabul edilmektedir ${ }^{10}$. Bununla beraber, kadınları şiddete karşı koruma amacı güden düzenlemelerin amaçları arasında, sadece kadınların bireysel dokunulmazlık alanlarının korunması değil, şiddet eylemi veya tehdidi ile yapılan baskının ve bu yolla yaratılan cinsiyetler arası eşitsizliğin ortadan kaldırılması da bulunmaktadır ${ }^{11}$. $\mathrm{Bu}$ uzun vadeli hedef dikkate alındığında, çocuk ile ebeveyn ilişkilerindeki eşitlik idealinde şiddet nedeniyle yapılması kabul edilen esnemelerin de esasında kadınerkek eşitliğini sağlama amaciyla uyum içinde olduğu söylenebilir.

$\mathrm{Bu}$ düzenlemeler 1şığında görülmektedir ki kadın ile erkek arasındaki doğrudan ilişkiler kadar anne ve babanın çocukla kuracağı ilişkilerin de kadın-erkek eşitliği hedefinin kapsamında değerlendirilmesi gerekmektedir. Gerek velayetin iki ebeveyn tarafından ne şekilde kullanılacağının, gerekse birlikte kullanılmadığı hallerde hangi ebeveyn tarafından kullanılacağının belirlenmesi, bu eşitlik hedefini de göz önüne almayı zorunlu kılmaktadır.

Ancak çocukları etkileyecek kararların verilmesi gereken bu hallerde, kadınerkek eşitliğinin tek, hatta birincil parametre olarak ele alınamayacağı ortadadır.

Erkeklerin bakım sorumluluğu üstlenmeye teşvik edilmeleri, Avrupa Konseyi’nin cinsiyete dayalı kalıplarla mücadele çerçevesinde ele aldığı noktalardan biridir; bkz Council of Europe, 'Gender Equality Strategy 2018-2023' 16-19, <https:// rm.coe.int/strategy-en-2018-2023/16807b58eb> Erişim Tarihi 11.05.2020.

10 Kadınlara Yönelik Şiddet ve Aile İçi Şiddetin Önlenmesi ve Bunlarla Mücadeleye İlişkin Avrupa Konseyi Sözleşmesi (İstanbul Sözleşmesi)'nin amaçları arasında kadınların her türlü şiddetten korunması, kadınlara yönelik şiddetin ve aile içi şiddetin önlenmesi, kovuşturulması ve ortadan kaldırılması bulunmaktadır (m 1 (a)). Sözleşme taraf devletlere velayet ve ziyaret haklarının düzenlenmesinde șiddet eylemlerinin göz önünde bulundurulmasını ve bu hakların kullanımının mağdurun veya çocukların haklarını ve güvenliğini tehlikeye düşürmemesini sağlamak üzere gerekli tedbirleri alma yükümlülügünü yüklemektedir (m 31); 'Council of Europe Convention on Preventing and Combating Violence Against Women and Domestic Violence' (2011) Treaty No 210, <https://www.coe.int/en/web/conventions/full-list/-/conventions/ rms/090000168008482e >, Erişim Tarihi 11.05.2020. Sözleşmeye katılmamızın onaylanmasına ilişkin 2012/2816 sayılı Bakanlar Kurulu kararı ve sözleşme metni 8 Mart 2012 tarihli, 28227 (Mükerrer) sayılı Resmî Gazete'de yayımlanmıştır.

11 İstanbul Sözleşmesi'nde amaçlar arasında sadece kadınların şiddete karşı korunmalarının değil, aynı zamanda kadınlara yönelik ayrımcılığın ortadan kaldırılmasına katkıda bulunulmasının ve kadınların güçlendirilmesi yoluyla eylemli kadınerkek eşitliğinin sağlanmasının da zikredilmiş olması (m 1 (b)), cinsiyete dayalı şiddet ile cinsiyete dayalı toplumsal hiyerarşi ve ayrımcılık arasındaki bağı vurgulamakta ve kadına karşı şiddetle mücadelenin ayrımcılıkla mücadelenin ayaklarından biri olduğunu ortaya koymaktadır. 
$\mathrm{Bu}$, asli amacı kadın haklarının korunması olan belgelerde bile özellikle altı çizilen bir noktadır ${ }^{12}$. Nitekim çocukların menfaatlerinin devreye girdiği hallerde çocuğun üstün yararı ilkesi, yine hukuki bağlayıcılık taşıyan ve diğer temel ilkeleri arka planda bırakabilecek güce sahip bir ilke olarak karşımıza çıkmaktadır. Bu durumda esasında çocukları korumaya yönelmiş olan velayet konusunun neden cinsiyet eşitliğinin sağlanması amacı ile ilişkilendirilmeye başlandığı sorusunu cevaplamak gerekir. Nitekim burada eşitlik düşüncesi ile izlenen amacın münhasıran çocuğun menfaatlerine yönelik olmadığı, eşler arasındaki ayrımcılığın önlenmesinin çocuğun yararının korunmasını sağlayan araçlardan biri olmanın ötesinde, çocuğun yararı değerlendirilirken mümkün olduğu kadar dikkate alınması gereken bir amaç olarak benimsendiği açıktır.

Kanımızca velayet konusunun cinsiyet eşitliği ile ilişkilendirilmesinin sebebini çocuğun üstün yararı kavramının genişliğinde ve sübjektif niteliğinde, dolayısıyla başka amaçlara ulaşılmak için kolaylıkla araç haline getirilebilir olmasında bulmak mümkündür. Çocuğun yararı kavramına tanınan meşruiyet, kavramı uygulamaya koyan mercilerin bu kavramı nasil kullanabilecekleri veya ona nasıl bir anlam yükleyebilecekleri hususunda sınır koymamaktadır ${ }^{13}$. Çocuğun yararını tespit ederken ulaşmaya çalıştı̆̆ımız amaçlar çeşitlilik gösterirler ve bazen birbirleriyle çelişirler. Çocuğun yaşam koşullarında istikrarın sağlanması, duygusal ve fiziksel sağlığının gözetilmesi, güvenliğinin sağlanması, akademik başarısının desteklenmesi, iyi bir vatandaş olarak yetiştirilmesi ve buna benzer amaçların her biri çocuğun yararı ile gerekçelendirilebilir ve somut bir olayda bunlar velayet açısından aynı çözüme işaret etmeyebilir ${ }^{14}$. Karar alan kişinin kişisel öncelikleri ve değer yargıları sürece ister istemez etki etmekte ve bu değer yargıları bazen çocuğun yararı kisvesi altında başka bazı toplumsal değerleri veya başka kişilerin hukuki menfaatlerini öncelemekte veya zedelemektedir. Yapısı itibariyle farklı cinsiyetteki iki kişiyi karşı karşıya getiren velayete ilişkin ihtilaflarda en çok zedelenmeye müsait değerler de eşitliğe ilişkin değerler olmaktadır; nitekim karar alma organının cinsiyet rollerine ilişkin kişisel fikirleri, çocuğun yararının nerede olduğuna ilişkin yargısını da şekillendirebilmektedir ${ }^{15}$. Dolayısıyla velayet hukukunun nasıl düzenlendiği ve bu çerçevede çocuğun üstün yararı belirlenirken ne tür bir yorum yapıldığı, bir yandan kadına ve erkeğe yüklenilen rol paylaşımını yansıtmakta, öte yandan rol paylaşımını etkileyici işlev görmektedir. Başka bir deyişle velayete ilişkin kurallar

12 Örneğin bkz KKAÖS m 16 (d).

13 Françoise Dekeuwer-Defossez, 'L'intérêt (supérieur) de l'enfant : consensus, instrumentalisation ou subversion ?' iç Emmanuel Putman, Marie-Ėve Pancrazi, Michel Buy, Bertrand Fages, Anne Laude, Dominique Velardocchio, Mélanges en l'honneur de Jacques Mestre, (LGDJ 2019) 346; Angela Marie Caulley, 'Equal Isn't Always Equitable: Reforming the Use of Joint Custody Presumptions in Judicial Child Custody Determinations' (2018) 27 (2) Boston University Public Interest Law 403, 417.

14 Katherine T Bartlett, 'Child Custody in the 21st Century: How the American Law Institute Proposes to Achieve Predictability and Still Protect the Individual Child's Best Interests', (1999) 35(3) Willamette Law Review 467, 468.

15 Erika R Schwarz, 'When Neutral Doesn't Really Mean Neutral: Louisiana's Child Custody Laws - An Attempt to Erase Gender Bias in the Name of Neutrality' (1996) 42 Loyola Law Review 365; Caulley (n 13) 418. 
ve kararlar, kadın ile erkeğin sosyal rollerine ilişkin kalıpların hem aynası hem de üreticisi olmaktadir ${ }^{16}$. Tam da bu sebeple velayet hukuku, anne ve babaların cinsiyet temelinde gruplandığı ve bu grupların kendi menfaatlerini çocuğun yararı kılığına büründürdüğü bir savaş alanı olarak karşımıza çıkmaktadır ${ }^{17}$. Anne ve baba gruplarının çocuğun yararına ilişkin birbiriyle bağdaşmaz argümanları karşısında karar organı, kendi kişisel fikirlerine göre çocuğun yararının nerede olduğunu tespit etmektedir $^{18}$. İşte bu nedenledir ki, hukukumuzda da etki doğuran evrensel velayet hukuku ilkeleri bir yandan çocuğun yararını üstün ilke olarak esas almakta, öte yandan bu ilkenin uygulanma biçiminin cinsiyet eşitliğine uygunluğunu sağlamanın, daha açık bir ifadeyle ilkenin cinsiyet ayrımcılığına kılıf olmasının önüne geçmenin yollarını aramaktadırlar.

Cinsiyetsiz kurallar hukuki eşitliğin sağlanması için bir başlangıç noktası teşkil ederler. Ancak kuralın cinsiyetsiz biçimde formüle edilmesi, ayrımcı itkilerin hâkimlerin kişisel görüşleri vasıtasıyla karar alma sürecine dâhil olmasının da yolunu açabilir; bu nedenle cinsiyetsiz kuralların uygulanma biçimlerine ve doğurdukları sonuçlara da dikkat edilmesi zorunludur ${ }^{19}$. Bu çalışmada, boşanma sonrası velayetin düzenlenmesinde, cinsiyetsiz bir kural gibi görünen çocuğun üstün yararı ilkesinin yorumlanma biçimlerinin cinsiyet eşitliği ile ilişkisi ortaya konulacak, her biri çocuğun üstün yararına dayandığı iddiasında olan farklı velayet modelleri cinsiyet eşitliği ile ilişkileri bağlamında incelenecektir ${ }^{20}$. Bu amaçla öncelikle velayetin düzenlenmesinde çocuğun üstün yararı kavramına değineceğiz (I). Ardından kavrama getirilen eleştirilerin işaret ettiği sakıncaları aşmak amacıyla, velayette çocuğun üstün kavramının kapsamının daraltılmasına ilişkin uygulanan veya uygulanması önerilen hukuki modeller cinsiyet eşitliği ile olan ilişkileri çerçevesinde incelenecektir (II). Akabinde Türk hukukunda velayete ilişkin ihtilaflarda çocuğun üstün yararı

16 Benzer yönde Amélie Dionisi-Peyrusse ve Marc Pichard, 'L'autorité parentale et la persistance des inégalités de genre iç Stéphanie Hennette Vauchez, Marc Pichard, Diane Roman (edr), La loi et le genre, Études critiques de droit français ( CNRS 2014) 485.

17 Herma Hill Kay, 'No-Fault Divorce and Child Custody: Chilling out the Gender Wars' (2002) 36 (1) Family Law Quarterly 27, 30; Dekeuwer-Defossez (n 13) 350.

18 Dekeuwer-Defossez (n 13) 351; bazı yazarlara göre bu nedenle çocuğun yararına ilişkin unsurların şeffaf hale getirilmesi ve eleştirel bir bakışa tabi tutulması, kavramın içeriğinin disiplinler arası ve daimi bir diyalog halinde belirlenmesi gerekir, bkz Andrea Büchler ve Rolf Vetterli, Ehe Partnershaft Kinder (3. Bas1, Helbing Lichtenhahn 2018) 244.

19 Cinsiyetsiz kanunlar önyargıları ortadan kaldırmayı amaçlarken yargısal sonuçların tam da bu önyargıları yansıttığı yönünde, bkz Schwarz (n 15) 365.

20 Her ne kadar boşanma sonrası velayet konusu ile evlilik dışı doğan çocuğun velayeti konusu genel olarak birlikte düşünülse ve ortak velayeti benimseyen hukuk sistemlerinde benzer kurallara tabi tutulsa da, fikrimizce bu iki mesele cinsiyet eşitliği açısından farklı dinamikler barındırmaktadır. Evlilik dışı doğan çocukların velayetinde çocukla ebeveynler arasında doğumdan itibaren geçerli olacak bir ilişkinin doğru biçimde tesis edilmesinin yolları aranmaktadır. Çocuğun doğumundan itibaren geçerli olacak eşitlikçi bir görev dağılımı, anne ve babanın çalışma hayatına görece eşit biçimde katılmalarını teşvik edebilir ve kadınlar ve erkekler arasında aile dışında da geçerli olan eşitsizliklerin törpülenmesini sağlayabilir. Boşanma sonrasında velayetin düzenlenmesinde ise o zamana kadar belirli bir şekilde süregelmiş ilişki sonradan değişmektedir; ebeveynler arasında eşitliğin ilk defa bu noktada kurulmaya çalışılması, o ana kadar çocuğun bakımını fiilen üstlenmiş kișinin, hem aile dıșı hayatta aktif olma imkânını, hem de bu bakım ilișkisinden kaynaklanan avantajlarını kaybetmesine yol açabilir. Aile içi görev dağılımında gerçekleştirilememiş eşitliğin, ayrılık sonrası kurulmaya çalışılmasının kadın-erkek eşitliği ilkesinin özü ve amacı ile ne kadar bağdaştığı tartışma götürür. Bu iki konunun kendi iç dinamiklerine göre ele alınması gerektiğini düşündüğümüzden, çalışmanın hacmini arttırmamak için evlilik dışı doğan çocukların velayeti konusu çalışmanın kapsamı dışında bırakılmıştır. 
kavramının nasıl yorumlandığı yine cinsiyet eşitliği ilkesi ile ilişkisi çerçevesinde tanitilacaktır (III).

\section{Velayetin Düzenlenmesinde Çocuğun Üstün Yararı Kavramının Rolü}

Türk Medeni Kanunu, velayetin eşlerden birine bırakılmasına ilişkin hükümlerinde hâkimi sınırlandırıcı herhangi bir parametre koymamış, hâkime geniş bir takdir yetkisi tanımışı ${ }^{21}$. Kanunda çocuklara ilişkin kararların ne şekilde alınacağını belirten genel nitelikte bir hüküm de bulunmamaktadır ${ }^{22}$. Bununla beraber, bu konuda esas alınacak ölçütün "çocuğun yararı" olduğu şüphe götürmez ${ }^{23}$. Çocuğun üstün yararının gözetilmesi gereği, her şeyden önce anayasal bir ilkedir ${ }^{24}$. Anayasa'nın 41. maddenin ikinci fikrası "Devlet, ailenin huzur ve refahı ile özellikle ananin ve çocukların korunması ve aile planlamasının öğretimi ile uygulanmasını sağlamak için gerekli tedbirleri alır, teşkilatı kurar" hükmünü içermektedir. Maddeye 2010 y1lında eklenen üçüncü fikra ile "Her çocuk, korunma ve bakımdan yararlanma, yüksek yararına açıkça aykırı olmadıkça, ana ve babasıyla kişisel ve doğrudan ilişki kurma ve sürdürme hakkına sahiptir" kuralı getirilmiştir. Bu kural ile çocuklar, üstlerinde velayet ve kişisel ilişki hakları icra edilen varlıklar olmaktan çıkarılmış, çocukları ebeveynleri ile olan ilişkilerinde hak sahibi ve bunlara karşılık gelen yükümlülüklerin yararlanıcıları olarak gören çağdaş anlayış benimsenmiştir ${ }^{25}$. Bu yeni düzenleme ile birlikte yine çağdaş anlayışı yansıtan çocuğun üstün yararı ilkesi de anne ve baba

21 Bilge Öztan ve Fırat Öztan, 'Boşanmada Velayetin Tevdii' (2016) 1 (2) Çankaya Üniversitesi Hukuk Fakültesi Dergisi 473, 484; Mustafa Dural, Tufan Ögüz ve M Alper Gümüş, Türk Özel Hukuku Cilt III, Aile Hukuku (14. Bası, Filiz Kitabevi 2019) 144; Emine Akyüz, Çocuk Hukuku-Çocukların Hakları ve Korunması, (6. Bası, Pegem Akademi 2018) 231. Türk Medeni Kanunu'nda hâkimlere geniş bir takdir yetkisi tanınmış olsa da hukukumuzda aile içi şiddetin önlenmesine ilişkin düzenlemelerin velayetin ve kişisel ilişkinin düzenlenmesinde şiddet unsurunun dikkate alınmasına ilişkin bir çerçeve çizdiğini ve böylece takdir yetkisinin sınırlarını daralttığını belirtmek gerekir. 6284 sayılı Ailenin Korunması ve Kadına Karşı Şiddetin Önlenmesine Dair Kanun (Kanun Numaras1: 6284, Kabul Tarihi: 08.03.2012, RG 20.03.2012/28239), şiddet uygulayan kişilere ilişkin olarak hâkimin alabileceği önleyici tedbirler arasında velayete ve kişisel ilişkiye ilişkin düzenleme yapmaya yönelik yetkileri de saymıştır ( $\mathrm{m}$ 5/I ç, $\mathrm{m}$ 5/III). Bu yetkiler, şiddet mağdurunun çocuğun kendisi değil, diğer ebeveyn olduğu hallerde de kullanılabilecektir (Mehmet Günay, '6284 Sayılı Kanuna Göre Koruyucu ve Önleyici Tedbirler' (2012) 3 (4) Türkiye Adalet Akademisi Dergisi 650, 666). Böylece kanun koyucu, aile içi şiddetin varlığı halinde, şiddetin devamına olanak sağlayan ilişkilerin kaldırılması için gerekirse velayet ve kişisel ilişkiye ilişkin konularda da karar alınmasını öngörmüş, bu kararlarda şiddet unsurunun, mağduru ister çocuk ister ebeveyn olsun birincil önemde dikkate alınması gerektiğini ortaya koymuştur. Bu kanuni düzenlemenin, çocuğun velayetinin ve kişisel ilişkilerinin düzenlenmesinde genel bir ilke getirdiğinin kabulü gerekir. 6284 sayılı kanun ve dayandığı İstanbul Sözleşmesi’nin izledikleri amacın yerine gelebilmesi için söz konusu ilkenin sadece 6284 sayılı kanun çerçevesinde yapılan talepler çerçevesinde değil, çocuğun velayetinin düzenlenmesini gerektiren diğer hallerde de uygulanması gerekmektedir.

22 İlknur Serdar, 'Birlikte Velayet' (2008) 10 (1) Dokuz Eylül Üniversitesi Hukuk Fakültesi Dergisi 155, 166. TMK'da belirli bazı konularda çocuğun yararının veya menfaatinin esas tutulması gereğini zikreden hükümler bulunmaktadır; velayetin kapsamına ilişkin m 339/I ile kişisel ilişkinin düzenlenmesine ilişkin m 182/II bunlar arasındadır. Hukukumuzda çocuğun yararı kavramına değinen diğer hükümler için Öztan ve Öztan (n 21) 481.

23 Turgut Akıntürk ve Derya Ateş, Türk Medeni Hukuku-Aile Hukuku, İkinci Cilt, (21. Bası, Beta 2019) 311; Bilge Öztan, Aile Hukuku (6. Bası, Turhan Kitabevi 2015) 778-779; Öztan ve Öztan (n 21) 484-485; Hayrünnisa Özdemir ve Ahmet Cemal Ruhi, Çocuk Hukuku (Ders Kitabı) (3. Bası, On İki Levha 2019) 316; Akyüz (n 21) 231. Hukuki metinlerde ve öğretide kullanılan çocuğun yararı, üstün yararı, güvenliği, menfaati terimlerinin içerik bakımından farklılık içermediği yönünde, Gülçin Elçin Grassinger, Türk Medeni Kanununda Yer Alan Velayet Hükümleri Kapsamında Küçüğün Kişi Varlığının Korunması İçin Alınacak Tedbirler (On İki Levha 2009) 57-58.

24 Rona Serozan, Çocuk Hukuku (İkinci basıdan tıpkı bası, Vedat Kitapçılık 2017) 65.

25 Öztan ve Öztan (n 21) 474-475; çocuğun hak süjesi olarak tanınmasına ilişkin olarak, bkz Fulya Erlüle, İsviçre Medeni Kanunu'nda Yapılan Değişiklikler Işı̆̆ı̆nda Boşanmada Birlikte Velayet (Yetkin Yayınları 2019) 48 vd. 
ile ilişkilerde gözetilmesi gereken bir anayasal bir ilke olarak tanınmış olmaktadır. İç hukukumuzun parçası olan ${ }^{26}$ Çocuk Haklarına Dair Sözleşme de yine bu ilkenin hukukumuzda genel bir kural olarak uygulanmasını sağlamaktadı2²7 Çocuk Haklarına Dair Sözleşme'nin 3. maddesinin 1. f1krası uyarınca “Kamusal ya da özel sosyal yardım kuruluşları, mahkemeler, idari makamlar veya yasama organları tarafindan yapılan ve çocukları ilgilendiren bütün faaliyetlerde, çocuğun yararı temel düşüncedir."28 Böylece, bu sözleşme çerçevesinde, çocuğun yararına uygun çözümün bulunması, çocukları ilgilendiren diğer konularda olduğu gibi, velayetin boşanan eşlerden birine bırakılması konusunda da hem kanun koyucunun hem de yargı organının esas almakla yükümlü olduğu temel saik olmaktadır ${ }^{29}$. Birleşmiş Milletler Çocuk Hakları Komitesi, çocuğun üstün yararının birinci planda dikkate alınması hakkına ilişkin 14 numaralı Genel Yorum'da (Genel Yorum) ${ }^{30}$, çocuğun üstün yararı kavramının sözleşme ile tanınmış tüm hakların tam ve etkin biçimde kullanılmasını ve çocuğu bütünsel gelişimini amaçlayan bir ilke olduğunu (4 numaralı paragraf), bu ilkenin çocuğun menfaatinin diğer menfaatlerle eşit düzeyde tutulmamasını, çocuk için en iyi olan çözüme ağırlık verilmesini gerektirdiğini belirtmiştir (39 numaralı paragraf). $\mathrm{Bu}$ çerçevede yine ülkemizin taraf olduğu Avrupa İnsan Hakları Sözleşmesi'nin de çocuğun menfaatinin üstün tutulması konusunda etki doğuran bir uluslararası belge olduğunun altı çizilmelidir. Nitekim her ne kadar sözleşme metninde yer almasa da, Avrupa İnsan Hakları Mahkemesi verdiği kararlarda çocuğun üstün yararını taraf devletlerce hesaba katılması gereken bir değer olarak belirlemiştir ${ }^{31}$.

\footnotetext{
26 Bkz yuk n 3.
}

27 Çocukların korunmasına iliş̧kin diğer uluslararası sözleşmeler için bkz Sevgi Usta, Velayet Hukuku (On İki Levha 2016) 62 vd; Öztan ve Öztan (n 21) 476 vd; Serozan (n 24) 54-59.

28 Serdar (n 22) 168. Çocuk Haklarına Dair Sözleșme'nin doğrudan uygulanabilirliği konusuna ilișkin tartışmalar için, bkz Usta (n 27) 76-80. Temel hak ve özgürlüklere ilişkin uluslararası antlaşmaların içerdikleri kuralların soyut ve programatik niteliği, kanun koyucu tarafından somutlaştırılmadan mahkemelerce doğrudan uygulanabilirliklerini güçleştirmektedir; bu konuda bkz Serozan (n 24) 47 vd. Ancak uygulamada Yargıtay’ın velayete ve kişisel ilişki kurulmasına ilişkin kararlarında Çocuk Haklarına Dair Sözleşme'nin çocuğun yararının öncelikli olmasına ve çocuğun görüşünün alınmasına ilişkin hükümlerini uygulamakta tereddüdü bulunmamaktadır; yakın tarihli örnekler için bkz Yargıtay 2. HD, 4398/12754, 24.12.2019; 2. HD, 2205/258, 16.1.2019; 2. HD, 4268/9711, 20.09.2018, <www.lexpera.com> Erişim Tarihi 11.05.2020.

29 Çocuk Haklarına Dair Sözleşme'nin çocuğun velayeti ve kişisel ilişki kurma hakkı ile ilintili diğer hükümleri arasında, çocuğun kendi üstün yararına aykırı olmadıkça, anne ve babanın ikisiyle de düzenli bir biçimde kişisel ilişki kurma ve doğrudan görüşme hakkını tanıyan 9. maddesinin 3. fikrası, anne ve babasını bilme ve onlar tarafından bakılma hakkını düzenleyen 7. maddesinin birinci fikrası, taraf devletlerin, "çocuğun yetiştirilmesinde ve gelişmesinin sağlanmasinda anababanın birlikte sorumluluk taşıdıkları ilkesinin tanınması için her türlü çabayı" göstereceklerini öngören 18. maddesinin birinci fikrası ile çocuğun karar alma sürecine katılımını düzenleyen 12. maddesi bulunmaktadır.

30 UN Committee on the Rights of the Children, 'Right of the Child to Have His or Her Best Interests Taken as a Primary Consideration' (2013), General Comment No 14, <https://tbinternet.ohchr.org/_layouts/15/treatybodyexternal/Download. aspx?symbolno=CRC\%2fC\%2fGC\%2f14\&Lang=en $>$ Erişim Tarihi 11.05.2020.

31 Bu konuya değinen ilk kararlardan biri, 1994 yılında verilmiş olan Hokkanen v Finlandiya kararıdır. Kararda baba ile çocuk arasında kişisel ilişki kurulmasını kolaylaştırmak için alınması gereken önlemler çerçevesinde zorlama tedbirlere başvurulurken tüm ilgililerin haklarının, özellikle de çocuğun üstün yararının gözetilmesi gerektiği belirtilmiştir; bkz Hokkanen v Finland App no 19823/92 ( ECtHR, 23.09.1994), https://hudoc.echr.coe.int/eng\#\{\%22 itemid\%22:[\%22001-57911\%22]\}, Erişim Tarihi 11.05.2020. Mahkemenin konuya ilişkin ilkelerini açıkladığı yakın tarihli bir kararı için, bkz YI v Russia App no 68868/14 (ECtHR, 25.02.2020), https://hudoc.echr.coe.int/spa\#\{\%22item id\%22:[\%22001-201326\%22]\} Erişim Tarihi 11.05.2020) 
Böylece görülmektedir ki çocuğu ilgilendiren kararların onun üstün yararına uygun biçimde alınması gereği, hukukumuzda hem anayasal düzeyde bağlayıcılık içeren, hem de uluslararası sözleşmeler yoluyla iç hukukumuzun parçası haline gelmiş olan genel nitelikte bir ilkedir. Demek ki yargı organları, velayet konusu da dâhil olmak üzere, çocukları ilgilendiren kararlarda bu ilkeyi temel düşünce olarak almak zorundadırlar. Kullanılacak standardın çocuğun ihtiyaçlarına odaklanmış biçimde belirlenmesi, kendini gereği gibi ifade edemeyen çocuğun bu zayıf durumunun dengelenmesini sağlamaktadır ${ }^{32}$. Nitekim Genel Yorum'da belirtildiği gibi, çocuklar, bağımlılık, olgunluk, hukuki statü açılarından yetişkinlere nazaran eksiklik içindedirler. Kendi menfaatlerini savunma konusunda yetişkinlerden daha az imkâna sahip olmaları çocukların menfaatlerinin altının çizilmesini gerektirmektedir; aksi halde bu menfaatler görünmez hale gelebileceklerdir (37 numaralı paragraf).

Çocukları ilgilendiren tüm alanlarda olduğu gibi, velayete ilişkin kararların da çocuğun üstün yararına göre şekillenmesi gerektiği konusunda herkes hemfikirdir ${ }^{33}$; asıl sorun bu menfaatin nasıl tespit edileceğidir. Çocuğun üstün yararı da tüm belirsiz standartlar gibi hepimizde bir fikir uyandırmakta, ancak somutlaştırılması güçlükler yaratabilmektedir.

Kavramın bu esnek niteliği aslında kullanılmasındaki avantajı ve bu kadar uzun ömürlü olmasını açıklayan temel etmen olarak karşımıza çıkar. Hukuk sistemlerinin bazı konularda bu tür açık uçlu standartları tercih etmelerinin altında, çözüm gerektiren ihtilafın altındaki olguların çok karmaşık ve çeşitli olabileceği hallerde, somut olaya göre verilecek kararın önceden konulan genel kurallara göre yapılan değerlendirmeden daha adil sonuca götüreceği düşüncesi yatmakta ve standardın yarattığı belirsizliğe bu nedenle tahammül edilmektedir ${ }^{34}$. Başka bir deyişle adil çözüm ancak somut faktörlere göre belirlenebiliyorsa bu çözümü bulma görevi, geniş bir standart çerçevesinde hâkime bırakılır. Velayete ilişkin sorunlarda da çocuğun üstün yararı ilkesinin herhangi bir daraltıcı etmen olmaksızın kullanılması bu kabulün bu alanda da geçerli olduğunu göstermektedir. Bu alan özelinde hâkime tanınan geniş takdir yetkisi, tüm çocuklar veya ortalama çocuk için neyin faydalı olduğuna göre değil, belirli bir çocuğun durumuna göre karar verilmesini sağlar ${ }^{35}$;

\footnotetext{
32 Usta (n 27) 137; Evgen Gülçin Elçin, 'Çocuğun Menfaati Gereği Çocukla İlgili Uyuşmazlıklarda Görüşünün Alınmaması Gereken Durumlar' iç Evgen Gülçin Elçin-Arzu Genç Arıdemir (edr), Çocuk Hakları Çalışmaları-I (On İki Levha 2017) 7; Öztan ve Öztan (n 21) 482.

33 Bartlett (n 14) 467. Bu ilkeyi yaygınlaştıran Çocuk Haklarına Dair Sözleşme çok geniş bir coğrafyaya yayılmış biçimde uygulanmaktadır. Sözleşmeyi imzalayan ve onaylayan ülkeler için, bkz <https://treaties.un.org/Pages/ViewDetails. aspx?src=IND\&mtdsg_no=IV-11\&chapter=4\&lang=en $>$, Erişim Tarihi 11.05.2020. Amerika Birleşik Devletleri, sözleşmeyi imzalamış fakat onaylamamıştır. Ancak sözleşme ile benimsenen değerlerin Amerika Birleşik Devletleri yargı organlarınca da benimsenen değerler olduğu belirtilmektedir (Elaine E Sutherland, 'Child Custody and Cognate Concepts: The Challenges' iç Barbara Stark, Jacqueline Heaton (edr), Routledge Handbook of International Family Law (Routledge 2019) 128, dn 3.)

34 Elizabeth S Scott ve Robert E Emery, 'Gender Politics and Child Custody: The Puzzling Persistence of the Best-Interest Standard' (2014) 77 Law and Contemporary Problems 69, 74.

35 Bartlett (n 14) 470; Sutherland (n 33) 134.
} 
böylece sıra dişı durumların ve ihtiyaçların eşik altında kalmasına engel olur. Genel Yorum'da da çocuğun üstün yararı kavramının karmaşıklığına dikkat çekilmiş, ancak erdeminin de esnekliğinde ve ihtiyaçlara göre şekillenebilen dinamik niteliğinde yattığ1 belirtilmiştir: $\mathrm{Bu}$ niteliği sonucu çocuğun üstün yararı kavramı, çocuğun bireysel durumuna göre adapte edilebilen bir karar alma mekanizması sağlamaktadır (32 ve 34 numaralı paragraflar).

Ancak bu esneklik çeşitli sorunları da beraberinde getirmektedir. Çocuğun üstün yararı ilkesinin hâkime verdiği yetkinin genişliği, belirli bir velayet davasında çıkacak sonucu tamamen belirsiz ve öngörülmez kılmaktadır. Sonucun öngörülmezliğinin yarattığı sorunlar içinde en çok dile getirilenler husumet ortamının tırmanması ve ayrımcı çözümlere kapı açılmasıdır ${ }^{36}$. Çocuğun üstün yararı standardı çerçevesinde her iki tarafin da velayeti elde etme ihtimali bulunmaktadır. Böylece her iki taraf da karşı tarafı kötüleyici iddialar geliştirmek ve karşı tarafla iş birliği yapmaktan kaçınmak yönünde cesaret bulmakta, taraflar uzlaşmacı davranışa teşvik edilmemektedir ${ }^{37}$. Husumetin bu şekilde tırmanması ise ebeveynleri ileride çocuğun da zararına olacak şekilde birlikte hareket edemez hale getirmektedir. $\mathrm{Bu}$ ihtilaf ortamı velayet konusunun başka talepleri bertaraf etmek için koz olarak kullanılabilmesi imkânını da doğurmaktadır. Velayet açısından kazanma ihtimali olan ebeveyn, aslında velayeti almak istemese de, bu unsuru kullanarak diğer ebeveyni başka alanlarda taviz vermeye zorlayabilmektedir. Bu durumda çocuğun velayetini almaya en istekli olan tarafın bu uğurda ekonomik taleplerinden vazgeçmesi sonucu doğabilmektedir ${ }^{38}$. Keza çocuğun üstün yararı standardının genişliği, karar organının, velayet sorunu özelinde hâkimin, bilerek veya bilmeyerek kendi önyargılarını bu sürece dâhil etmesine, bireysel inançların kararı etkilemesine olanak sağlamaktadır ${ }^{39}$. $\mathrm{Bu}$ çerçevede anne ile baba konumundaki kişilerin farklı ebeveynlik standartlarına tabi tutulmaları söz konusu olabilmektedir. Ayrıca, esasında toplumdaki cinsiyet ayrımcılığına dayalı olarak gelişen, kadın ve erkek arasında çocuğun bakımı için gerekli imkânlara ulaşma konusundaki eşitsizlik, çocuğun üstün yararı görüntüsü

\footnotetext{
36 Ayrıca, hangi ebeveynin daha iyi bir ebeveyn olduğuna yönelik bir değerlendirmede iddia edilen olguların ispatına ilişkin güçlükler, bu iddiaların manipüle edici etkileri ve kanun yollarının işlevsiz hale gelmesine yönelik çekinceler için bkz Scott ve Emery (n 34) 74 vd; benzer yönde Susan Beth Jacobs, 'The Hidden Gender Bias Behind the Best Interest of the Child Standard in Custody Decisions' (1997) 13 Georgia State University Law Review 845, 855; Dekeuwer-Defossez (n 13 ) 349. Bunun yanı sıra hâkimlerin destek aldıkları uzman personelin çocuğun üstün yararını doğru biçimde saptamaya muktedir olup olmadıkları da tartışma konusudur. Bir görüşe göre değerlendirmenin disiplinler arası bir ekiple yapılması gerekir; bkz Büchler ve Vetterli (n 18) 244; Genel Yorum (94 numaralı paragraf). Ancak, kısa süreli temaslarda gerçek ailevi durumun anlaşılamaması riskinin hâkim için olduğu kadar bu kişiler için de mevcut olduğu ve uzman görüşüne başvurulurken de ölçülü biçimde davranılması, özellikle uzman görüşünün velayetin kimde olması gerektiğine ilişkin çıkarsama içermemesi gerektiği yönünde, bkz Scott ve Emery (n 34) 94.

37 Scott ve Emery (n 34) 69, 72; Bartlett (n 14) 470; Sutherland (n 33) 134.

38 Bartlett (n 14) 470. Velayeti alma tehdidinin, aslında velayeti almaya istekli olmayan tarafça nafaka yükümlülüğünü azaltmak için koz olarak kullanıldığı yönünde, Kay (n 17) 34; Schwarz (n 15) 383. Bu yazarlara göre ekonomik açıdan kadınların zararına çalıșan ve çocukla yakın olmak için ekonomik taleplerden vazgeçmeye zorlayan bu kural, kadınlara karşı ayrımcılık yaratmaktadır.

39 Kathy T Graham, 'How the ALI Child Custody Principles Help Eliminate Gender and Sexual Orientation Bias from Child Custody Determinations' (2001) 8 (1) Duke Journal of Gender Law 323, 325.
} 
altında cinsiyet ayrımına dayalı veya bu ayrımı perçinleyen kararların alınmasına yol açabilmektedir ${ }^{40}$. Örneğin, taraflardan hangisinin ekonomik kaynaklarının daha fazla ve istikrarlı olduğuna dayalı bir değerlendirme, kadının daha az kaynağa sahip olmasının evlilik sırasındaki iş bölümünün sonucu olabileceğinin hesaba katılmaması anlamına gelir ${ }^{41}$. Benzer şekilde, kimin çocukla daha çok vakit geçirebileceğine dayalı bir değerlendirme, çalışan anneleri çalışan babalar karşısında dezavantajlı duruma sokabilir; nitekim çalışan annelerin yetkinliği geleneksel anne modeline göre, çalışan babaların yetkinliği de geleneksel baba modeline göre ölçülmektedir ${ }^{42}$.

$\mathrm{Bu}$ eleştiriler çerçevesinde velayete ilişkin uyuşmazlıklarda çocuğun üstün yararı kavramının içeriğinin öngörülebilir biçimde belirlenmesinin mümkün olup olmadığı ve bu tür belirlemelerin kavramdan beklenen faydaları ne şekilde etkileyeceği sorusu karşımıza çıkmaktadır. Hukuk sistemlerindeki gelişmelere bakıldığında çocuğun üstün yararı kavramını öngörülebilir hale getirme ihtiyacının öteden beri kuvvetle hissedildiği ve bunun çocuğun üstün yararı değerlendirilirken bazı etmenlerin özellikle ön plana çıkmasına neden olduğu görülmektedir. Bazı sistemlerde annenin çocuk bakımında oynadığı rol halen birincil önemde sayılmakta ve çocuğun üstün yararının anne ile kalmasında olduğu karine olarak kabul edilmektedir ${ }^{43}$. Bununla beraber velayet hukukunda gittikçe daha yaygın olarak benimsenen eğilimlerden biri, çocuğun her iki ebeveynle de ilişkisinde devamlılığın sağlanmasıdır ${ }^{44}$. Bu yaklaşım anne ayrıcalığının kııılmasına ve ortak velayete ilişkin karine niteliğinde çözümlerin yaygınlaşmasına neden olmuştur ${ }^{45}$. Bunlara ilaveten, anne gruplarının aile içi şiddete ve baba gruplarının çocukların anneler tarafından babalarına yabancılaştırılmalarına yaptıkları vurgular ilgili tehlikeyi yaratan ebeveyne velayetin verilmemesinin de velayet hukukunun temel politikaları arasında yer alması sonucunu doğurmuştur ${ }^{46}$.

Böylece çocuğun üstün yararının saptanmasında belirlilik ve öngörülebilirlik sağlamak üzere, çocuğun üstün yararına hizmet ettiği düşünülen çözümlerin bazen kanun koyucu tarafından genel kural olarak benimsendiği, bazen de yargı organları tarafından fiilen genel kural olarak uygulandığg görülmektedir. Bu noktada dikkat çeken hususlardan biri, birbirleriyle çelişkili sonuçlara götüren bu kuralların tamamının çocuğun üstün yararı kavramı üzerine kurulu olmalarıdır. Bu durum, çocuğun üstün yararına ilişkin mevcut ampirik çalışmaların yetersizliğini ortaya koymakta, bu çalışmaların farklı toplumlar ve özellikle farklı toplumsal katmanlar

\footnotetext{
Jacobs (n 36) 849, 857.

41 ibid 857-858.

42 Geleneksel baba modelinde babaların gündelik işlere katılmasının beklenmediği, böylece babanın ev işlerine katılımla ilgili en ufak çabasının önemli bir adım olarak görüldüğü yönünde, ibid 867.

43 Bkz aş II A 1.

44 Scott ve Emery (n 34) 83; Sutherland (n 33) 134; Caulley (n 13) 448.

45 Sutherland (n 33) 135.

46 Susan B Boyd, 'Can Child Custody Law Move Beyond the Politics of Gender' (2000) 49 University of New Brunswick Law Journal 157, 158 vd; Scott ve Emery (n 34) 70- 71.
} 
ve gelir düzeyleri üzerinden çeşitlendirilmesi gerektiğini düşündürmektedir ${ }^{47}$. Konumuz açısından öncelikli olan mesele ise bu kuralların anne ve baba arasındaki eşitliğin sağlanması açısından ne anlama geldikleri, daha genel bir sorun olan kadınerkek eşitliği kavramı altında nerede durduklarıdır. Bu açıdan da çocuğun üstün yararı standardını öngörülebilir hale getirme çabalarının ilginç sonuçlar doğurduğu söylenebilir. Nitekim çocuğun üstün yararı standardının öngörülmezliğinin sakıncalarından biri ayrımcılığa kapı açması iken, aşağıda açıklanacağı gibi, öngörülebilirlik sağlayan kuralların bazıları ayrımcılığı daha da derinleştirici rol oynamaktadırlar. Başka bir deyişle, bazı kurallar ayrımcılığı risk olmaktan çıkarıp doğrudan doğruya öngörülebilir bir sonuç haline getirmektedirler.

\section{Velayetin Düzenlenmesinde Çocuğun Üstün Yararının Belirlenmesine İlişskin Ölçütler}

Çocuğun üstün yararının belirlenmesine ilişkin uygulanmış ve uygulanmakta olan sistemlerin iki ana grup altında toplanmaları mümkündür. Bazı sistemler, velayetin tek başına kullanılması esasına dayanmakta olup, çocuğun hangi ebeveyn ile hayatını devam ettirmesinin onun üstün yararına daha uygun bir çözüm teşkil ettiğine ilişkin kurallar geliştirmişlerdir. Bazı sistemlerde ise çocuğun üstün yararının boşanma sonrasında da velayetin birlikte icra edilmesinden geçtiği kabul edilmiştir; ancak bu noktada velayetin "birlikte" icrasının ne anlama geldiği konusunda önemli ayrımlar bulunmaktadır.

\section{A. Tek Başına Velayet}

\section{Anne Şefkatine Muhtaç Olma Ölçütü}

Küçük yaştaki çocukların “anne şefkatine muhtaç” oldukları yönündeki düşünce, velayet konusunda önceliğin anneye verilmesini sağlamaktadır (tender years doctrine $)^{48}$. Anne ile küçük yaştaki çocuk arasında özel bir bağ olduğuna ve annenin “doğal olarak” çocuğun bakımı ile yükümlü ve yetkili olduğu varsayımına dayalı olan bu düşünce, 20. yüzyılın başlarında yaygınlık kazanmaya başlamış ve çocuklar üzerindeki haklarda önceliği babaya veren önceki kuraldan kopuş sağlamıştır ${ }^{49}$. Böylece velayet düzenlemesinde babayı tercih eden bir sistemden anneyi tercih eden bir sisteme geçiş gerçekleşmiştir.

\footnotetext{
47 Amerika Birleşik Devletleri’nde ebeveynlik ilişkilerine ilişkin hukuk kurallarının farklı sosyal ve kültürel sınıflar açısından taşıdığı anlam ve doğurduğu sonuçlar üzerine bir inceleme için, bkz June Carbone ve Naomi Cahn, 'The Triple System of Family Law' (2013) Michigan State Law Review 1185.

48 Graham (n 39) 324; Sutherland (n 33) 135.

49 İsviçre için bkz Büchler ve Vetterli (n 18) 239; Anglosakson hukuk sistemi için bkz Lynn Dennis Wardle, William C Duncan ve Laurence C Nolan, 'United States of America' iç Walter Pintens (ed) International Encyclopaedia of Laws: Family and Succession Law (Wolters Kluwer 2018) 184; Darya Hakimpour, 'Distributing Children as Property: The Best Interest of the Children or the Best Interest of the Parents' (2017) 37 (1) Children's Legal Rights Journal 128, 130; Jacqueline W Yee, 'Child Custody Decisions: Should the Best Interests of the Child Standard Be the Primary Determinant' (2019) 65 (1) Wayne Law Review 175, 177; James Herbie DiFonzo,'Dilemmas of Shared Parenting in the 21st Century: How Law and Culture Shape Child Custody' (2015) 43 (4) Hofstra Law Review 1003, 1004-1006, Caulley (n 13) 413.
} 
Anglosakson hukuk sistemlerinde bu kuralın öncelikle başlı başına bir velayet hukuku kuralı olarak uygulandığı görülmektedir ${ }^{50}$. Ancak toplumsal cinsiyet eşitliği söylemi ve baba hareketlerinin büyümesi bu doktrini zayıflatmış ve anne ve baba, velayeti alma konusunda eşit adaylar olarak görülmeye başlanmıştır ${ }^{51}$. Böylece anne şefkatine muhtaç olma ölçütü resmî bir kural olmaktan çıkmış, yerini cinsiyet açısından tarafsız görünen kurallara bırakmıştır ${ }^{52}$. Bunlardan en kalıcı ve yaygın olanı da $\mathrm{da}^{53}$ çocuğun üstün yararı (best interest) ilkesi olmuştur ${ }^{54}$.

Bununla beraber, başta da ifade edildiği gibi, cinsiyet açısından tarafsız görülen bu kuralın esnekliği, kanun koyucuların ortadan kaldırır gibi göründükleri ayrımların yargısal yorum yoluyla geri dönmesini sağlayabilmektedir. Nitekim anne şefkatine muhtaç olma ölçütünün terk edildiği sistemlerde çocuğun üstün yararı ilkesine geçişin velayetin anneye verilmesi yönündeki tercihi ortadan kaldırmadığı gözlemlenmiştir. Anne şefkatine muhtaç olma ölçütü, çocuğun üstün yararı kavramının içeriğinin daraltılmasını ve yarg1 kararlarında öngörülebilir bir örüntü yaratılmasını sağlamakta, velayetin öncelikli olarak anneye verilmesinin gerekçelendirilmesi işlevini görmektedir ${ }^{55}$. Aşağıda göreceğimiz gibi, Yargıtay da velayete ilişkin uyuşmazlıklarda çocuğun üstün yararı ilkesinin yorumlanmasında esas olarak bu ölçütü kullanmaktadır ${ }^{56}$.

Çocuğun yararının tespit edilmesinde anne şefkatine muhtaç olma ölçütünün bir karine gibi uygulanmasının çocuğun yararına ilişkin olarak yaratabileceği temel sakınca, bunun babanın çocuğun hayatında hiçbir söz sahibi olmamasına ve çocuğun babasına yabancılaşmasına neden olabilecek olmasıdır. Ancak bu sakınca velayetin eşlerden birine verildiği hallerin tümü için geçerlidir. Ebeveynlerin saygı gösterecekleri, genişletilmiş bir kişisel ilişki hakkının kurulması ile çocuğun hayatında istikrar sağlanması ve babadan uzaklaşma riskinin asgariye indirilmesi

$\overline{50}$ Hakimpour (n 49) 131-132.

51 Amerika Birleşik Devletleri’nde kuralın terkedilmesinin nedenleri için bkz Wardle, Duncan ve Nolan (n 49) 185.

52 Wardle, Duncan ve Nolan (n 49) 127.

53 Bu kuralın yerine geçen kavramlardan biri de birincil bakıcı ölçütüdür; ancak bu kavram çocuğun üstün yararı kavramından daha az cazip görülmüştür; bkz aş II A 2 .

54 Jacobs (n 36) 853; Graham (n 39) 324; Wardle, Duncan ve Nolan (n 49) 126.

55 Amerika Birleşik Devletleri’nde eyaletlerin çoğunun çocuğun üstün yararı ilkesini uyguladığı, ancak araştırmaların annenin çocuğa bakım ve duygusal destek sağlamada ideal ebeveyn olduğu varsayımına dayalı anne şefkati öğretisinin çocuğun üstün yararı ilkesinin uygulanmasını etkilediği yönünde, Yee (n 49) 179; DiFonzo (n 49) 1007; ayrıca bkz Caulley (n 13) 417-418.

56 Bkz aş III B. İsviçre hukukunda da 1990'lara kadar bu görüşün öncelikli olduğu görülmektedir; anneye öncelik verilmesi yönündeki federal mahkeme kararlarına örnekler için bkz BGE 111 II 225; BGE 109 II 193, kararlar için <https://www.bger. ch/index.htm> Erişim Tarihi 11.05.2020. Daha sonraları cinsiyete dayalı bir avantaj sağlanmaması için bakım ilişkisinin devamlılığına dayanan birincil bakıcı ölçütüne göre çocuğun yararının yorumlandığı belirtilmektedir (Büchler ve Vetterli (n 18) 239). Ortak velayetin kural şekline büründüğü yasal değişiklikten önce, çocuğun yüksek menfaatine göre tek başına velayete karar verilmesini gerektiren İsviçre sisteminde annenin kendiliğinden öncelik sahibi olmadığını açıkça ifade eden bir karar için, bkz BGer 5A_375/2008, 11.08.2008, para 3.1.4, <http://relevancy.bger.ch/php/aza/http/index.php?highlight_ docid=aza\%3A\%2F\%2F11-08-2008-5A_375-2008\&lang=de\&type=show_document $>$ Erişim Tarihi 11.05.2020. 
mümkündür ${ }^{57}$. Dolayısıyla çocuğun menfaati açısından uygun olup olmadığına bakıldığında, genişletilmiş bir kişisel ilişki ile birleşmiş bir anne şefkatine muhtaç olma ölçütünün, çocuğun ilişkilerdeki devamlılık yönündeki ihtiyacına cevap verebilecek nitelikte olduğu savunulabilir. Anne şefkatine muhtaç olma ölçütü esasında çocuğun menfaatlerinden ziyade anne ve babaların menfaatlerini korumada yetersiz kaldığı gerekçesiyle eleştirilmiştir. Bu kuralın olayların büyük çoğunluğunda velayetin anneye verilmesini sağladığı iddiasında olan baba grupları açısından bu durum -ve fiilen bu sonuca götürdüğü hallerde çocuğun üstün yararı ölçütübabanın çocuğun hayatından hem hukuki hem de duygusal olarak çıkmasına neden olmaktadır ve bu yönüyle cinsiyet eşitliğine aykırı görünmektedir. Duruma anneler açısından bakıldığında da esasında bu ölçütün yarattığı fiilî üstünlüğün son derece kırılgan olduğunu söyleyebiliriz. Nitekim çocuğun anne şefkatine muhtaç olması nedeniyle anneye birakılması kuralı, ancak belirli bir olaydaki anne, geleneksel anne modeline uygun olduğu hallerde kadını koruyucu işlev görmektedir. Sistemin anne lehine yarattığı avantaj, annenin çocuğun velayetini üstlenmeye uygun olmadığının düşünüldüğü hallerde kolaylıkla ortadan kalkmaktadır. Özellikle annenin çalıştığ için çocuğa bakamayacağı düşüncesi veya yaşam tarzına dayalı ahlaki mülahazalar kuralın uygulanmasına engel olabilmektedir ${ }^{58}$. Ayrıca çocukların anne şefkatine muhtaç olduğu yönündeki anlayışın, ortak çocuklardan kadınların sorumlu olduğu ve erkeklerin sorumlu olmadığı yönündeki yerleşik inancı güçlendirdiğ ${ }^{59}$ ve bu durumun anne ve babaya toplumun yönelttiği beklentilerdeki farklılıkların muhafaza edilmesine hizmet ettiği de söylenebilir. Bu ise yine annenin geleneksel, evde oturan anne modelinden ayrılması halinde velayeti icra etmeye uygun olmadığ inancina götürebilecek ve velayetin kendisine verilmemesine sebep olabilecektir. Görüldüğü gibi anne şefkatine muhtaç olma ölçütü, bir karine biçiminde uygulandığında bir yandan babaların çocuğun gelişiminde üstlenebilecekleri işlevi göz ardı ederek erkekleri belirli bir rol içine sıkıştırmakta, öte yandan anneleri de ancak geleneksel kalıplara uygun davrandıkları ölçüde korumakta, dolayısıyla yerleşik cinsiyet rollerini perçinleyici işlev görmektedir.

\section{Birincil Bakıcı Ölçütü}

80'li yıllarda bazı Amerikan eyaletlerinde ortaya çıkmış başka bir kural ise, velayeti icra etmeye uygun olmadığı ispatlanmadı̆̆ı sürece, velayetin çocuğun bakımını geçmişte sağlamış olan ebeveyne, başka bir ifadeyle birincil bakıcıya (primary caretaker) verilmesi yönündedir ${ }^{60}$. Bu kural da yerini çocuğun üstün yararı ölçütüne

\footnotetext{
57 Bu varsayımın ikna ediciliğinin, kişisel ilişkinin düzenlenme biçimine göre bir sistemden diğerine değişebileceğinin altını çizmek gerekir. Örneğin hukukumuzda kişisel ilişki ebeveyne çocukla fiziksel olarak temas kurma dışında hiçbir yetki tanımazken İsviçre Medeni Kanunu'nun 275a maddesi velayet hakkına sahip olmayan ebeveynin bilgi alma hakkını, çocuğun gelişimini etkileyecek kararlardan önce dinlenilme hakkını, çocukla ilgili olarak üçüncü kişilerden bilgi alma hakkını düzenlemektedir.

58 Schwarz (n 15) 383; Graham (n 39) 324; Boyd (n 46) 163.

$59 \quad$ Schwarz (n 15) 383.

60 Sutherland (n 33) 135; Bartlett (n 14) 473.
} 
bırakmış olsa da halen çocuğun yararının saptanmasında dikkate alınan etmenlerden biri olarak karşımıza çıkmaktadır ${ }^{61}$.

Bu kural, çocuğun bakımını öncelikli olarak gerçekleştirmiş kişinin çocukla daha yakın bir bağının olduğu ve ebeveynlik yetisinin daha gelişmiş olduğu varsayımına dayanır ve hâkimin ebeveynlerden hangisinin geçmişte çocukla daha fazla vakit geçirdiğini saptamasını gerektirir ${ }^{62}$. Birincil bakıcı ölçütü de bir karine gibi uygulandığg hallerde çocuğun yararının saptanmasında öngörülebilir bir çözüm getirmekte ve ihtilaf alanını daraltmaktadır ${ }^{63}$. Çocuğun velayetinin ona daha çok ilgi gösteren ebeveyne verilmesini sağladığı için, tek başına velayetin benimsendiği hallerle sınırlı olarak, çocuğun hayatındaki istikrarın korunmasına değer verdiği ve bu açıdan onun yararını korumaya yöneldiği söylenebilir. Ayrıca velayetin tayininde cinsiyete dayalı bir ayrım yapmadığından ve sadece geçmiş ilişki pratiğine odaklandığından ebeveynlere çocuğun velayetini alma konusunda eşit olanak sağlamakta ${ }^{64}$ ve anne şefkatine muhtaç olma ölçütünden farklı olarak belirli bir cinsiyete mensup kişiyi cinsiyeti nedeniyle avantajlı hale getirmemektedir. Birincil bakıcıya öncelik verilmesi, bir yandan evlilik içinde çocuğun bakımına katkı sağlamak açısından her iki ebeveyni de cesaretlendirici olmakta, öte yandan çocuğun üstün yararının cinsiyet ayrımcılığını tetikleyebilecek gelir dengesizliği, iş güvenliği, hayat tarzı seçimleri gibi unsurların devre dışı kalmasıyla belirlenmesini sağlamaktadır ${ }^{65}$. Bu nedenle bu kuralın tek başına velayetin benimsendiği hallerde cinsiyet eşitliği ilkesine en uygun çözüm olduğu söylenebilir. Ancak toplumsal yaşamda, evde bakım yükümlülüğünü gerçekleştirenler çoğunlukla anneler olduğundan, bu kuralın da fiilen annelere öncelik tanınması sonucunu doğurduğu açıktır ${ }^{66}$. Buna istinaden kuralın örtülü biçimde anneleri koruyucu bir kural olduğu söylenmektedir ${ }^{67}$. Bununla beraber bu durum annelerin cinsiyete dayalı olarak değil, kadınların çocuk bakımında birincil rolü üstlenmiş veya buna itilmiş olmalarının sonucu olarak karşımıza çıkmakta ${ }^{68}$, uygulanan kuralın kadınlar lehine bir önyargı tesis ettiği anlamına gelmemektedir ${ }^{69}$.

Ancak bu kural da kendine has sorunlar içermektedir. Velayetin birincil bakıcıya verilmesi, her ailede ebeveynlerden birinin birincil bakıcı olduğu veya olması gerektiği

\footnotetext{
${ }_{11}$ Caulley (n 13) 416. Birincil bakıcı ölçütü, Batı Virjinya eyaletinde bağımsız bir velayet kuralı olarak kabul edilmiş ancak daha sonra aşağıda göreceğimiz ALI İlkeleri'nin önerdiği model ile değiştirilmiştir. Bugün ise bazı eyaletlerde çocuğun velayetinin düzenlenmesinde dikkate alınan etmenlerden biri olarak kullanılmaktadır (Wardle, Duncan ve Nolan (n 49) 186; DiFonzo (n 49) 1007).

62 Bartlett (n 14) 473; Jacobs (n 36) 826; Hakimpour (n 49) 133; Wardle, Duncan ve Nolan (n 49) 186; Caulley (n 13) 414415.

63 Caulley (n 13) 415.

64 Jacobs (n 36) 826.

65 ibid.

66 Wardle, Duncan ve Nolan (n 49) 186; Caulley (n 13) 416.

67 Sutherland (n 33) 135; Scott ve Emery (n 34) 81; Hakimpour (n 49) 133.

68 Wardle, Duncan ve Nolan (n 49) 185.

69 Bartlett (n 14) 473.
} 
varsayımına dayanmaktadır. Ebeveynler arasında bu tür bir ayrımın yapılamayacağı aile tiplerinde bu kural işlememektedir. Örneğin eşlerin çocuğun bakımına aşağ yukarı eşit katkıda bulunduğu, bir bakıcının veya diğer aile fertlerinin yardımına başvurulduğu hallerde bu kural somut duruma adapte olmakta başarısız olmaktadır. ${ }^{70}$ Ayrıca kural, tek başına velayeti esas aldığından, eşler arasında bakımı üstlenme açısından küçük farklılıklar velayetin tayininde büyük farklılıklara yol açmaktadır; bu da hem adaletsiz sonuçlara götürebilecek hem de ihtilafı tetikleyebilecek bir etmendir.

\section{B. Ortak Velayet}

\section{Ortak Velayet Kavramı}

Ülkemizde de son yıllarda sıklıkla gündeme gelmeye başlamış olan ortak velayet kavramı, hem çocuğun yararı açısından, hem de kadın-erkek eşitliği açısından doyurucu bir çözüm olarak düşünülmekte ve pek çok hukuk sisteminde kabul görmektedir. Bir zamanlar çocuğun yararına uygun olmadığı gerekçesiyle kategorik olarak reddedilen ortak velayet ${ }^{71}$, artık olası seçeneklerden biri olmanın da ötesinde, çocuğun yararına en uygun çözüm olduğu varsayımıyla norm haline gelmiştir. Öyle ki artık bazı hukuk sistemleri boşanmanın velayete etkisinin olmayacağını kural olarak kabul etmiş ve tek başına velayeti istisna olarak benimsemişlerdir. Anne ve babanın boşanmadan sonra velayeti birlikte icra etmeye devam etmelerinin temel gerekçesi olarak çocuğun ebeveynlerle olan ilişkilerinde devamlılığın sağlanmasına ilişkin yararı ileri sürülmektedir. Ortak velayet modelinin çocuğun üstün yararına uygunluğu, her bir ebeveynin çocuğun gelişimine kendi biçimleriyle katkıda bulundukları ve çocuk için eşit derecede önemli oldukları ana fikrine dayandırılmaktadır. Ayrıca ortak velayet genel kural olarak benimsendiğinde, muğlak üstün yarar ölçütünü belirli ve öngörülebilir hale getiren bir işlev de görmektedir. Öte yandan ortak velayet, eşitlikçi bir çözüm olduğu gerekçesiyle de kabul görmektedir. Bu görüş çerçevesinde ortak velayet halinde anne ve baba eşit sorumluluklar yüklenmekte ve haklarla donatılmakta, ebeveynlerden birinin çocuğun hayatı üzerinde söz sahibi olma imkânı elinden alınmamış olmaktadır. Eğer çocuğun bakımı da ebeveynler arasında paylaştırılıyorsa, ortak velayet boşanmış babaların çocuktan uzaklaşması

70 ibid 475 .

71 Amerika Birleşik Devletleri'nde 70'li yıllara kadar hâkimler ebeveynlerin ortak talebi olsa dahi ortak velayet taleplerini reddetmişlerdir. O zamanlar bu durum çocuğun bir kişinin yönettiği tek bir evde olmanın vereceği istikrara ihtiyaç duyduğu, çocuğu bir ebeveynden diğerine sürüklemenin ona bir kavganın merkezinde bulunduğunu sürekli olarak hatırlatacağı ve kalıcı hasar vereceği varsayımına dayandırılmıştır (DiFonzo (n 49)1008). İsviçre'de aşağıda göreceğimiz yasal değişikliklerden önce, Federal Mahkeme boşanmış ebeveynler bu konuda anlaşmış olsalar da ortak velayete karar verilemeyeceği, kanun koyucunun tek başına velayeti çocuğun üstün yararına ilişkin bir varsayıma dayalı olarak tesis ettiği ve bu durumu da ancak kanun koyucunun değiștirebileceği yönünde kararlar vermiştir (BGE 117 II 523 ; BGE 123 III 445 ; $<$ https://www.bger.ch/index.htm> Erişim Tarihi 11.05.2020). Fransız temyiz mahkemesi de Fransız hukukundaki aşağıda değinilecek değişikliklerden önce verdiği bir kararda, ebeveynlerin çocuğun on beş günlük sürelerle her birinin evinde kalmasına ilişkin anlaşmalarının çocuğun hayatındaki istikrarı zedelediği için onaylanmaması gerektiği yönünde hüküm kurmuştur (Cass Civ 2, 21.03.1983, 82-11742, <https://www.legifrance.gouv.fr/> Erişim Tarihi 11.05.2020) 
riskini azalttığ 1 gibi boşanmış annelerin üzerindeki aşırı bakım yükünü hafifleten ve çalışmalarına imkân sağlayarak boşanma sonrası fakirleşmeyi de engelleyen bir sosyal-hukuki mühendislik aracı görünümüne bürünmektedir ${ }^{72}$. Böylece, ileri sürülen bu argümanlar çerçevesinde, ortak velayet ile velayet hukukunda birincil amaç olan çocuğun üstün yararına uygun çözüm sağlandığı gibi buna nazaran ikincil nitelikteki eşitlik amacına da ulaşılmış olduğu düşünülmektedir.

Her ne kadar öncelikli olarak çocuğun üstün yararına dayalı gibi görünse de $^{73}$, boşanmada ortak velayet düşüncesinin ne zaman, kimler tarafından ortaya atıldığına ilişkin araştırmalar, buradaki gelişimin de çocuğun yararından ziyade bir cinsiyetler çatışmasına dayalı olarak ortaya çıktığını ve korunan menfaatin asli olarak babaların menfaatleri olduğunu göstermektedir. Ortak velayet yönündeki talepler, çocuğun üstün yararının anne şefkatine muhtaç olma ölçütü çerçevesinde yorumlandığı, velayetin çoğunlukla annelere verilmesine neden olan uygulamaya tepki olarak, bir yandan çocuğun yararı, öte yandan cinsiyet eşitliği argümanları çerçevesinde, çoğunlukla babalar tarafindan geliştirilmiştir ${ }^{74}$. Başka bir deyişle bu noktada cinsiyet eşitliği talebi alışılanın aksine kadınlardan çok, büyük ölçüde erkeklerden gelmiştir ${ }^{75}$. Nitekim aile içindeki görev dağılımına bakıldığında, boşanma aşamasında babaların kendilerini annelerden daha avantajlı kılabilecek bir tek başına velayet modelini kabul ettirmeleri zordur, hâlbuki ortak velayet geleneksel olarak annelere ait görülen bir alanda babalara yer açmakta ve çocuğun hayatının yönetilmesinde eşitlik sağlamaktadır. Bu eşitliğin çocuğun bakımına da yansıması durumunda iştirak nafakasını azaltıcı etkiye sahip olması da baba grupları açısından ortak velayetin cazibesini arttırmaktadır ${ }^{76}$.

\footnotetext{
Denyse Côté, 'La garde partagée des enfants: nouvelles solidarités parentales ou renouveau patriarcal ?' (2004) 23 (3) Nouvelles Questions Féministes 80, 81.

73 Çocuk gelişimi açıcından ortak velayeti olumlu veya olumsuz gören görüşlerin özeti için, bkz Nurten İnce, 'Karşılaştırmalı Hukukta ve Türk Hukukunda Evlilik Birliğinin Boşanma İle Sona Ermesi Durumunda Birlikte Velâyet' (2018) 9 (4) Türkiye Adalet Akademisi Dergisi 189, 196-200; Erlüle (n 25) 114 vd. Türkiye açısından ortak velayet tecrübesi henüz çok yeni olduğundan tecrübelerin aktarımına dayalı ampirik çalışma şartları oluşmamıştır. Boşanan ebeveynlerin hipotetik olarak tercihlerinin sorgulandığı bir araştırma için, bkz Müge Kiremitçi Öztürk, 'Boşanma Sürecinde Ortak (Müşterek) Velayet ve Toplumsal Bakış Açısı', iç Evgen Gülçin Elçin-Arzu Genç Arıdemir (edr), Çocuk Hakları Çalışmaları-I (On İki Levha 2017) 59 vd. Almanya açısından, bu konudaki ampirik çalışmaların tatmin edici sonuçlar vermediği yönünde, Kerima Kostka, 'Elterliche Sorge und Umgang bei Trennung und Scheidung - unter besonderer Berücksichtigung der Perspektive des Kindes' (2005) Familie Partnerschaft Recht 89, 91.

74 Boyd (n 46) 158.

75 Scott ve Emery (n 34) 70; Kay (n 17) 36; Boyd (n 46) 162; Fransa için bkz Dekeuwer-Defossez (n 13) 351.

76 Scott ve Emery (n 34) 77. Baba haklarını savunan grupların ortak velayete ilişkin söylemlerinde çocuk ile birlikte oturmayan babanın çocuğun bakımına katkı sağlamasının bir sorun olarak tanıtıldığının görüldüğü yönünde, Boyd (n 46) 162; hukuk sisteminin çocukla fiilen geçirilen zaman ile iştirak nafakası miktarı arasında bağlantı kurduğu hallerde, bazı ebeveynlerin çocukla daha fazla zaman geçirme taleplerinin saikleri üzerinde soru işaretlerinin doğduğu yönünde, Sutherland (n 33) 137.
} 
Ortak velayet, kural olarak anne ve babanın velayeti eşit yetkilerle ve aralarında uzlaşarak kullanmaları anlamına gelmektedir ${ }^{77}$. Bununla beraber, boşanan eşlerin yaşam alanlarının ayrılması, velayetin içeriğine dâhil sayılan yetkilerin tamamının beraberce kullanılmasında pratik imkânsızlıklara yol açar. Bu nedenle ortak velayet, velayet kavramı içinde bir parçalanmaya götürür. Ortak velayet modelini benimseyen hukuk sistemleri, çocukla ilgili önemli kararların alınması yetkisi ile çocuğun günlük bakımını gerçekleştirmeye yönelen çocuğun himayesini ve bunun gerektirdiği işler için karar alma yetkisini birbirinden ayırma ${ }^{78}$ yoluna gitmişlerdir ${ }^{79}$. Böylece ortak velayet, ayrıntıları itibariyle bir sistemden diğerine farklılık gösterebilse de, ana hatlarıyla ebeveynlerin çocukla ilgili “önemli” konularda birlikte karar almalarına hasredilmiş bir model olarak karşımıza çıkmaktadır ${ }^{80}$. Çocuğun himayesine dayalı yetkilerin kimin tarafından kullanılacağı ve dolayısıyla çocuğun günlük bakımının kimin tarafindan gerçekleştirileceği ise ortak velayetin kabul edildiği hallerde karşımıza çıkan ilave bir sorundur. Bu konuda çocuğun dönüşümlü olarak her bir ebeveynin evinde yaşaması, sürekli olarak tek bir ebeveynde yaşaması veya çocuğun sabit bir yerleşim yerinde kalması ve ebeveynlerin dönüşümlü olarak bu evde yaşaması uygulanma ihtimali olan seçeneklerdir ${ }^{81}$. Eşler arasında bakım yükümlülüğü açısından tam bir eşitlik sağlayacağı düşünülen, çocuğun bir evden diğerine gittiği dönüşümlü himaye modeli, henüz ortak velayet kadar çekici hale gelmemiş olsa da gittikçe artan biçimde gündeme gelmektedir. Avrupa Konseyi Parlamenter Meclisi'nin 2079 sayılı Eşitlik ve Paylaşılmış Ebeveyn Sorumluluğu: Babaların Rolü isimli kararında da üye devletlere ebeveynlerin ayrılması sonrasında çocuğun ebeveynleri ile dönüşümlü olarak yaşaması ilkesini benimsemeleri yönünde çağrı yapılmıştır (principle of shared residence) $)^{82}$.

Anne ve babanın sadece önemli kararları birlikte aldığı, çocuğun himayesine ilişkin yetkilerin ise genellikle görüldüğü üzere anneye bırakıldığı hallerde velayetin birlikte icrası, ileride daha ayrıntılı olarak ele alacağımız üzere, dayandığ

\footnotetext{
Leyla Müjde Kurt, 'Boşanma Durumunda Birlikte (Ortak) Velâyet' (2018) 9 (2) İnönü Üniversitesi Hukuk Fakültesi Dergisi 157, 158; benzer tanımlar için bkz Eylem Apaydın, 'Ortak Hayata Son Verilmesi Sonrası Ortak Velayet Hususunda Yasal Düzenleme Gereği' (2018) 9(1) İnönü Üniversitesi Hukuk Fakültesi Dergisi 445, 447; Serdar (n 22) 162; İnce (n 73) 195; Özdemir ve Ruhi (n 23) 298; hukukumuzda velayetin bir bütün olarak verilmesi gerektiği yönünde, Öztan ve Öztan (n 21) 485. Ancak bazı hukuk sistemleri, ortak velayet halinde bazı yetkilerin paylaştırılarak kullanılmasını kabul ederler. Almanya örneği için bkz Heike Hennemann, 'BGB § 1671' iç Dieter Schwab, Münchener Kommentar zum BGB, Band 10 (8. Bas1, C H Beck 2020) para 20.

78 İsviçre hukukunda ortak velayete ilișkin yeni düzenlemeler 1şı̆̆ında çocuğun himayesi (Obhut/garde) kavramı yeni bir anlam kazanmıştır, bu konuda bkz aş II B 2 a. Amerikan hukukunda da ortak velayet, hukuki velayet (legal custody) ve fiziksel velayet (physical custody) ayrımına götürmüștür (Caulley (n 13) 420). Ancak bu sistemde de yaşanan kavramsal değişiklikler sonucu hukuki velayet kavramının karar verme otoritesi (decision-making authority), fiziksel velayetin ise ebeveynlik zamanı (parenting time) ifadeleri ile değiştirilmekte olduğu belirtilmektedir (ibid 421).

79 Türkçe terminolojide Obhut/garde ifadelerinin karşıllğı olarak "çocuğun himayesi” kavramının (örneğin bkz Erlüle (n 25) 235) yerine "alıkoyma” kavramının da kullanıldığı görülmektedir (örneğin bkz Tuba Birinci Uzun, 'Türk Medeni Kanunu'na Göre Velayetin Kullanılması ve Çocuğun Yüksek (Üstün) Yararı İlkesi Doğrultusunda Boşanmada ve Evlilik Dışı İlişkide Birlikte Velayet Modeli’ (2016) 6 Hacettepe Üniversitesi Hukuk Fakültesi Dergisi 135, 148)

80 Kurt (n 77) 159.

81 Bu modeller hakkında bkz Erlüle (n 25) 183-185.

82 PACE, 'Equality and Shared Parental Responsibility: The Role of Fathers' (2015) Resolution No 1468, bkz yuk n 8.
} 
noktalarından biri olan eşitlik kavramı açısından eleştirilere tabi tutulmuştur. Bazı yazarlara göre, sadece hukuki yetkiler anlamında sonuç doğuracak biçimde ortak velayet talebi, esasında sorumlulukta paralel bir artış olmadan hak ve kontrol yetkisi talebi anlamına gelmektedir. Babanın çocuğun gündelik yaşamına katılmadan velayetin icrasına dâhil olması, çocuğun bakımına ilişkin hak ve yükümlülüklerin eşit biçimde dağıtılmasını sağlamamaktadır, çünkü fiziksel bakıma ilişkin sorumluluk olmaksızın karar alma gücü sağlamaktadır ${ }^{83}$. Karar alma yetkisi ile birlikte çocuğun himayesine ilişkin yetkilerin de dönüşümlü olarak kullanılması ise, çocuğun bakımına ilişkin sorumluluğun daha dengeli biçimde paylaştırılmasını sağlayarak boşanma sonrasında daha eşitlikçi bir görüntü çizmektedir. Ancak eğer çocuğun bakımı ortak yaşam sırasında birlikte gerçekleştirilmediyse, babanın kimliği çalışma hayatı üzerinden, annenin kimliği ise münhasıran annelik üzerinden kurulduysa, sonradan getirilen bu eşitliğin anne ve baba arasındaki eşitliğe gerçekten hizmet edip etmediği tartışılması gereken bir husus olmaktadır. Ayrıca bu sistem çocuğun yararı açısından da eleştirilmektedir. Bu noktada en çok değinilen husus, çocuğun bir evden diğerine gittiği durumlarda, sabit yerleşim yerinin olmamasının ve sürekli taşınma durumunun çocuğun gelişimi üzerinde yaratabileceği sakıncalardır ${ }^{84}$. Bu sakıncaların azaltılması için ebeveynlerin iş birliği içinde davranmaya gönüllü olmaları, her birinin çocuğun maddi ve manevi ihtiyaçlarını bağımsız olarak giderebilmelerini ve evler arasında yakınlık kurabilmelerini sağlayan gelir düzeyine sahip olmaları gerekir ${ }^{85}$. Keza şiddet eğilimlerinin de bu tür dönüşümlü bir modele karar verilmesinde birincil önemde görülmesi gerekir; aksi takdirde çocuğun himayesi yetkisinin paylaşılmakta olması şiddet eğiliminde olan tarafın bu eğilimini sürdürmesi için zemin sağlayacaktır ${ }^{86}$.

Yukarıda işaret edilen veriler çerçevesinde ister sadece önemli yetkilerde paylaşıma dayansın, isterse bunun yanında çocuğun himayesinde de paylaşım sağlasın, ortak velayet sisteminin de çocuğun yararını ayrımcılıktan uzak biçimde gerçekleştirmeye her zaman muktedir olmadığ 1 anlaşılmaktadır. Bununla beraber çeşitli ülkelerde geliştirilen ortak velayet sistemleri bazı ortak noktalar barındırmalarına rağmen farklı noktalar da içermektedirler. Bu çerçevede Kıta Avrupası'nda benimsenen sistemlerden bazıları ${ }^{87}$ ile bunlardan farklılaşan Amerikan Hukuk Enstitüsü'nün geliştirdiği ortak velayet modelinin ana hatları aşağıda açıklanacaktır.

\footnotetext{
3 Anne Marie Delorey, 'Joint Legal Custody: A Reversion to Patriarchal Power' (1989) 3 (33) Canadian J Women \&Law 33, 38-39'dan aktaran Kay (n 17) 37.

84 Scott ve Emery (n 34) 70; Dekeuwer-Defossez (n 13) 352; Caulley (n 13$) 424$.

85 Benzer yönde, Caulley (n 13) 445.

86 ibid 446; Boyd (n 46) 166.

${ }^{87}$ Bu çalışmada yer verilmeyen hukuk sistemlerini de içeren karşılaştırmalı hukuk bilgileri için bkz Kudret Güven, 'Türk Hukukunda Evliliğin Sona Ermesi Halinde ve Evlilik Dışı İlişkide Velayet Hakkının Geldiği Son Nokta: Ortak Velayet' (2018) 4 (1) Başkent Üniversitesi Hukuk Fakültesi Dergisi 11, 13 vd.
} 


\section{Kıta Avrupası'nda Ortak Velayet Örnekleri}

\section{a. Fransiz Hukukunda Ortak Velayet}

Fransız hukukunda 11 Temmuz 1975 tarihli kanun (n 75-617) ile velayetin boşanan eşlerden hangisine bırakılacağının tayininde boşanmada kusurun etkisi tamamen ortadan kaldırılarak çocuğun yararı velayetin tayininde tek kıstas haline getirilmiş, bunun üzerine velayetin büyük ölçüde annelere verilmeye başladığ 1 gözlemlenmiştir ${ }^{88}$. Bu durum karşısında, 80'li yıllardan itibaren, çocuklarının hayatlarından çıkarılmış olduklarını iddia eden babalar tarafından ortak velayete yönelik talepler yoğunlaşmaya başlamışıır ${ }^{89}$. Bu taleplerin ve eşitlik söylemlerinin etkisiyle ortak velayet kurumu peyderpey hukuk düzenine girmeye başlamıştır; Fransa bu kurumu ilk aşamada tarafların anlaşmasına dayalı olarak, daha sonra anlaşma olmadan da uygulanacak bir kural olarak kabul etmiştir ${ }^{90}$.

Hâlihazırda yürürlükte olan Fransız Medeni Kanunu (Code Civil/CCiv) hükümlerine göre, çocuğun yararını sağlamaya yönelmiş haklar ve görevler bütününü ifade eden velayet (CCiv m 371-1/I), anne ve baba tarafindan birlikte kullanılır (CCiv m 372/I) ve anne babanın ayrılması bu durum üzerinde etki doğurmaz (CCiv m 373-2/I). Böylelikle ortak velayetin çocuğun menfaatine en uygun çözüm olduğu düşüncesi kanun koyucu tarafından benimsenmiş olmaktadır ${ }^{91}$. Hâkim, ancak çocuğun yararı (l'intérêt de l'enfant) bunu gerektiriyorsa velayeti anne ile babadan sadece birine verebilir (CCiv m 373-2-1/I). Kanun koyucu, aşağıda göreceğimiz İsviçre ve Alman sistemlerinden farklı olarak, ortak velayet çerçevesinde ortak karar alma gereğine sınırlama getirmemiştir; çocukla ilgili karar alınması gereken her durumda ebeveynlerin birlikte hareket etmesi gerekir. Ancak kanun koyucu iyi niyetli üçüncü kişilerin her bir ebeveynin velayete ilişkin olağan işlemleri diğerinin rızasıyla yaptığını varsayabileceği yönünde bir kural getirmiş̧tir (CCiv m 372-2). Bu durumda çocukla birlikte yaşayan kişiye tek başına karar alma yönünde fiilî bir üstünlük tanınmış olmaktadır ${ }^{92}$.

Kanun koyucu, çocuğun gündelik yaşamının düzenlenmesi ve fiili bakımı meselesini, çocuğun yerleşim yerine (résidence) ilişkin özel bir düzenlemeyle velayetten ayırmıştır. Hâkim, çocuğun ikametini dönüşümlü olarak belirleyebilir veya çocuğun münhasıran ebeveynlerden biri ile ikamet edeceğini kararlaştırabilir (CCiv m 373-2-9/I); bu durumda diğer ebeveynin ziyaret hakkı düzenlenecektir

\footnotetext{
Dekeuwer-Defossez (n 13) 351.

89 ibid.

90 ibid 362; Dionisi-Peyrusse ve Pichard (n 16) 489.

$91 \mathrm{Bu}$ değişiklikten önce ortak velayet talepleri çocuğun yararı gerekçesiyle reddedilirken yapılan kanuni değişikliğin gerekçesinin de yine çocuğun yararı olduğu, taban tabana zıt sonuçların tamamının çocuğun yararı gerekçesine dayandırıldığı yönünde, bkz Dekeuwer-Defossez (n 13) 352.

92 Dionisi-Peyrusse ve Pichard (n 16) 491.
} 
(CCiv m 373-2-9/III). Bu yönde karar alırken hâkimin dikkate alacağı etmenler ise 373-2-10 ve 373-2-12 maddeleri arasında sıralanmıştır. Anne ve baba da velayetin icrasına ilişkin hususları, bu arada çocuğun kimin yanında kalacağını, hâkimin onayına tabi bir anlaşma ile belirleyebilirler; hâkim iradelerin serbest olmadığını veya yapılan anlaşmanın çocuğun yararına uygun olmadığını tespit ederse anlaşmayı onaylamayacaktır (CCiv m 373-2-7).

Böylece Fransız hukukunda boşanmanın velayet üzerinde etki doğurmayacağı ve ortak velayetin, hâkim çocuğun yararının aksini gerektirdiğini tespit etmediği sürece uygulanacak bir kural olarak benimsenmiş olduğu görülmektedir. Çocuğun kimin yanında kalacağı meselesinde ise kanun koyucu genel bir kural koymamış, hâkime sorunu somut olaya göre, dönüşümlü ikamete de karar verebilecek şekilde çözme görevi verilmiştir. Fransız hukukunda benimsenen ortak velayet modelinin en çok eleştirilen kısmı da çocuğun himayesi boyutuna, yani dönüşümlü ikamet çözümüne ilişkindir. Bazı yazarlar dönüşümlü ikametin çocukları sabit bir yaşam örüntüsünden mahrum bıraktığını ileri sürmüştür ${ }^{93}$. Bir diğer görüşe göre, kanunda belirtilen ölçütler (CCiv m 373-2-10 - 373-2-12) çocuğun yerleşim yerinin annenin yerleşim yeri olarak belirlenmesine yönlendirmekte, bu durum cinsiyet rollerine ilişkin yerleşik yapıyı güçlendirmekte, eşitlikçi bir yapı ise dönüşümlü ikamet senaryolarının sıklaşmasını gerektirmektedir ${ }^{94}$. Başka bir görüşe göre ise dönüşümlü ikamet, ancak üstlendikleri roller açısından birbirlerine yakın, mesleki aktivite açısından görece eşit konumdaki ebeveynler için sağlıklı bir çözüm teşkil edebileceğinden, dönüşümlü ikametin bu unsurlardan bağımsız olarak benimsenmesi eşler arasında eşitlik yaratmaya muktedir bir adım teşkil edememektedir ${ }^{95}$.

\section{b. İsviçre Hukukunda Ortak Velayet}

İsviçre hukukunda 1 Ocak 2000'de yürürlüğe giren boşanma hukuku revizyonu sonrasında önceden kategorik olarak reddedilen ${ }^{96}$ ortak velayet mümkün hale getirilmiş, ancak ebeveynlerin ortak talepte bulunmaları ve çocuğun bakımına ve masraflarına katılımla ilgili anlaşma yapmış olmaları aranmış, hâkime de bu anlaşmanın çocuğun yararına uygun olduğunu denetleme görevi verilmiştiir ${ }^{97}$. Bu şartlar çerçevesinde ortak velayete ilişkin anlaşmalar kapsamında çocuğun dönüşümlü

93 Dekeuwer-Defossez (n 13) 352.

94 Dionisi-Peyrusse ve Pichard (n 16) 499-500. Yazarlara göre, çocuğa ilişkin kararların birlikte alınması gerekmesine rağmen, iyiniyetli üçüncü kişiler karşısında her bir ebeveynin diğerinin rızasıyla işlem yaptığı yönündeki yasal karine (CCiv m 372-2) nedeniyle, genellikle çocukla yaşayan kişi olan anneye üstünlük tanınmış olmakta ve böylece babaların menfaatlerini feda edilmektedir (491).

95 Michelle Cottier, Eric Widmer, Myriam Girardin, Sandrine Tornare, 'La garde alternée' (2018) Die Praxis des Familienrechts $297,305$.

96 Bkz yuk n 71.

97 Guillaume Choffat, 'Réflexions sur la réforme de l'autorité parentale conjointe: une promesse déçue?'(2015) 2 La semaine judiciaire 167, 168; Heinz Hausheer, Thomas Geiser ve Regina Aebi-Müller, Das Familienrecht des Schweizerischen Zivilgesetzbuches, (6. Bas1, Stämpfli Verlag 2018) 198; Erlüle (n 25) 211. Mahkemelerin çocuğun üstün yararını belirlerken kullandıkları bazı ölçütler için bkz Hausheer, Geiser ve Aebi-Müller (n 97) 197. 
olarak himaye edilmesine ilişkin anlaşmalar da mahkemelerin onayından geçmiştir ${ }^{98}$. 1 Temmuz 2014'te yürürlüğe giren değişiklikler sonucu ise boşanmanın velayet üzerindeki etkisi ortadan kalkmış ve boşanma halinde velayetin birlikte kullanılması kural haline getirilmiştir ${ }^{99}$.

İsviçre Medeni Kanunu'nun (Schweizerisches Zivilgesetzbuch/ZGB) 298. maddesine göre hâkim, boşanma halinde ancak çocuğun yararı (Kindeswohl/bien de l'enfant) bunu gerektiriyorsa velayeti eşlerden birine verebilecektir. Başka bir deyişle, boşanma evlilik esnasında ortak biçimde kullanılan velayet üzerinde etki doğuran bir olgu olmaktan çıkmıştır ${ }^{100}$. Ancak bu noktada ebeveynlerin anlaşması tek başına anlam ifade etmemekte ve mahkemenin her halükarda velayetin ne şekilde kullanılacağına karar vermesi gerekmektedir ${ }^{101}$. Sistemdeki yenilik, ortak velayetin anlaşmaya dayalı bir istisna olmaktan çıkıp kural haline getirilmiş olmasındadır. Paradigma tamamen tersine dönmüş, tek başına velayet, çocuğun bu yöndeki yararı ile gerekçelendirilmesi gereken, istisnai bir çözüme dönüşmüştür ${ }^{102}$. Böylece tıpk1 Fransız hukukunda olduğu gibi, İsviçre hukukunda da ortak velayetin çocuğun yararına en uygun çözüm olduğu kanun marifetiyle benimsenmiş olmaktadır ${ }^{103}$. Kanunda tek başına velayetin ne zaman çocuğun yararına uygun çözüm olarak kabul edileceğine ilişkin gösterge bulunmamaktadır. Öğretide ve uygulamada tek başına velayete karar verilebilmesi için velayetin kaldırılması şartlarının bulunmasının gerekmediği görüşü benimsenmektedir ${ }^{104}$. Federal Mahkeme, anne ve baba arasında önemli ve süreklilik arz eden iletişim problemlerinin varlığı halinde, eğer bu durum çocuğun yararı açısından olumsuz sonuç doğuruyorsa ve tek başına velayetin durumu düzeltebileceği anlaşılabiliyorsa tek başına velayete hükmedilebileceğini belirtmiştir. Ancak mahkeme bunun her ailede özellikle boşanma sonrasında meydana gelebilecek anlaşmazlıklar halinde söz konusu olmayacağının, tek başına velayetin istisna olarak kalması gerektiğinin de altını çizmiştir ${ }^{105}$. Öte yandan kanunda tarafların velayete ilişkin ortak taleplerinin ve mümkün olduğunca çocuğun fikrinin dikkate alınması gerektiği de öngörülmüştür (ZGB m 133/II).

\footnotetext{
98 Choffat (n 97) 175.

99 Erlüle (n 25) 217; Olivier Guillod ve Sabrina Burgat, Droit de la famille, (4. Bas1, Collection Neuchateloise Helbing Lichtenhahn 2016) 148

100 Büchler ve Vetterli (n 18) 241.

101 ibid; Erlüle (n 25) 217-218; Andrea Büchler ve Sandro Clausen, 'Art. 298' iç Ingeborg Schwenzer ve Roland Fankhauser (edr), FamKommentar Scheidung Band I: ZGB (3. Bas1, Stämpfli Verlag AG 2017) 436-437.

102 Choffat (n 97) 178; Büchler ve Vetterli (n 18) 242; Erlüle (n 25) 218.

103 Hausheer, Geiser ve Aebi-Müller (n 97) 198; Büchler ve Clausen (n 101) 406; Choffat (n 97) 176; Cottier, Widmer, Girardin, Tornare (n 95) 314.

104 Hausheer, Geiser ve Aebi-Müller (n 97) 411; Büchler ve Vetterli (n 18) 241; Cottier, Widmer, Girardin, Tornare (n 95) 315 16; Büchler ve Clausen (n 101) 419-420; Bu yönde bir karar için, bkz BGE 141 III 472, <https://www.bger.ch/index.htm> Erişim Tarihi 11.05.2020.

105 BGer 5A-923/2014, 27.08.2015, <https://www.bger.ch/index.htm> Erișim Tarihi 11.05.2020. Aynı görüşte, bkz Büchler ve Vetterli (n 18) 242. Tek başına velayet kararını haklı gösterebilecek durumlara örnekler için bkz Hausheer, Geiser ve AebiMüller (n 97) 412.
} 
Ortak velayet kural olarak çocukla ilgili tüm kararların birlikte alınmasını gerektirmektedir, ancak çocuğa fiilen bakan ebeveyne günlük veya ivedi kararlar açısından ve diğer ebeveyne makul bir çaba ile ulaşmanın mümkün olmaması hallerinde tek başına karar alma yetkisi tanınmıştır (ZGB m 301). Böylece fiilen çocukla birlikte yaşamayan ebeveynin, karar alma ayrıcalığını diğer ebeveynin hareket alanını kısıtlamak için kullanmasına engel olunmaya çalışılmıştır ${ }^{106}$. Belirli bir konunun günlük hayata ilişkin karar alma yetkisinin kapsamına girip girmediği, amaca uygun bir yorumla, kararın etkilerine göre ve çocuğun hayatının gidişatına ilişkin temel nitelikteki noktalara temas edip etmemesine göre değerlendirilecektir ${ }^{107}$. Federal Mahkeme ise birlikte karar alınması gereken halleri çocuğun hayatını şekillendirici yol ayrımları ile sınırlı tutmuş ve böylece günlük hayata ilişkin kararların çerçevesini oldukça geniş biçimde çizmiştir ${ }^{108}$.

Ortak velayetin genel kural olarak benimsenmiş olması ile çocuğun yaşamını fiilen kimin yanında devam ettireceği meselesinin velayetten ayrılması gerekmiş ve çocuğun himayesi kavramı (Obhut/garde) da değişikliğe uğramıştır ${ }^{109}$. Çocuğun yerleşim yerini belirleme yetkisi çocuğun himayesinden ayrılarak velayetin birlikte icrası kapsamına giren bir yetki haline gelmiş, çocuğun himayesi, çocuğun belirli bir ev yaşantısı çevresinde fỉilî bakımının gerçekleştirilmesine ilişkin işlevlere indirgenmiştir ${ }^{110}$. Kanun koyucu çocuğun himayesinin nasıl icra edileceği konusunda genel kural koymamış, bunu belirleme yetkisini hâkime bırakmış, 1 Ocak 2017'de yürürlüğe giren çocuk nafakası revizyonu sonrasında hâkimin başvurabileceği çözüm yollarına dönüşümlü himaye de eklenmiştir (ZGB m 298/II $)^{111}$. Bu konuda ortak velayette olduğu gibi genel bir kural söz konusu olmayıp, durumun gereklerine göre, çocuğun menfaatleri açısından uygun olan çözümün tespit edilmesi söz konusudur ${ }^{112}$. Ebeveynlerin anlaşmas $1^{113}$ ve çocuğun rızası hâkimi bağlayıcı değildir ${ }^{114}$. Hâkim, münhasıran çocuğun yararı ölçütüne dayalı olarak ve gerekçesini soyut varsayımlara değil, somut olaydaki verilere

\footnotetext{
106 Guillod ve Burgat (n 99) 150.

107 Büchler ve Vetterli (n 18) 248.

108 BGer 5A_609/2016, 13.02.2017, <https://www.bger.ch/index.htm> Erişim Tarihi 11.05.2020.

109 Cottier, Widmer, Girardin, Tornare (n 95) 298. Kavramın eski sistemdeki anlamı ve revizyon sonrası anlamı için bkz Erlüle (n 25) 235-236.

110 Büchler ve Vetterli (n 18) 246; Hausheer, Geiser ve Aebi-Müller (n 97) 415; Büchler ve Clausen (n 101) 406.

111 Federal Mahkeme, bu düzenlemeden önce de mahkemenin dönüşümlü himayenin çocuğun yararına en uygun çözüm olup olmadığını değerlendirmesi gerektiğini ve bunun tarafların anlaşmasını da gerektirmediğini ifade etmiştir (BGE 142 III 612, BGer 5A_425/2016, <https://www.bger.ch/index.htm> Erişim Tarihi 11.05.2020).

112 Hausheer, Geiser ve Aebi-Müller (n 97) 419. Ortak velayetten günlük bakımın da ortaklaşa gerçekleştirileceğine dair bir kural çıkarılamayacağı yönünde, Büchler ve Clausen (n 101) 407. Ancak yazarlar, kanun değișikliğinin amaçlarından birinin çocuk bakımına giderek daha fazla katılmakta olan babaların hukuki konumunu iyileştirmek olduğunu, bu nedenle babaların günlük hayattaki varlığının güçlendirilmesi gerektiğini belirtmektedirler; Büchler ve Clausen (n 101) 407.

113 Büchler ve Vetterli (n 18) 246; Cottier, Widmer, Girardin, Tornare (n 95) 298; Büchler ve Clausen (n 101) 414.

114 Büchler ve Clausen (n 101) 414.
} 
dayandırarak karar vermek durumundadır ${ }^{115}$. Çocuğun bakımına fiilen katılma konusunda görece eşit rol dağılımının nasıl sağlanacağı duruma göre değişebilir; ancak dönüşümlü himayedenbahsedilebilmesi için ebeveynlerin velayeti birlikte kullandıkları ve çocukla aşağı yukarı eşit zaman aralıklarıyla dönüşümlü olarak ilgilendikleri bir yapının kurulması gerekir ${ }^{116}$.

Her ne kadar kanun koyucu tarafından diğer seçenekler kadar olası bir çözüm gibi düzenlenmiş olsa da, İsviçre öğretisinde dönüşümlü himaye modelinin çocuğun yararına uygun bir çözüm olarak karşımıza çıkmasının çok sınırlı sayıda olayda söz konusu olabileceği belirtilmektedir. Öncelikle çocuğun her bir ebeveynden her ayrılışında yaşayacağı duygusal kayıp ve güvensizlik duygusunu aşabilmesi için belirli bir duygusal ve bilişsel olgunluğa sahip olmasının aranması gerekir ${ }^{117}$. Keza eğer dönüşümlü himaye çocuğun hayatında istikrarın sağlanması amacına hizmet ediyorsa, geçmiş ilişki yapısının da dikkate alınması gerekecektir, nitekim dönüşümlü himayenin istikrar beklentisine ancak ebeveynler evlilik sırasında da çocuğa birlikte bakmışlarsa cevap vereceğine dikkat edilmesi lazımdır ${ }^{118}$. Ebeveynler arasındaki iş birliği düzeyi ve aralarındaki uyuşmazlıkları çözme biçimleri de dikkate alınması gereken temel etmenlerdendir ${ }^{119}$. Öte yandan çocuğun sürekli biçimde yaşayacağı fiziksel değişikliklerin günlük hayatında yol açacağı istikrarsızlığın etkilerinin azaltılması için ciddi bir organizasyon gereklidir. Bu organizasyon anne ve babanın hem çocuğa zaman ayırabilme ve eğitim verebilme, hem de çocuğun maddi ihtiyaçlarını karşılayabilme açısından görece birbirine eşit imkânlara sahip olmalarını gerektirir. Eşyaların, kıyafetlerin ikişer tane olması, evlerin birbirine yakın olması, her iki ebeveynin çocukla ilgilenebilecek şekilde esnek çalışma şartlarına sahip olması gibi önlemlerle çocuğun ilişkilerinde ve okul hayatında belirli bir devamlılık içinde olması sağlanabilir ${ }^{120}$. Ancak bunun için gerekli maddi olanakların anne babanın değiştirmelerinin güç olduğu maddi ve yapısal koşullara bağlı olduğu da unutulmamalıdır. Örneğin anne ve babanın yaptıkları işlerin yakın düzeyde gelir getiriyor olup olmaması, çocukların bakımını sağlayabilecek aile dışı yapıların ulaşılabilirliği, sosyal yardımın erişilebilir olup olmaması gibi etmenler dönüşümlü himayenin başarısını koşullandıran etmenler olarak karşımıza çıkmaktadır ${ }^{121}$. $\mathrm{Bu}$ şartlar açısından birbirine yakın olan anne ve babalar ise çoğunlukla evlilik ilişkisi içinde de çocuğun bakımını ortaklaşa gerçekleştiren, yüksek gelir ve eğitim seviyesine sahip anne babalar olmaktadır. Böylece dönüşümlü velayetin ancak sosyal

\footnotetext{
115 Dönüşümlü himayenin çocuğun yararına uygun olup olmadığı değerlendirilirken somut olayın şartlarına bakılacağı, belirli bir himaye modelinin lehinde veya aleyhinde sonuçlara varan psikolojik veya psikiyatrik çalışmalardan çıkarımda bulunulamayacağı yönünde bkz BGE 142 III 612, <https://www.bger.ch/index.htm> Erişim Tarihi 11.05.2020.

116 Cottier, Widmer, Girardin, Tornare (n 95) 301.

117 ibid 311

118 Büchler ve Clausen (n 101) 409.

119 ibid 413; Büchler ve Vetterli (n 18) 246.

${ }_{120}$ Cottier, Widmer, Girardin, Tornare (n 95) 312.

121 ibid 311-312.
} 
açıdan avantajlı çevrelerde, belirli bir aile içi iş bölümü biçiminin devamı olarak başarı sağlayan bir model olarak kabul görebileceği ortaya çıkmaktadır ${ }^{122}$.

\section{c. Alman Hukukunda Ortak Velayet}

Alman Medeni Kanunu'nda (Bürgerliches Gesetzbuch/BGB) da boşanmanın ebeveynlerin o zamana kadar birlikte icra ettikleri velayet üzerinde etkisinin olmayacağ1, böylece ortak velayetin kural olarak boşanmadan sonra da devam edeceği öngörülmüştür (BGB $§ 1671)^{123}$. Tek başına velayet kararı verilebilmesi için ebeveynlerden birinin mahkemeden bu yönde talepte bulunması gerekir. Eğer diğer ebeveyn de buna razı ise ve on dört yaşını tamamlamış olan çocuk bu anlaşmaya itiraz etmezse eşlerden biri velayeti tek başına icra edecektir. Bu şartların yerine gelmesi durumunda mahkeme ebeveynlerin tek başına velayet üzerinde anlaşmalarının çocuğun yararına uygun olup olmadığını kontrol edemeyecektir ${ }^{124}$. $\mathrm{Bu}$ durumda hâkimin anlaşmaya müdahalesi ve çocuğun yararına uygunluk açısından değerlendirme yapabilmesi, çocuğun fiziksel, zihinsel veya psikolojik yararlarının veya malvarlığının tehlikeye girmesi halinde hâkimin müdahalesini düzenleyen BGB $\S 1666$ 'nın uygulama alanına giren bir halin bulunmasına bağlıdır ${ }^{125}$. Ebeveynlerin tek başına velayet üzerinde anlaşamamaları veya on dört yaşını doldurmuş çocuğun anlaşmaya itiraz etmesi halinde mahkeme tek başına velayete karar verilmesi yönündeki talebi çocuğun yararına göre değerlendirecek ve çocuğun yararı açısından en uygun çözüm olduğuna kanaat getirirse tek başına velayet yönünde karar verebilecektir (BGB $\S 1671 / \mathrm{I}$ ). Bu sistemde ortak velayet ile tek başına velayet arasında bir kural-istisna ilişkisi olmadığı, nitekim şüphe halinde çocuğun menfaatine en uygun olan çözümün ortak velayet olarak benimsendiğini gösteren kanuni bir emare olmadığı kabul edilmektedir ${ }^{126}$. Bununla beraber, boşanmanın velayet üzerinde karar almayı kanun gereği zorunlu kılacak bir olgu olmaktan çıkarılmış olması ve taraf

122 ibid 322. İsviçre'de erkekler ile kadınlar arasında, iş hayatında farklı yönelimler izlemeleri nedeniyle gelir eşitsizliği bulunduğu, çocuklu her iki çiftten birinde erkeğin tam zamanlı, kadının yarı zamanlı çalıştı̆̆ının görüldüğü, özellikle üst gelir düzeyinden olmayan çevrelerde, iș piyasasındaki eşitsiz yapı nedeniyle dönüșümlü velayetin gerektirdiği eșit maddi olanaklara sahip olma şartının sağlanmasının çok zor olduğu yönünde, ibid 324. Yazarlar ayrıca bu çevrelere mensup kadınların, tam zamanlı iş sahibi olsalar bile nafaka olmaksızın kendilerinin ve çocuklarının ihtiyaçlarını gideremediklerini belirtmektedirler, ibid 324 .

123 Bu konuda Alman hukukunun gelişimi için, bkz Kostka (n 73) 89-91.

124 Harald Vogel, 'Ausgewählte Probleme aus dem Recht der elterlichen Sorge bei getrennt lebenden Eltern' (2005) Familie Partnerschaft Recht 65, 69; Christiane Lang, 'Elterliche Sorge' iç Klaus Shnitzler (ed), Münchener Anwaltshandbuch Familienrecht (5. Bası, C H Beck 2020) para 191. Ebeveynlerin anlaşması halinde tek başına velayeti tamamen ebeveynlerin takdirine bırakan ve gerekçelendirme yükümü getirmeyen bu düzenleme eleştirilmektedir; bkz Eva Schumann, 'Gutachten, B 32 f. (= These 1); weitere Reformideen bei Hammer', FamRZ 2018, 229 (231 ff)'dan aktaran Marina Wellenhofer, 'Gemeinsam getragene Elternverantwortung nach Trennung und Scheidung' (2018) Neue Juristische Wochenschrift 2758, 2759.

125 Vogel (n 124) 69; Lang (n 124) para 191.

126 Vogel (n 124) 69; Jürgen Schmid, 'BGB § 1687' iç Werner Schulz ve Jörn Hauß (edr), Familienrecht, Handkommentar, (3. Bas1, Nomos 2018) para 2; Dagmar Kaiser, 'Elternwille und Kindeswohl - für das gemeinsame Sorgerecht geschiedener Eltern' (2003) Familie Partnerschaft Recht 573; Hennemann (n 77) para 13; Lang (n 124) para 203, ancak yazar, evli olmayan kişilerin ortak velayet sahibi olmalarına ilişkin düzenlemeden bu yana en azından ortak velayetin çocuğun yararına aykırı olmadığına ilişkin bir kanuni varsayım bulunduğunu ifade etmektedir. Bu gelişmeler ışı̆̆ında yazara göre artık ortak velayetin kural olarak anlaşılması gerekir. 
anlaşmalarının mahkeme önüne gidilmesini engelleyici etkisi, o ana kadar geçerli olan ortak velayetin de fiilen devamını sağlamaktadır ${ }^{127}$. Başka bir deyişle ortak velayetin kural olarak kabulü, mahkemenin velayete ilişkin karar almasını gerektiren alanın daraltılmasıyla gerçekleştirilmiş olmaktadır.

Yargı kararlarında tek başına velayete karar verilmesini haklı gösteren sebeplerden biri olarak ebeveynlerden birinin çocuğu yetiştirme kabiliyetine sahip olmaması ölçütü önemli yere sahiptir (Erziehungsfähigkeit). Bu çerçevede alkol problemi, diğer eşe şiddet uygulanması, cinsel istismar, çocuğun diğer ebeveynle iletişimine engel olunması bir ebeveynin çocuğu yetiştirme kabiliyetine sahip olmadığını gösteren emareler olarak görülmüştür. Ayrıca, çocuğu ilgilendiren konularda sürekli fikir ayrılığına düşülmesi, ebeveynlerin iletişim kuramamaları ve iş birliğine yanaşmamaları, çocuğun iki ebeveyn arasında kalması gibi unsurlar da ortak velayetin çocuğun yararına uygun olmadığ1 sonucuna götürmektedir ${ }^{128}$.

Velayetin boşanmadan sonra birlikte icra edilmesi halinde görev ve yetki paylaşımın nasıl yapılacağı konusunda kanun ebeveynlerin ayrı yaşamasını dikkate alacak biçimde düzenleme yapmıştır. Buna göre ebeveynlerin ancak çocuk için önemli nitelikteki kararları birlikte almaları gerekmektedir; çocuğun yerleşim yerinin, okulunun ve eğitim biçiminin, dini eğitiminin seçilmesi, önemli risk taşıyan tıbbi müdahalelere karar verilmesi gibi konular örnekler arasında gösterilmektedir ${ }^{129}$. Çocuğun ebeveynlerin anlaşması veya mahkeme kararı sonucu yanında yaşadığı ebeveyn, gündelik hayata ilişkin konularda tek başına karar alma yetkisine sahiptir. $\mathrm{Bu}$ konular, sıklıkla karşılaşılabilen ve çocuğun gelişiminde geriye döndürülmesi güç etkiler doğurmayacak nitelikteki konular olarak tanımlanmıştır (BGB §1687). Keza kanunda çocukla yaşamakta olan ebeveynin, çocuğun fiilî bakımına ilişkin konularda da tek başına karar alabileceği belirtilmiştir (BGB $§ 1687$ ). Bu ebeveyne tek başına karar alma yetkisi tanınması ile bir yandan çocukla birlikte yaşamayan ebeveynin çocukla ilgili meselelere sürekli olarak müdahil olmasına ve böylece yeni uzlaşmazlık alanlarının yaratılmasına engel olunmas $1^{130}$, öte yandan bir ebeveyn ile çocuk arasındaki coğrafi uzaklığın ortak velayete engel olacağı yönündeki endişelerin bertaraf edilmesi amaçlanmıştır ${ }^{131}$.

Boşanma sonrası çocuğun bakım sorumluluğunun nasıl paylaştırılacağı ise bu hükümlerde düzenlenmemiştir, ancak kanun koyucunun ebeveynler arasındaki

\footnotetext{
127 Vogel (n 124) 69.

128 ibid 65-66; ayrıntılı bilgi için bkz Hennemann (n 77) para 95-139; Schmid (n 126) para 8 vd. Orantıll1lk ilkesi çerçevesinde, taraflar arasındaki sorunlar tek başına velayeti gerektirmediği sürece tek başına velayet yerine ortak velayet çerçevesinde çocuğun taraflardan sadece biri ile yaşaması yönünde karar verilmesi gerektiği yönünde, bkz Vogel (n 124) 69.

129 Kaiser (n 126) 575; Dagmar Kaiser, 'Gemeinsame elterliche Sorge und Wechselmodell' (2008) Familie Partnerschaft Recht 143; ayrıntılı örneklendirme için bkz Heike Hennemann, 'BGB § 1687' iç Dieter Schwab, Münchener Kommentar zum $B G B$, Band 10 (8. Bas1, C H Beck 2020), para 13 vd; Lang (n 124) para 173.

130 Hennemann (n 129) para 1.

131 Vogel (n 124) 67; benzer yönde Kaiser (n 126) 576.
} 
yetki paylaşımını düzenlerken esas aldığı modelin "Rezidenzmodell" olarak bilinen, çocuğun belirli bir ebeveynin yanında sürekli olarak yaşadığı ve diğeri ile ziyaret hakk1 çerçevesinde görüştüğü model olduğu anlaşılmaktadır ${ }^{132}$. Kanun koyucu çocuğun nerede yaşayacağına ve bakımının nasıl gerçekleştirileceğine ilişkin boşanmaya özel bir karar alma tekniği belirlememiştir. Ancak ebeveynlerin anlaşmasının bu konuda da öncelikli olarak geçerli olacağı konusunda şüphe yoktur, nitekim çocuğun korunması hükümlerine istinaden müdahaleyi haklı kılan bir durum olmadıkça ortak velayetin nasıl icra edileceği konusunda ebeveynlerin ortak kararına riayet edilmesi velayet hukukunun genel kuralıdır. Bu çerçevede ebeveynler, çocuğun ağırlıklı olarak belirli bir ebeveynle yaşaması (Rezidenzmodell), çocuğun aynı evde yaşaması ama ebeveynlerin dönüşümlü olarak bu evde kalması (Nestmodell) ve çocuğun birbirine yakın zaman aralıklarıyla her bir ebeveynin evinde dönüşümlü olarak yaşaması (Wechselmodell) seçeneklerinden birini seçebilirler ${ }^{133}$. Kanunun açık düzenleme yapmamış olması karşısında, tarafların anlaşamaması halinde hâkimin dönüşümlü himaye yönünde bir bakım modeline karar verip veremeyeceği ise tartışlan bir konudur ${ }^{134}$.

\section{Amerikan Hukuk Enstitüsü’nün Ortak Velayet Modeli}

Amerikan Hukuk Enstitüsü (American Law Institute), Amerika Birleşik Devletleri'nde hukuku uyumlulaştırma ve reform önerileri getirme konularında çalışmalar yapan bir kuruluştur. Enstitü, resmî aile ilişkisinin sona ermesinde uygulanması gereken kurallara ilişkin olarak kanun değişikliği önerilerini içeren ilkelerini (Principles of the Law of Family Dissolution) 2000 y1lında kabul etmiştir ${ }^{135}$. Ülkede birincil bakıcı kuralının ve Kıta Avrupası'ndakine benzer yapıdaki ortak velayet kuralının ${ }^{136}$ yanında baskın şekilde uygulanan çocuğun üstün yararı ölçütünün açık uçlu niteliğinin yarattığı sakıncalar ${ }^{137}$, özellikle oluşan belirsizliğin çocuğun

132 Lang (n 124) para 167; benzer yönde Hennemann (n 129) para 4; Kaiser (n 129) 143. Kanun koyucunun çocukla yaşayan kişiye tek başına karar alma yetkisi tanımış olmasından tek başına himaye modelini esas aldığı ortaya çıkmaktadır (Lang (n 124) 167). Keza sosyal yardım ve vergi hukuku kurallarının da çocuğun tek bir ebeveynle yaşaması modeline göre yapılandırılmış olduğu belirtilmektedir (Wellenhofer (n 124) 2758).

133 Lang (n 124) para 167.

134 Bu konuda bkz Hennemann (n 77) para 30, Wellenhofer (n 124) 2760. Dönüşümlü himaye modelinin anlaşma ile kararlaştırılabileceği kabul edilmekle beraber (Hennemann (n 77) para 28), uygulamada yaygın bir model olmadığ (Argiris Balomatis, 'Das Wechselmodell in Europa' (2016) Neue Zeitschrift für Familienrecht 833 ) ve kural şeklinde yasalaştırılmasının da düşünülmediği (Wellenhofer (n 124) 2760) belirtilmektedir.

135 İlkeler bağlayıcı nitelik taşımayıp çağdaş aile hukuku anlayışı çerçevesinde iyi uygulama örnekleri sunmayı amaçlamaktadır (Marygold S Melli, 'The American Law Institute Principles of Family Dissolution, the Approximation Rule and SharedParenting' (2005) 25 (3) Northern Illinois University Law Review 347, 348). Bu ilkelerle güdülen amaçlar için genel olarak bkz James Herbie DiFonzo, 'Toward a Unified Field Theory of the Family: The American Law Institute's Principles of the Law of Family Dissolution' (2001) Brigham Young University Law Review 923, 924.

136 Amerika Birleşik Devletleri eyaletlerinde ortak velayet kuralının uygulanmasına örnekler bkz Caulley (n 13) 433434. Yazar, politik gelişmelerin ve kamuoyundaki söylemlerin ortak velayetin kural olarak kabulünün yaygınlaşarak gelişeceğini gösteren veriler içerdiğini belirtmektedir (434 vd). Amerika Birleşik Devletleri'de ortak velayetin kural olarak uygulanmasının eleştirisi için, bkz Caulley (n 13) 437 vd.

137 Robert F Kelly ve Shawn L Ward, 'Allocating Custodial Responsibilities at Divorce: Social Science Research and The American Law Institute's Approximation Rule' (2002) 40 (3) Family Court Review 350. 
yararına aykırı biçimde husumeti tırmandırmakta olması ${ }^{138}$ karşısında Enstitü, daha fazla öngörülebilirlik sağlama amacıyla yeni bir velayet modeli geliştirmiştir.

Söz konusu ilkeler de (ALI İlkeleri) Kıta Avrupası'nda yaygın olan eğilime paralel olarak ortak velayet modelini kural olarak benimsemekte ve hukuki karar alma yetkisi ile günlük bakım işlevleri arasında bir ayrıma gitmektedirler. İlkeler, eğer ebeveynlerin her ikisi de daha önceden makul şekilde ebeveynlik işlevleri icra etmişlerse ortak karar alma yönündeki bir uygulamanın devamının çocuğun yararına en uygun çözüm olacağ 1 fikrinden yola çıkmaktadır ${ }^{139}$. Çocuğun hayatına ilişkin konularda karar alma yetkisi, çocuğun yararı aksini gerektirmedikçe birlikte kullanılacak $^{140}$, bu durumun çocuğun yararına uygun olup olmadığ 1 belirlenirken geçmişte her bir ebeveynin çocukla ilgili kararlara katılım düzeyine ve ebeveynlerin bu konuda geçmişte gösterdikleri beceriye ve iş birliği düzeyine bakılacaktır ${ }^{141}$. Çocuğun bakımına ilişkin işlevler (care taking functions) ise, "çocukla iletişimi içeren veya başkalarının sağladığı iletişimi veya bakımı planlamayı ve denetlemeyi içeren işlevler" olarak tanımlanmıştır. Buna örnek olabilecek hallerin tüketici olmayan bir listesi verilmiş, bu listede çocuğun yemeğinden eğitimine, sağlık ihtiyaçlarından etik yönlendirmeye, gerekiyorsa bakıcı temin etmeye kadar uzanan geniş bir çerçeve çizilmiştir (ALI İlkeleri Bölüm 2.03) ${ }^{142}$. Çocuğun bakımına ilişkin bu işlevlerin kimin tarafından yerine getirileceğine ilişkin olarak ise iki aşamalı bir yaklaşım benimsenmiştir.

İlk aşamada konuyu anne ve babanın anlaşma ile çözmeleri için getirilen yasal teşvik mekanizmaları devreye sokulmaktadır. ALI İlkeleri, taraf anlaşmalarına ve uzlaşmacı çözüme büyük önem vermektedir. Buna göre, öncelikle tarafların ortaklaşa biçimde veya anlaşmıyorlarsa bireysel olarak hazırladıkları ebeveynlik planını mahkemeye sunmaları gerekmektedir ${ }^{143}$. Bu plan(lar)da tarafların çocukla geçmiş bakım ilişkilerini tanımlamaları ve gelecek için de bir bakım planı önerisi getirmeleri aranmaktadır ${ }^{144}$. Hâkimin ayrıca ebeveynlere bir eğitim programı takip etme yükümlülüğü yükleme veya arabuluculuk hizmeti almalarını önerme yönünde yetkisi vardır ${ }^{145}$. Tarafların bir plan üzerinde anlaşmaya varmaları halinde, hâkimin tarafların iradesinin sağlıklı olduğunu ${ }^{146}$ ve çocuğun yararının zedelenmediğini tespit ettiği ölçüde bu planı onaylaması gerekmektedir ${ }^{147}$. Hâkimin anlaşmayı reddetme

\footnotetext{
138 Melli (n 135) 352.

139 Caulley (n 13) 430.

140 Graham (n 39) 328; Melli (n 135) 349.

141 Caulley (n 13) 430 dn 210.

142 Kay (n 17) 43; Melli (n 135) 349 dn 5.

143 Graham (n 39) 323, Kelly ve Ward (n 137) 352.

144 Bartlett (n 14) 479; Melli (n 135) 350.

145 Bartlett (n 14) 479.

146 Kay (n 17) 41.

147 ibid; Bartlett (n 14) 479.
} 
gerekçelerinin sınırlandırılmış olması, ALI İlkeleri'nin, taraf anlaşmalarının hâkim tarafından onaylanmalarını çocuğun üstün yararına uygun olmalarına bağlayan geleneksel yaklaşımdan ayrıldığını göstermektedir ${ }^{148}$. Bu plan, sadece çocuğun himayesine ilişkin sorumlulukların paylaşılmasına ve bu konudaki gelecek anlaşmazlıkların nasıl çözüleceğine odaklanmakta ve ekonomik konularda anlaşma içermemektedir. Bu nedenle nafaka yükümlülüğünü azaltmak için velayet üzerinden pazarlık yapılmasını engelleyici bir yöntem olduğu da düşünülmektedir ${ }^{149}$.

Anne ve baba anlaşmaya varamazlarsa çocuğun himayesine ilişkin hak ve görevler ebeveynlerin çocukla daha önceki ilişkilerine göre paylaştırılacaktır (approximation rule) $)^{150}$. Bu kuralın özelliği, belirli bir aile ilişkisi içinde çocuğun bakımına iliş̧kin benimsenmiş olan iş bölümünün ayrılık sonrasına da devam etmesini sağlamasındadır ${ }^{151}$. Böylece çocuğun üstün yararının o aile içindeki geçmiş bakım örüntüsünün devamında olduğu kural biçiminde benimsenmiş olmaktadır. Bununla beraber bu genel kuralın uygulanmayacağı veya yumuşatılacağ haller de mevcuttur. Örneğin her bir ebeveyn için asgari bir görüşme zamanı ayrılmakta, kendini ifade edebilecek çocukların tutarlı ve makul tercihleri de göz önünde tutulmaktadır ${ }^{152}$. Bunun yanında (i) kendi refahları için gerekli görülüyorsa kardeşlerin bir arada tutulması, (ii) çocuğun ebeveynleriyle olan bağlarında veya ebeveynlerin çocuğun ihtiyaçlarını karşılama yetilerinde yüksek ölçüde oransızlık varsa çocuğun zarar görmesinin önlenmesi, (iii) uygulanması önemli derecede güçlük çıkaracak veya çocuğun istikrar ihtiyacına önemli derecede aykırı gelecek uygulamalardan kaçınılması ve (iv) çocuğa esaslı ve hemen hemen kesin bir zararın gelmesinin önlenmesi gibi amaçlarla da mahkeme geçmiş bakım örüntüsünden ayrılan bir plan benimseyebilir ${ }^{153}$. Keza ALI İlkeleri, eşlerden birinin çocuğa veya diğer eşe şiddet uygulama eğiliminde olduğu veya aşırı alkol veya uyuşturucu madde kullanımı içinde olduğu hallerde bu ebeveynin çocuğa erişimine sınırlar getirmektedir ${ }^{154}$.

Böylece görülmektedir ki ALI İlkeleri ile ortaya konulan çözüm, çocuğun hayatına etki edecek esaslı konularda karar alma yetkisini ebeveynlerin her ikisine de vermesi açısından Kıta Avrupası'nda benimsenen ortak velayet modeline yakın bir anlayışa dayanmaktadır. Ancak bu sonucun doğması için daha önceden de her bir ebeveynin makul ölçülerde bu karar alma sorumluluğunu yerine getirmiş olması aranmaktadır.

\footnotetext{
$\overline{148}$ Melli (n 135) 350-351.

149 Kay (n 17) 41.

150 Bartlett (n 14) 478; Scott ve Emery (n 34) 71; Graham (n 39) 326; Sutherland (n 33) 138; Kay (n 17) 42; Kelly ve Ward (n 137) 350; Caulley (n 13) 419.

151 Graham (n 39) 326. Bu yaklaşımın, Elizabeth S Scott'ın 1992'de yaptığı öneri esas alınarak geliştirildiği ve ebeveynlerin anlaşamamaları halinde benimsenecek yedek kural olarak önerildiği yönünde, Kay (n 17) 39. Elizabeth S Scott'ın konuyla ilgili çalışması için bkz Elizabeth S Scott, 'Pluralism, Paternal Preference, and Child Custody' (1992) 80 California Law Review 615.

152 Bartlett (n 14) 478-479.

153 ibid; Sutherland (n 33) 138; Melli (n 135) 355-356.

154 Bartlett (n 14) 478-479; benzer yönde Sutherland (n 33) 138.
} 
Daha çarpıcı bir farklılık çocuğun günlük yaşamının düzenlenmesi aşamasında ortaya çıkmaktadır. Bu alanda ALI İlkeleri ayrıntılı bir taraf anlaşması yapılmasına yönelik teşvik mekanizmaları ve anlaşma olmaması halinde yetkileri geçmiş ilişkilerle orantılı olarak paylaştırmaları ile farklılaşmaktadır.

Çocuğun menfaatleri açısından bakıldığında bu düzenlemenin bir yandan geçmiş ilişkilerinin devamlılığına dayandığı, dolayısıyla istikrar odaklı olduğ ${ }^{155}$, öte yandan da bu istikrarın her bir ailenin kendi dinamiklerine dayalı olarak belirlendiği, her tür aile modelinin kapsanmış olduğu görülmektedir ${ }^{156}$. Çocukla olan geçmiş ilişkilerin velayetin tayininde keskin bir çizgi olarak kullanılmasındansa anne ile baba arasındaki hak ve yetki paylaşımının oranını tayin edici bir ölçüt olarak kullanılmaları, bu modeli, velayeti tek başına birincil bakıcıya veren modelden ayırmaktadır ${ }^{157}$. Çocuğun menfaatinin değerlendirilmesinde niceliksel verilere dayanması ve varılacak çözümü bu yolla öngörülebilir kılması da bu sistemin ihtilaf konusu olabilecek hususları ve böylece çocuğun husumetten zarar görmesi ihtimalini azaltmasını sağlamaktadır ${ }^{158}$.

ALI İlkeleri'ne cinsiyet eşitliği açısından bakıldığında, öncelikle hâkimin takdir alanını sınırlandıran, önceki ilişki örüntüsüne dayalı objektif bir temel ölçütün varlı̆̆ının hâkimin çocuğun yararını belirlerken cinsiyete dayalı önyargılara göre hareket etmesi olasıllığını azalttığ 1 söylenebilir ${ }^{159}$. Öte yandan bu kural, çocuğun bakımına katkı sağlamak yönünde her iki ebeveyn için de teşvik edici bir yapı kurmaktadır $^{160}$ ve babaların çocuk bakımındaki rolü arttıkça daha da cazip hale gelebilir ${ }^{161}$. Kıta Avrupası'nda benimsenen şekliyle ortak velayet kuralının böyle bir teşvik sağladığı söylenemez, nitekim Avrupa'da benimsenen sistemlerde çocuğun günlük bakımına ilişkin görev paylaşımının takdiri hâkime bırakılmış ve böylece evlilik içindeki görev paylaşımından tamamen bağımsız olarak düzenlenebilmesi kabul edilmiştir. Oysa önceki bakım ilişkisine dayalı bir paylaşım, boşanma sonrası çocuğun bakımında daha aktif biçimde yer almak isteyen babalara, boşanma öncesinde de sorumluluğu paylaşmaları gerektiği yönünde bir mesaj göndermekte ve böylece eşitlikçi bir rol paylaşımına yönlendirmektedir ${ }^{162}$. Bir ebeveyn bu kurallar doğrultusunda çocukla daha fazla zaman geçirme imkânını elde ediyorsa bu durum

\footnotetext{
55 Sutherland (n 33) 138; Bartlett (n 14) 482-483; Caulley (n 13) 431; Scott ve Emery (n 34) 101.

156 Bartlett (n 14) 482-483.

157 Sutherland (n 33) 138.

158 Scott ve Emery (n 34) 71; benzer yönde Bartlett (n 14) 482; Graham (n 39) 327. Geçmiş bakım örüntüsünün ne olduğu, hangi ebeveynin daha iyi annelik veya babalık yapmaya muktedir olduğunun belirlenmesinden daha kolaydır. Bu kural çerçevesinde ilk etapta dikkate alınacak deliller, ailenin bakım pratiğini ve rutinlerini ortaya koyan davranışlar olacaktır, meğerki şiddet veya madde bağımlılı̆̆ı gibi, geçmiş bakım örüntüsünden ayrılmayı gerektiren sebepler bulunsun. İspatın konusunun ve delil aralığının daraltılmasının, mahkemeye başvurma ihtiyacını ve eşlerin birbirlerinin kusurlarına odaklanma eğilimlerini azaltarak prosedürü kolaylaştıracağı düşünülmektedir (Scott ve Emery (n 34) 102).

159 Graham (n 39) 32; Bartlett (n 14) 481.

160 Bartlett (n 14) 481.

161 Scott ve Emery (n 34) 71

162 Graham (n 39) 331; Kay (n 17) 35.
} 
mahkemenin cinsiyete dayalı ayrımcılığından değil, ebeveynlerin çocuğun bakımıyla ilgili daha önceden yaptıkları tercihlerden ötürü olmaktadır ${ }^{163}$. Ayrıca eğer her bir ebeveyn çocuğun bakımına belirli ölçülerde katılmışsa hiçbiri çocuğu ziyaret eden taraf konumuna indirgenmemiş olmaktadır ${ }^{164}$. Öte yandan kural, her türlü aile yapısına saygı duymakta ve her birinin içsel dinamiklerini dikkate alacak şekilde velayet ilişkisini yapılandırmaktadır. Böylece eşlerin daha önceki sorumluluk paylaşımının uzatılmasına dayalı bu düşünce, ailenin boşanma öncesindeki içsel dinamiklerini yansıtamayan kalıplaşmış velayet kurallarından farklı etkiler doğurabilmektedir ${ }^{165}$.

Bu modele ilişkin de eleştiriler gündeme getirilmiştir. Bunlar arasında kuralın geriye bakan ve gelecekte ihtiyaçların değişebileceğini göz önüne almayan bir kural olması ve çocukla fiilen geçirilen zamanın çocukla kurulan duygusal ilişkiyi yansıtmayabileceği sayılabiliir ${ }^{166}$. Keza, ebeveynlerin çocuğun bakımına görece eşit biçimde katıldıkları hallerde, bu durumun boşanma sonrasında da devamının sağlanması, çocuğun farklı evlerde kalmasını gerektirebileceğinden, Kıta Avrupası sistemlerinde ortak velayetin düzenlenmesi biçimlerinden olan dönüşümlü himayede karşımıza çıkabilecek sorunlar burada da geçerli olacaktır. Bu tür bir uygulamanın ebeveynler arasındaki iş birliğine dayandığı açıktır ${ }^{167}$. Yine yukarıda dönüşümlü himaye bahsinde işaret edildiği gibi çocuğun ev değiştirmesi gereken hallerde sistemin işlemesi için eşlerin çocuğun ihtiyaçlarını karşılama konusunda görece eşit imkânlara sahip olmaları gerekir. Bununla beraber anne ve babanın evlilik içinde çocuğa eşit biçimde baktıkları ve boşanma sonrasında da bu örüntünün devam ettirildiği ailelerde, eşlerin gelir elde etme açısından da birbirine yakın imkânlara sahip oldukları ve maddi olanaklar açısından eşitliğin evlilik düzeni içinde de zaten oluşmuş olduğu söylenebilir.

\section{Türk Hukukunda Velayetin Düzenlenmesi}

Hukukumuzda boşanma sonrasında velayet ve kişisel ilişki konuları TMK'nın 336. ve 182. maddelerinde düzenlenmiştir. Her iki konuda da esas alınacak ölçüt çocuğun üstün yararı olacaktır ${ }^{168}$. Velayetin düzenlenmesinde çocuğun üstün yararının tespitinde karşımıza çıkan sorunlardan biri boşanan ebeveynlerin velayeti birlikte icra etmeye devam etmelerinin çocuğun üstün yararına en uygun çözüm olarak dikkate alınıp alınamayacağıdır. Yine çocuğun üstün yararının tespitine ilişkin bir diğer mesele hâkimin tek başına velayete karar verdiği hallerde çocuğun üstün yararını tespit etmesine yarayan öngörülebilir eğilimler bulunup bulunmadı̆̆ıdır.

\footnotetext{
163 Kay (n 17) 43.

164 Scott ve Emery (n 34) 103.

165 Graham (n 39) 330.

166 Sutherland (n 33) 138; Kay (n 17) 46-47.

167 Kay (n 17) 45.

168 Bkz yuk n 23 'te anılan yazarlar. Çocuğun yararı kavramına ilişkin olarak bkz Öztan ve Öztan (n 21) 482; Elçin Grassinger (n 23) $57 \mathrm{vd}$. Aile için şiddetin önlenmesi amacının etkisi için bkz yuk n 21.
} 


\section{A. Çocuğun Üstün Yararının Tayininde Ortak Velayet Çözümünün Mümkün Olup Olmaması}

TMK'nın 336. maddesinin 3. fikrasında yer alan "Velâyet, (...) boşanmada ise çocuk kendisine birakılan tarafa aittir" hükmünden ne anlaşılması gerektiği tartışmalıdır. Bu hükmün tek başına velayeti zorunlu kılıp kılmadığı konusunda çeşitli görüşler ortaya atılmıştır.

Bazı yazarlara göre hüküm tek başına velayet düzenlemesini zorunlu kılmakta, ortak velayete izin vermemektedir ${ }^{169}$. Bu görüş benimsenirse ortak velayet seçeneğinin çocuğun üstün yararı değerlendirmesine hiçbir şekilde dâhil edilmemesi, ebeveynlerin anlaşması ve çocuğun görüşünün bu yönde olması gibi etmenlerin de sonucu değiştirmemesi gerekir. Hukukumuzdaki durumu bu şekilde saptayan yazarlardan bazıları, olması gereken hukuk açısından düzenlemeye eleştiriler yöneltmişler ve öneriler getirmişlerdir ${ }^{170}$.

Bazı yazarlar ise hükmün ortak velayete engel olmadığı ve yeni bir düzenlemeye gidilmeksizin de hâkimin ortak velayet ihtimalini çocuğun yararına uygun çözümün saptanmasında dikkate alabileceği fikrindedir. Bu görüşteki yazarlar vardıkları sonucu farklı gerekçelere dayandırmışlardır. Koçhisarlıŏlu, TMK m 336'da boşanmada velayet kime tevdi edilmiş ise ona ait olduğunun anlatılmak istendiğini, hükümde velayetin illa ki eşlerden birine tevdiinin gerektiği yönünde mutlak bir ifade yer almadığını, burada belirleyici olanın "taraf/eş" ifadesi olmadığını belirtmektedir. Yazara göre bu ifadenin tekil olarak kullanılmasının nedenini, boşanma ile tek başına velayete yönelik bir karar verilmesi ihtimalinin doğmasında aramak gerekir ${ }^{171} . \mathrm{Bu}$ çerçevede yazar, boşanmanın yan sonuçlarına ilişkin anlaşmada ortak velayete yönelik düzenleme yapılabileceği gibi, hâkimin kendisinin doğrudan çocuğun tevdii konusunda karar vermesi ihtimalinde de aynı sonucun geçerlikabul edilmesi gerektiğini savunmuştur ${ }^{172}$. Bazı yazarlar ise ortak velayetin mümkün olduğu sonucuna konuyla ilgili kanun boşluğu olduğu görüşünden yola çıkarak ulaşmışlardır. Bu görüşteki

\footnotetext{
169 Dural, Öğüz ve Gümüş (n 21) 143; Serozan (n 24) 255; Hüseyin Hatemi, Aile Hukuku, (7. Bası, On İki Levha 2019) 131.

170 "BM Çocuk Hakları Sözleşmesi ışığında yorumlanacak olan TC Anayasasının eşitlik ilkesi, çocuğun kişiliğini oluşturup geliştirme hakkı ve ana baba hakkı karşısında”, TMK'nın 336. ve 337. maddelerinin Anayasa'ya aykırılığının def'i yoluyla Anayasa Mahkemesi’nin önüne taşınması gerektiği yönünde, Serozan (n 24) 256.

171 Cengiz Koçhisarlıŏlu, Boşanmada Birlikte Velayet ve Yasanın Aşılması (Turhan Kitabevi 2004) 104-106. Yazar ayrıca boşanmanın velayetin birlikte yürütülmesini imkânsız hale getirdiği ve bu nedenle ancak tek başına velayetin söz konusu olabileceği yönündeki görüşlere de katılmamaktadır: “(...) boşanmanın birlikte velayeti sona erdirme gibi bir etkisi olamaz. Boșanmanın, ne analık, ne babalık ve ne de velayet ile doğrudan bir bağlantısı kurulabilir. Ve, nasıl ki, analık ve babalık boşanma ile sona ermemekte, süregitmektedir, aynı şekilde velayet de boşanma ile süregider/süregitmelidir diyoruz." (ibid 108).

172 Koçhisarlığlu (n 171) 106. Benzer şekilde, 336/III hükmünün kanunun mantığı ve getiriliş amacı kapsamında yorumlandığında hâkimin takdir yetkisini kısıtlayan bir hüküm olduğu sonucuna ulaşılamayacağı, boşanma sonrasında velâyetin hâkimin takdir yetkisi ile belirleneceği ve hâkimin takdir yetkisinin sınırının ise çocuğun yararı olduğu yönünde, Serdar (n 22) 184. Yazara göre kanunun mantığı mümkün olduğu kadar ana babanın velâyeti birlikte kullanmalarını sağlamak olup, boşanma sonrasında hâkime kuraldan ayrılma ve velâyeti ana babadan birine verebilme yönünde bir imkân sağlanmaktadır, Serdar (n 22) 180. TMK hükümlerinden velayet hakkının yalnız bir eşe verileceğinin kesin olarak çıkarılamayacağı yönünde, Ebru Ceylan, 'Türk Velayet Hukukunda Yeni Gelişmeler' (2018) 16 (181) Legal Hukuk Dergisi 35,55 .
} 
Öztan'a göre TMK m 336/III'ün amacı, çocuğun yararının en iyi şekilde korunması olup, hükmü tek başına velayeti zorunlu kılar şekilde yorumlamak hükmün amacından ayrılmak anlamına gelmektedir. Buna göre bu örtülü boşluğun doldurulması için hüküm amaca uygun olarak sınırlandırılmalı ve bu durum çocuğun yararına ise anne ve babaya velayetin ortak biçimde verilmesi yoluna gidilmelidir ${ }^{173}$. Yazara göre en azından anlaşmalı boşanmalarda, tarafların anlaşmasına ve çocuğun yararına uygun ise ortak velayet hâkim tarafindan karara bağlanabilmelidir ${ }^{174}$. Yine kanun boşluğu yaklaşımından yola çıkan bazı başka yazarlara göre kanunda kanun koyucunun ilgili düzenlemeyi yaparken ortak velayet kurumunun varl lğını bilmemesinden kaynaklanan gerçek bir boşluk bulunur ve hâkimin TMK m 1'e göre boşluğu doldururken ortak velayete karar vermesi mümkün olmalıdır ${ }^{175}$. Hukukumuzda ortak velayetin mümkün olduğu sonucuna Anayasa m $90 \mathrm{~V}$ hükmünün son cümlesi yardımılla varılabileceği de savunulmaktadır. Hüküm uyarınca "Usulüne göre yürürlüğe konulmuş temel hak ve özgürlüklere ilişskin milletlerarası andlaşmalarla kanunların aynı konuda farklı hükümler içermesi nedeniyle çıkabilecek uyuşmazlıklarda milletlerarası andlaşma hükümleri esas alınır." 2016'dan bu yana iç hukukumuzun parçası olan Avrupa İnan Hakları Sözleşmesi'ne ek 7 numaralı protokolün 5. maddesine göre "Eşler evlilikte, evlilik süresince ve evliliğin sona ermesi durumunda, kendi aralarında ve çocukları ile ilişkilerinde medeni haklar ve sorumluluklardan eşit şekilde yararlanırlar." Bazı yazarlara göre, bu düzenlemenin iç hukukumuza dâhil olması ile birlikte, tek başına velayeti öngören TMK m 336/III, Anayasa m 90 marifetiyle bertaraf edilebilir hale gelmiştir ${ }^{176}$.

173 Öztan (n 23) 1090-1091; benzer şekilde Akyüz (n 21) 235; Erlüle (n 25) 292.

174 Öztan (n 23) 1091.

175 Apaydin (n 77) 457-459.

176 Akıntürk ve Ateş (n 23) 313 ve 409; Ömer Uğur Gençcan, 'Ortak Velayet' (8.3.2017 Özel Sayısı) İzmir Barosu Dergisi 24, 26. Aynı yönde, protokolle birlikte Çocuk Haklarına Dair Sözleşme'nin 3, 7. ve 18. maddelerine ve Avrupa İnsan Hakları Sözleşmesi m 8'e de dayanarak, Kurt (n 77) 174. Protokol hükmünün amacından çocuğun üstün yararının gerektirdiği durumlarda ortak velayete karar verilebileceğinin anlaşıldığı, çocuğun üstün yararının gözetilmesi gerektiği ve evlilik birliğinin sona ermesinde anne baba eşitliğinin devam etmesi gerektiği dikkate alındığında TMK hükmünün ilga edildiği sonucuna varılması gerektiği yönünde, bkz Özdemir ve Ruhi (n 23) 345. Protokolün 5. maddesinin ilgili TMK hükümlerini ortadan kaldırmadığı ancak onlarla birlikte uygulanabilir bir hüküm olduğu yönünde, Güven (n 87) 40. Belirtilmelidir ki Avrupa İnsan Hakları Mahkemesi, Cernecki v Avusturya kararında o dönemde boşanma sonrasında birlikte velayete olanak tanımayan Avusturya hukukunu protokolün 5. maddesine aykırı bulmamıştır (Cernecki v Austria App no 31061/96 (ECtHR, 11.07.2000)). Karara konu olan olayda, Avusturya mahkemeleri, eşlerin anlaşmalı boşanma çerçevesinde ortak çocukların velayetini birlikte kullanmaya devam etmelerine ilişkin anlaşmalarını, Avusturya Medeni Kanunu'nun o dönemde yürürlükte olan ve boşanmada taraf anlaşmalarında eşlerin ancak velayetin içlerinden birine verilmesini kararlaştırabileceklerini öngören hükmünü dayanak göstererek onaylamamış ve velayeti anneye vermiştir. Avrupa İnsan Hakları Mahkemesi 5. maddenin taraf devletlerin çocuklar yararına gereken tedbirleri almalarına engel olmadığı yönündeki ikinci cümlesinden yola çıkarak, birlikte velayete engel olan Avusturya hukuku normunun, eşler arasında velayetin fiilen birlikte kullanılmasına engel olmadığını, anlaşmazlık çıkması halinde oluşabilecek belirsizliğin giderilmesi için açık bir çözüm öngörülmesi amacına ve böylece çocuğun korunması amacına hizmet eden bir çözüm olduğunu belirtmiştir. Mahkemeye göre olayda uygulanan medeni hukuk normu çerçevesinde boşanmadan sonra çocukla ilişkileri açısından eşler farklı şekilde konumlandırılmakta ve bu durum eşitlik ilkesine müdahale anlamına gelmektedir; ancak bu müdahale, velayetle ilgili olarak açık bir çözüm öngörmek suretiyle çocuğu korumak amacına dayandığından orantılıdır. Ancak dikkat edilmelidir ki bu kararda kanun koyucunun boşanmadan sonra birlikte velayet ihtimalini ortadan kaldırmasının protokolün 5. maddesinin ihlali olarak görülmemesine etki eden etmenlerden biri, olaya uygulanan hukuk sisteminin, velayete sahip olmayan ebeveyne de görüşme, bilgi alma ve bazı önemli kararlarda görüşüne başvurulması gibi haklar da tanımakta olmasıdır. Dolayısıyla kanımızca bu karar, bu hakları tanımadan sadece ziyaret imkânı tanıyan bir hukuk sisteminde de müdahalenin orantılı görüleceğine dair bir gösterge teşkil etmez. Karar için bkz https://hudoc.echr.coe.int/eng\#\{\%22fullte xt\%22:[\%22Cernecki\%22],\%22itemid\%22:[\%22001-5362\%22]\} Erişim Tarihi 11.05.2020. 
Ortak velayete karar verilmesinin de lege lata mümkün olduğu veya de lege feranda mümkün olması gerektiği kabul edildiğinde, ortak velayetin sistemimize nasıl entegre edilmesi gerektiğine ilişkin yeni bir sorunla karşılaşırız. Bu noktada mesele, ortak velayet ile tek başına velayet seçeneklerinden birinin genel kural olarak kabul edilip edilmeyeceğidir. Bu açıdan da öğretide ortak velayetin kural, tek başına velayetin istisna olmas 177 , ortak velayetin istisna olmas ${ }^{178}$ veya sadece gönüllülük esasına dayalı olarak kabul edilmesi ${ }^{179}$ ve bu tür bir ilişkilendirme yapmak yerine somut olaya göre hâkimin çocuğun yararına olan çözümü benimsemesi gerektiği yönünde ${ }^{180}$ görüşler ileri sürülmüştür.

Yargıda ise ortak velayet kurumu yakın zamana kadar adeta bir tabu olarak algılanmış, Türk hukukunun uygulandığı uyuşmazlıklar şöyle dursun, yabancı hukuk sistemlerinin ortak velayete ilişkin düzenlemeleri dahi mahkemeler tarafından kabul edilemez görülmüştür. Yabancı mahkemelerin ortak velayete ilişkin kararları kamu düzenine aykırı bulunmuş ve tenfiz talepleri reddedilmiştir ${ }^{181} .2017$ senesinde ise Yargıtay, olaya uygulanması gereken yabancı hukuk sistemindeki ortak velayet düzenlenmesinin ${ }^{182}$ ve ortak velayet çözümünü öngören yabancı mahkeme kararının ${ }^{183}$ Türk kamu düzenine "açıkça" aykırı olduğunu ya da Türk toplumunun temel yapısını ve temel çıkarlarını ihlal ettiğini söylemenin mümkün olmadığı yönünde kararlar vererek önceki içtihadından ayrılmıştır ${ }^{184}$. Bu gelişmeler Türk hukukunun velayete ilişkin çözümüne ilişkin tartışmaları yeniden canlandırmış ve Türk hukukunun uygulandığg ihtilaflarda da ortak velayetin önünü açan kararlar verilmeye başlanmıştır. Artık velayete ilişkin ihtilaflarda Bölge Adliye Mahkemeleri'nin ortak velayet çözümünü de ihtimaller arasında değerlendirdiği görülmektedir. Tespit edebildiğimiz kararlarda ortak velayetin gönüllülük esasına dayandığ1 yönünde bir anlayışın genel olarak kabul edildiği, eşlerin anlaşmasına dayalı olarak kabulünün

\footnotetext{
177 Koçhisarlığlu (n 171) 86 ve 149; Apaydın (n 77) 472; Gençcan (n 176) 27, ancak yazar, tek başına velayetin istisna olması gerektiğini belirtmekle beraber, ortak velayetin gönüllülük esasına dayalı olduğunu, velayetin eşlerden birine verilmesi istemi varsa çekişmelere neden olacağı için mahkemece ortak velayet düzenlemesinin yapılmaması gerektiğini de ifade etmektedir.

178 Özdemir ve Ruhi (n 23) 305, ancak yazarlar, birlikte velayeti gönüllülük esasına dayandırmamakta, çocuğun üstün yararı gereğince mahkeme tarafından re'sen de birlikte velayete hükmedilmesi gerektiğini ifade etmektedirler.

179 Boşanan eşlerin çocuğun yararına olarak ana baba sorumluluğunu beraberce devam ettirmeye istekli ve hazır olduğu hallerde birlikte velayetin istisnai olarak kabul edilmesi gerektiği yönünde, Cem Baygın, Soybă̆g Hukuku, (On İki Levha 2010) 268; birlikte velayetin "seçimlik bir hak" olarak düzenlenmesi gerektiği yönünde, M Erdem Aybay ve C Bülent Şen, 'Medeni Hukuk ve Sosyal Hizmet Bakış Açısıyla Birlikte Velayet Sorunu' (2016) 15(1) İstanbul Kültür Üniversitesi Hukuk Fakültesi Dergisi 589, 597; ortak talep olmadan birlikte velayete hükmedilmesinin amaçlanan faydayı sağlamayacağ yönünde, Güven (n 87) 44-46.

180 Kurt (n 77) 175; İnce (n 73) 221-222; Birinci Uzun (n 79) 157-158.

181 Ebru Şensöz Malkoç, Aile Hukukuna İlişkin Yabancı Kararların Tanınması (On İki Levha 2017) 442.

182 Yargıtay 2. HD, 15771/1737, 20.2.2017, <www.lexpera.com> Erişim Tarihi 11.05.2020.

183 Yargitay 2. HD, 18674/13800, 04.12.2017, <www.lexpera.com> Erişim Tarihi 11.05.2020.

184 Genel bilgi için bkz Şensöz Malkoç (n 181) 441 vd.
} 
mümkün olduğunun benimsendiği görülmektedir ${ }^{185}$. Söz konusu kararlarda ortak velayetin hukukumuzda uygulanabilirliğine dayanak olarak da Avrupa İnsan Hakları Sözleşmesi'ne ek 7 numaralı protokolün 5. maddesi ve eşler arasında eşitliği öngören bu hükmün Anayasa m 90 marifetiyle doğrudan uygulanabilir olması gösterilmektedir.

TMK m 336/III'ün taraf olduğumuz uluslararası sözleşmelere uygun biçimde yorumlanması sonucu ortak velayetin de hâkimin benimseyebileceği çözümlerden biri haline geldiğini kabul etmek gerekir. Böylece hâkim, tek başına velayet yanında ortak velayete de hükmedebilmelidir. Elbette bu yolun açılması olması, ortak velayete hangi şartlarda karar verilebileceğine ve fiilî bakım ilişkisinin nasıl düzenleneceğine ilişkin soruları da beraberinde getirir. Kanımızca tek başına velayeti mutlak kural olarak benimseyen bir hukuk sisteminin en eleştiri götürür tarafi, ebeveynler anlaşmış olmasına ve durumun çocuğun yararına da uygun olduğunun görünmesine rağmen ortak velayetin yine de olanaksız kabul edilmesidir. Hâkimin ortak velayete hükmedebilme yetkisinin tanınması ile bu hallerde ortak velayetin uygulamaya konulması mümkün hale gelecektir. Bu noktada çocuğun görüşüne de Çocuk Haklarına Dair Sözleşme'nin 12. maddesinin öngördüğü şekilde gereken ağırlık verilmelidir ${ }^{186}$. Ancak toplumumuzdaki uzlaşma kültürünün zayıflığı, ilk etapta gönüllülük esasına dayalı bir uygulamanın benimsenmesini, hâkimin tarafların ortak rızası hilafına bu yola gitmemesini gerektirmektedir; aksi durum ortak velayetten beklenen faydalara ulaşılamaması sonucunu doğuracaktır. Esasen yabancı ülkelerde de ortak velayet uygulaması aşamalı şekilde gelişmiş, ilk aşamada taraf anlaşmasına dayalı ortak velayet sistemi benimsenmiştir. Bizim hukukumuz açısından da bu yol benimsenmeli ve ortak velayetin re'sen karar verilebilen bir kurum haline gelip gelmeyeceği oluşacak tecrübeler 1şığında belirlenmelidir. Fiilî bakım ilişkisinin düzenlenmesinde de dönüşümlü himaye yönünde bir çözümün ilk etapta ebeveynlerin bu yöndeki anlaşmasına dayalı olarak ve elbette çocuğun üstün yararına en uygun çözüm olarak görünüyorsa benimsenmesi gerekir. Kanımızca taraf anlaşmasına dayalı olarak benimsenebilecek ortak velayet ve bu kapsamda dönüşümlü himaye çözümlerinin yerindeliğini değerlendirirken hâkimlerin kadın-erkek eşitliğine ilişkin bağıtlarımızı da göz önünde bulundurmaları, tarafların üzerinde anlaştıkları çözümün bu açıdan da taraf menfaatlerini zedeleyici olup olmadığına dikkat etmeleri aranmalıdır.

185 Örneğin, evlilik dışı doğan çocuğun velayetini birlikte kullanma yönündeki anlaşmanın taraflarca bildirilecek deliller serbestçe değerlendirilerek ve uzman görüşü alınarak değerlendirilmesi gerektiği yönünde, İstanbul 38 BAM, 2733/537, 12.04.2019; ancak boşanma davasında eşler arasında bu yönde anlaşma olmaması halinde ortak velayete hükmedilmemesi gerektiği yönünde, İstanbul 10 BAM, 226/9, 07.01.2019; Ankara 2 BAM, 3530/158, 05.02.2019, İzmir 2 BAM , 3781/179, 05.02.2019; kararlar için <www.lexpera.com> Erişim Tarihi 11.05.2020.

186 UN Committee on the Rights of the Children, 'The Right of the Child to Be Heard' (2009) General Comment No 12, https://tbinternet.ohchr.org/_layouts/15/treatybodyexternal/Download.aspx?symbolno=CRC $\% 2 \mathrm{fC} \% 2 \mathrm{fGC} \% 2 \mathrm{f} 12 \& \mathrm{Lang}=$ en Erişim Tarihi 11.05.2020. 


\section{B. Tek Başına Velayette Çocuğun Üstün Yararının Belirlenmesi}

Ortak velayetin kabulü mümkün hale gelmiş olsa da hukukumuzda ezici olarak uygulanmaya devam edilen model tek başına velayet modelidir. Tek başına velayet modeli çerçevesinde alınan kararlarda velayetin anne ile babadan hangisine verileceği ve bu çerçevede çocuğun üstün yararının nasıl saptanacağı hususu, velayetin ilk defa taraflardan birine verileceği boşanma davalarında olduğu gibi, velayetin değiştirilmesine yönelik davalarda da tartışılmaktadır. Her ne kadar kanun koyucu hâkimin takdir yetkisini sınırlandırıcı parametreler koymaktan kaçınmış olsa da ${ }^{187}$ Yargitay kararları incelendiğinde uygulamada bu konuda bazı genel değerlerin kullanıldığı ve velayetin düzenlenmesinde belirli bir örüntünün bulunduğu görülmektedir. Tespit edebildiğimiz kararlarda, bu açıdan velayetin boşanmayı takiben ilk defa düzenlenmesi ile ebeveynlerden birine verilmiş olan velayetin sonradan diğer ebeveyne verilmesi halleri arasında benzerlikler bulunmakta, iki durumda da velayete ilişkin karar alınırken çocuğun yararı kavramı benzer ilkeler çerçevesinde değerlendirilmektedir.

Yargıtay'ın bazı kararlarında velayetin düzenlenmesine ilişkin genel ilkeler ortaya konulmaktadır. Örneğin, yakın tarihli bir Hukuk Genel Kurulu kararına göre, "Ana ve babanın çocukların kişiliklerine ilişkin hak ve ödevleri, özellikle çocuklarına bakmak, onları görüp gözetmek, geçimlerini sağlamak, yetiştirilmelerini ve eğitimlerini gerçekleştirmektir. Bu bağlamda sağlayacağı eğitim ile istenilen ölçüde dürüst, kötü alışkanlıklardan uzak, iyi ahlâk sahibi, çalışkan ve bilgili bir insan olarak yetiştirmek hak ve yükümlülüğ̈̈ bulunmaktadır. (...) Ayrılık ve boşanma durumunda velâyetin düzenlenmesindeki amaç, küçügün ileriye dönük yararlarıdır. Başka bir anlatımla, velâyetin düzenlenmesinde asıl olan, küçüğün yararını korumak ve geleceğini güvence altına almaktır." 188 Böylece görülmektedir ki, temel nitelikte olan çocuğun üstün yararı ölçütünün uygulamaya konulmasında çocuğun "ileriye dönük yararları"na vurgu yapılmakta ve çocuğu "dürüst, kötü alışkanlıklardan uzak, iyi ahlâk sahibi, çalışkan ve bilgili bir insan olarak yetiştirmek" vazifesini eşlerden hangisinin yerine getirebileceği hususunun incelenmesi gerekmektedir. Bazı kararlarda bu ölçütler daha da somutlaşmış biçimde karşımıza çıkmaktadır. Bu yöndeki kararlara göre, "(...) velayetin belirlenmesi ve düzenlenmesinde, çocuğun cinsiyeti, doğum tarihi, eğitim durumu, kimin yanında okumakta olduğu, talepte bulunanın çocuğun ĕgitim durumu ile ilgilenip ilgilenmediği, sağlı̆̆l, sağlık durumuna göre tedavi olanaklarının kimin tarafindan sağlanabileceği gibi özel durumuna ilişkin hususlar ile ana babadan kaynaklanan özelliklerin de dikkate alınması kaçınılmazdır. Bu nedenle, mahkemece çocuğu başkasına bırakma, ihmal etme, kaçırma, iradi olarak terk etme, yönlendirme hususları ile tarafin velayet talebinin olup olmaması, şiddet uygulaması,

\footnotetext{
187 Aile içi şiddet konusunda bkz yuk n 21.

188 Yargıtay HGK, 1072/185, 21.02.2019; aynı şekilde, HGK, 483/1356, 27.9.2018; HGK, 2069/1179, 06.06.2018; HGK, 1567/1132, 23.05.2018, kararlar için bkz <www.lexpera.com> Erişim Tarihi 11.05.2020.
} 
sadakatsizliği, ekonomik durumu, mesleği, yaşadiğı ortam, kötü davranışı, alkol bağımlılı̆̆l, sağlı̆̆l, dengesiz davranışları dikkate alınmalıdır." ${ }^{89} \quad \mathrm{Bu}$ çerçevede mahkemelerin hem olumlu hem de olumsuz yönde dikkate alabilecekleri unsurlar belirlenmiş olmaktadır. Bununla beraber, Yargıtay çocuğun yararına yönelik bütüncül bir değerlendirme yapılması ve bu unsurlardan hiçbirinin tek başına değerlendirilmeye alınmaması gerektiğini, "Ana ve babanin yararlarl; ahlâki değer yargllarl, sosyal konumlarl gibi durumlarl, çocuğun üstün yararını etkilemediği ölçüde göz önünde tutulur" ifadeleriyle istikrarlı biçimde belirtmektedir ${ }^{190}$.

$\mathrm{Bu}$ genel parametreler, anne ile babanın velayetin dağılımında eşit imkâna sahip olduğu izlenimi verse de, Yargıtay'ın çocukların velayetinin anne bakım ve şefkatine muhtaç olmaları gerekçesiyle anneye verilmesi gerektiği kabulü ile hareket ettiği görülmektedir"191. Nitekim Yargitay'a göre, "Yaş̧̧a kü̧̈ük olan çocukların, anne şefkat, bakım ve ilgisini yaşayabilmeleri için, annenin bu görevi üstlenmesine engel bir durumu bulunmadlkça velayetin anneye verilmesi tercih edilmelidir" ${ }^{192}$. Bu ilke, "mahkemece ana yanında kalmasının çocuğun bedeni, fikri, ahlaki gelişmesine engel olacağı yönünde ciddi ve inandırıcı deliller bulunmadı̆̆ ve hemen meydana gelecek tehlikelerin varliğl da ispat edilmediğ ${ }^{\prime \prime}{ }^{193}$ sürece uygulanmaktadır. Yargıtay'ın, kardeşlerin üstün yararları gerektirmediği sürece ayrılmamaları gerektiği yönündeki içtihadı ${ }^{194}$ uyarınca da çocuklardan birinin velayetinin anne şefkatine muhtaç olması nedeniyle anneye verilmesi halinde yaşı daha büyük çocukların da anneye bırakılmaları ihtimali yüksek olmaktadır.

Babanın maddi durumunun daha iyi olmasının tek başına velayetin değiştirilmesini gerektirmeyeceğine ${ }^{195}$, kadına boşanma davasıyla ilgili olarak yüklenilen kusurlu davranışların ${ }^{196}$, bu arada sadakat yükümlülügüne aykırıllğın ${ }^{197}$ annenin velayet görevini üstlenmesine engel bir durum oluşturmayacağına, anne bakım ve şefkatine muhtaç çocuk açısından, annenin velayet hakkından feragat etmesinin, çocuğun

\footnotetext{
189 Yargitay HGK, 1567/1132, 23.05.2018, <www.lexpera.com> Erişim Tarihi 11.05.2020.

190 Yargitay HGK, 2066/15, 17.01.2019; HGK, 2069/1179, 06.06.2018, <www.lexpera.com> Erişim Tarihi 11.05.2020.

191 Öğretideki yaklaşım açısından, küçük çocuk ile anne arasındaki duygusal ilişkilerde yoğunluk olduğu gerekçesiyle küçük çocuklarda annenin tercih edilmesi gerektiği yönünde, bkz Öztan ve Öztan (n 21) 486.

192 Yargitay 2. HD, 9516/23409, 10.10.2013; 2. HD, 23744/9051, 04.05.2015; 2. HD 17775/15016, 04.06.2012; 2. HD, 23151/15842, 06.06.2013; 2. HD, 1767/22890, 20.12.2011; 2. HD, 16387/7820, 18.04.2016; kararlar için bkz <www. lexpera.com> Erişim Tarihi 11.05.2020.

193 Yargitay 2. HD, 17775/15016, 04.06.2012; 2. HD, 23744/9051, 04.05.2015, <www.lexpera.com> Erişim Tarihi 11.05.2020.

194 Velayet düzenlemesine konu birden fazla çocuk bulunduğu takdirde, çocukların kardeşlik duygusunu yaşayabilmeleri için üstün yararları gerektirmediği sürece velayetlerinin aynı ebeveyne verilmesinin tercih edilmesi gerektiği yönünde, bkz Yargitay 2. HD, 9516/23409, 10.10.2013; benzer şekilde, bkz 2. HD, 23744/9051, 04.05.2015; 2. HD, 17775/15016, 04.06.2012; 2. HD, 1767/22890, 20.12.2011; 2. HD, 16387/7820, 18.04.2016. Nitekim Yargitay'a göre "Kardeşlerin birbirinden ayrılmasının onların gelişimlerine olumsuz etki yapacă̆ı açık”tır, bkz 2. HD 23151/15842, 06.06.2013; kararlar için bkz <www.lexpera.com> Erișim Tarihi 11.05.2020.

195 Yargitay HGK, 1567/1132, 23.05.2018, <www.lexpera.com> Erişim Tarihi 11.05.2020.

196 Yargitay 2. HD, 14540/9974, 07.06.2011, <www.lexpera.com> Erişim Tarihi 11.05.2020.

197 Yargıtay 2. HD, 1767/22890, 20.12.2011<www.lexpera.com> Erişim Tarihi 11.05.2020.
} 
menfaatleri dikkate alındığında sonuç doğurmayacağına ${ }^{198}$ ilişkin kararlar da anne şefkatine muhtaç olma ölçütünün kuvvetini göstermektedir. Yargıtay, velayetin anneye verilmesine engel bir hususun ispatlanamadığını tespit edip anne şefkatine muhtaç olma gerekçesine dayanmaya karar verdiğinde, aksi yöndeki uzman görüşüne ${ }^{199}$ ve çocuğun görüşüne ${ }^{200}$ itibar edilmemesi gerektiği yönünde de hüküm kurmuştur.

Hangi faktörlerin bu kuralın uygulanmamasına sebep olacağına ilişkin olarak verilebilecek bir örnek, yabancı literatürde "yabancılaştırma" olgusu olarak ifade edilen, annenin çocuk ile baba arasında ilişki kurulmasına engel olması halidir. Buna ilişkin bir kararında Yargıtay, boşanma davası sırasında tedbir kararına istinaden geçici olarak velayeti tek başına icra eden annenin çocuğun baba ile görüşmesine engel olarak velayet hakkını kötüye kullandığını kabul etmiş ve bu durumu, çocuğun üstün yararı çerçevesinde, velayetin dava sonucunda babaya verilmesini hakl1 gösteren bir olgu olarak görmüştür. ${ }^{201}$ Öte yandan, dikkate alınabilecek tüm faktörlerin babayı işaret etmesi durumunda velayetin babaya verilmesinin kabul görmesi de olasıdır. Yargıtay bu çerçevede "alınan sosyal inceleme raporuna göre çocukların velayetlerinin babaya verilmesinin uygun olduğu, annenin velayet talebinden vazgeçtiği, kaldı ki ortak çocukların babanın yanında fiilen yaşamaya başladıkları, babanın yanındaki yaşam koşullarına alıştıkları ve babaları ile kalmak istediklerini beyan ettikleri" tespitlerinden yola çıkarak ve "değişen koşullara göre her zaman velayet düzenlemesi yapılabileceğinden", ortak çocukların velayetlerinin babaya bırakılmasına karar verilmesini isabetli bulmuştur ${ }^{202}$.

Soyut ve uzun vadeli bir perspektiften bakıldığında anne şefkatine muhtaç olma ölçütünün genel kural haline getirilmesinin eşitlikçi bir çözüm olmadığına yukarıda değinilmişti ${ }^{203}$. Ancak bilindiği gibi toplumumuzda evlilik içinde çocuk bakımını ezici biçimde anneler üstlenmekte, aile içindeki bu yerleşik iş bölümü, kadınların çalışma hayatındaki olanaklarını önemli ölçüde kısıtlamaktadır. Çocukların bakımını kadınların yaptığı bir toplumsal düzende hem çocuğun gerçekten anneye daha yakın

198 Yargitay 2. HD, 6082 /17993, 26.06.2013<www.lexpera.com> Erişim Tarihi 11.05.2020.

199 Yargitay 2. HD, 22443/18362, 02.07.2012, <www.lexpera.com > Erişim Tarihi 11.05.2020.

200 Yargıtay 2. HD, 16387/7820, 18.04.2016. Çocuğun üstün yararı gerektirdiği takdirde dinlenilmemesi veya görüşünün aksine karar verilmesi mümkündür. Velayet konusuna ilişkin bir kararında mahkemenin çocuğun görüşünü dikkate almama gerekçesi olarak taraflardan birinin çocuğu diğer ebeveyne yabancılaştırması ve böylece çocuğun iradesinin serbestçe oluşmasına ilişkin haklı şüphelerin oluşmasına dayandığı görülmektedir. Karara konu olan olayda çocuk, babaannesi ve dedesi ile mutlu olduğunu ve velayetin babada kalmasını istediğini beyan etmiş olmasına rağmen, çocuğun anne bakım ve şefkatine muhtaç olması nedeniyle velayetin anneye verilmesine karar verilmiş, bu sonuca varılırken çocuğu "baştan beri dede ve babaannenin sahiplenmeye çalışarak anne ile görüşüp aralarında olumlu bir ilişki gelişmesine izin verilmemesi” de göz önüne alınmıştır; bkz Yargıtay 2. HD, 23744/9051, 04.05.2015, <www.lexpera.com> Erişim Tarihi 11.05.2020.

201 Yargitay 2. HD, 17842/13832, 17.10.2016, 04.05.2015, <www.lexpera.com> Erișim Tarihi 11.05.2020. TMK'nın 324. maddesinde, anne veya babanın diğerinin çocuk ile kişisel ilişkisini zedelemekten, çocuğun eğitilmesi ve yetiştirilmesini engellemekten kaçınmakla yükümlü oldukları ve yükümlülüğün ihlalinin kişisel ilişki kurma hakkının reddedilmesi sonucuna götürebileceği öngörülmüştür. İşaret edilen kararda bu ilke velayetin tevdiine ilişkin olarak uygulanmış olmaktadir.

202 Yargitay 2. HD, 4980/12318, 16.12.2019, <www.lexpera.com> Erişim Tarihi 11.05.2020.

203 Bkz yuk II A 1. 
olması, hem de annenin kimliğinin esas olarak bu işlevi üzerinden kurulmuş olmas1 karşısında, evlilik sona erdiğinde velayetin anneye verilmesi olağan görünmektedir. Dolayısıyla ülkemizdeki toplumsal yapı dikkate alındığında bu kuralın soyut açıdan eşitlikçi olmamakla birlikte haklı ve makul gerekçelere dayandığı söylenebilir. Ancak anne şefkatine muhtaç olma ölçütünün somut durumun özelliklerinden bağımsızlaştırılarak, genel kural biçiminde uygulanmaya devam edilmesinin uzun vadede kadınların eşitlik taleplerinin aleyhine rol oynayacağı da görülmektedir. Anne şefkatine muhtaç olma ölçütü, babaların çocuk bakımına katılmasını teşvik edici nitelikte olmadığından mevcut aile içi dinamiklerini yeniden üretme sonucunu doğurmaktadır. Ayrıca, kadınların çalışma hayatına daha aktif biçimde katılmaya başlaması ile bu ölçüt, kadınların aleyhine sonuç doğurabilecek hale gelebilecek, aktif bir çalışma hayatı olan kadınların anne şefkatini veremeyecek durumda oldukları yönünde haksız bir izlenim oluşabilecektir. Keza anne şefkatine muhtaç olma ölçütünün hâlihazırda bilimsel verilere dayandırılmıyor olması ve hangi yaş aralığında uygulandığının belirsiz olması da bu kuralı keyfi değerlendirmelere açık hale getirmektedir. Kanımızca her ne kadar mevcut toplumsal yapıda görece adaletli görünebilse de, anne şefkatine muhtaç olma ölçütünün uygulanması için gereken şartların çerçevesinin çizilmesi ve ezbere uygulanan bir ölçüt olmasından çıkarılması, özellikle kadın ve erkek arasındaki iş bölümünün eşitlikçi biçimde yapılandırıldı̆̆ 1 aile tiplerinde duruma daha geniş bir perspektiften bakılması gerekir. Kuralın bilimsel verilerden, toplumsal gelişmelerden ve ailelerin iç dinamikleri ile geçmiş ilişkilerden soyutlanarak uygulanması geleneksel iş bölümü anlayışının tasdik edilmesine hizmet etmektedir.

\section{Değerlendirme ve Sonuç}

Boşanma sonrasında velayetin düzenlenmesine ilişkin hukuk kuralları, herkesin hemfikir olduğu şekilde, çocuğun üstün yararına uygun çözümün bulunmasını hedeflemektedirler. Çocuğun üstün yararı kavramı, sağladığı esnekliğin ve kararları bireyselleştirme imkânının korunması için hukuki tanımlamaların uzağında tutulmaktadır. Ancak bu esneklik, belirsizliği ve öngörülmezliği de beraberinde getirmektedir. $\mathrm{Bu}$ durumun yarattığı sakıncalardan birinin cinsiyet ayrımcılığına kapı açması olduğu düşünülmektedir. Ayrımcılık kendisini, karar organına annelik ve babalık rolleri hakkında kişisel değer yargılarını ön plana çıkarma yolunun açılması şeklinde göstermektedir. Cinsiyet rollerine ilişkin önyargılar, velayete ilişkin uyuşmazlıklarda bazen kadınların, bazen erkeklerin aleyhine rol oynamakta, çocuğun yararının diğer menfaatlerden üstün tutulması gereği de ayrımcı uygulamaların gerekçesi olarak sunulabilmektedir. Bu nedenledir ki velayet hukukunda çocuğun yararı öncelikli amaç olmakla beraber, tek amaç olmaktan çıkmış, hukuk kuralları kadın-erkek eşitliğine ilişkin sorunların kapsamına annelik ve babalık vazifelerini de dâhil eder hale gelmiştir. Gelinen noktada kabul edilmelidir ki, çocuğun yararı üstün 
nitelikte olmakla beraber, olası çözümlerden kadın-erkek eşitliğine uygun olanın kabul edilmesi, varılan sonuçların bu açıdan da değerlendirmeye tabi tutulması gerekir.

Velayete ilişkin düzenlemeler ve uygulamalar, bu alanda çeşitli kuralların uygulandığını göstermektedir. Bu kuralların amacı, çocuğun üstün yararı ilkesini öngörülebilir k1larak öngörülmezliğinin yarattığı sakıncaları bertaraf etmektir. Ancak bu kurallara münhasıran cinsiyet eşitliği açısından bakıldığında bazılarının öngörülmezliğin risklerinden biri olan ayrımcılığa çözüm bulmanın çok uzağında kaldıkları, tam tersine kadın ve erkek arasındaki geleneksel rol paylaşımını ve bundan doğan eşitsizlikleri destekledikleri görülmektedir. Bu noktada incelediğimiz konu açısından önemli olan soru, anne ve baba arasındaki rol dağılımına eşitlikçi biçimde yaklaşan ve ayrımcılık riskini en aza indiren bir genel kural koymanın mümkün olup olmadığıdır.

Eşitlikçi yaklaşımın kilit noktalarından biri sorumluluk paylaşımının etkin biçimde teşvik edilmesidir. Anne ve babayı çocuğun doğumundan itibaren eşitlikçi biçimde görev paylaşımı yapmaya yönlendiren bir uygulamanın kadın-erkek eşitliğine olumlu katkıda bulunacağı açıktır. Bu noktada dikkat edilmelidir ki ebeveyn-çocuk ilişkilerinde eşitliğe vurgu yapan bazı uluslararası belgeler de eşitliği sadece ayrılık sonrasına hasreder biçimde ele almamakta, anne ve babanın çocuğun doğumundan itibaren eşit biçimde çocuğun bakımına katılmaları gerektiğinin altını çizmektedirler ${ }^{204}$. Bu açıdan bakıldığında, annenin sadece cinsiyete dayalı olarak velayete sahip olması sonucunu doğuran anne şefkatine muhtaç olma ölçütünün, sorumluluk paylaşımını teşvik edici olduğu söylenemez; bu ölçüt kadın ve erkek arasındaki geleneksel rol dağılımının devamını desteklemektedir. Birincil bakıcı ölçütü cinsiyete dayalı bir ayrıma dayanmadığı için babaları bakıma katılmaya teşvik etmektedir; ancak son tahlilde ebeveynlerden birinin, çoğunlukla annenin tek başına velayeti alması sonucuna götürmesi ve diğer ebeveynin, çoğunlukla babanın, çocuğun bakımına esaslı biçimde katılması halinde dahi velayeti tamamen kaybetmesi sonucunun doğabilmesi bu kuralın sorumluluk paylaşımını teşvik edici etkisini azaltmaktadır. Kanımızca ortak velayet çözümü de, ister sadece hukuki yetkilerin paylaşımına, ister bunun yanında bakım yükümlülüğünün de paylaşımına dayansın, sorumluluk paylaşımını teşvik edici bir çözüm değildir. Boşanma sonrası aniden ve genel kural biçiminde gelen eşitlik, aile içindeki görev dağılımını değiştirmeye yönelik hiçbir teşvik yaratmamaktadır. Ortak velayetin kural olarak kabulü, eşitlik ilkesi açısından teşvik sorunu dışında da sorunlar barındırmaktadır. Evlilik birliği devam ederken çocuğa ilişkin sorumluluk yüklenmemiş tarafın, çoğunlukla babanın, boşanma sonrasında hak sahibi kılınmasının, o ana kadar çocuğun bakımını sağlamış

\footnotetext{
204 PACE, 'Equality and Shared Parental Responsibility: The Role of Fathers' (2015) Resolution No 1468, bkz yuk n 8; PACE, 'Gender Equality, Reconciliation of Private and Working Life and Co-Responsibility' (2013) Resolution No 1921, bkz yuk n 6 .
} 
olan ve meslek sürdürme imkânını ve dolayısıyla ekonomik kaynaklara erişimini bu nedenle ikinci plana atmış olan taraf, çoğunlukla anne açısından eşitlikçi bir düzenleme olduğu kabul edilemez ${ }^{205}$. Ortak velayet, sadece hukuki yetkilerin birlikte kullanılması anlamına geliyorsa, ebeveynlerden birine sadece müdahale yetkisini muhafaza etme hakkı tanınmış olmaktadır. Durum, bakım yükümlülüğünün de paylaşılması anlamına geliyorsa yine bu noktada gelen eşitliğin, evlilik sırasında bakım yükümlülüğünü üstlenmiş olan tarafın durumunu olumlu biçimde değiştirdiği söylemek güçtür. Bilakis bakım yükümlülüğünün boşanma sonrasında dönüşümlü hale gelmesinin, o zamana kadar bakım yükümlülüğünü üstlenmiş kişinin, çoğunlukla annenin fakirleşmesine sebep olduğu gözlemlenmektedir. Nitekim bakım yükümlülüğünün boşanma sonrasında aniden eşit biçimde bölünmesi halinde, önceden iş hayatında olan kişi, çoğunlukla baba, çalışma zamanını azaltarak çocuğa bakım zamanı yaratabilmektedir, ancak hiç çalışmayan ya da diğerinden daha az çalışan taraf, çoğunlukla anne, çocuk bakımını paylaşarak tasarruf ettiği zamanda çalışma hayatına katılma imkânını artıramamaktadır ${ }^{206}$. Keza, dönüşümlü himayenin masraflara simetrik biçimde katlanılmasına sebep olmas ${ }^{207}$ düşük gelirli tarafı boşanmanın ekonomik sonuçlarıyla daha da sert biçimde yüz yüze getirmektedir. $\mathrm{Bu}$ nedenlerle çocuğun bakımının boşanma sonrasında paylaştırılması, temelde devamlı biçimde çalışma hayatında olan, baba ile ev içi iş bölümünü daha önceden de yerleştirmiş olan ve babanın bakım ve eğitim yetilerine güven duyan anneler açısından baba ile benzer şekilde hayata devam etme imkânı sağlamakta ${ }^{208}$ ve bu çerçevede eşitlikçi bir çözüm olabilmektedir.

Bu durum karşısında ortak velayete yönelik bir çözümün, fiilî ve kapsayııı bir eşitlik amacına hizmet edebilmesi için, evlilik içinde çocuk bakımına eşit katılmaya, dolayısıyla her iki eşe de çalışma hayatında bulunma açısından firsat yaratmaya teşvik edecek şekilde yapılandırılması gerekir. Ebeveynlerin çocuğun doğumundan itibaren sorumluluk almaya teşvik edilmeleri ise, boşanma sonrasındaki durumun, evlilik sırasındaki görev paylaşımının uzantısı olarak düşünülmesini gerektirir. $\mathrm{Bu}$ konuda yukarıda açıkladığımız, ALI İlkeleri'nce getirilmiş öneriler bize göre görece en sağlıklı çözümleri sunmaktadır ${ }^{209}$. ALI İlkeleri, hem karar alma yetkisinin hem de bakım sorumluluğunun paylaştırılmasında geçmişteki ilişki yapısının devamlılı̆̆ına dayalı bir sistem kurarak, çocuğun hayatında var olmak isteyen ebeveyne bu varlığ evlilik ilişkisi içinde de göstermesi gerektiği yönünde bir mesaj vermektedirler. Özellikle fiilî bakım sorumluluğunun paylaştırılmasında geçmiş bakım örüntüsünün

\footnotetext{
${ }_{205}$ Avrupa Konseyi Parlementerler Meclisi’nin 2235 sayılı kararında belirtildiği gibi, ekonomik alandaki ayrımcılık biçimleri ev içi cinsiyete dayalı eşitsizliklerle bağlantı içindedir; eşitsizlik türleri irdelenirken ve çözüm üretilirken bu bağlantı her zaman akılda tutulmalidır (PACE, 'Empowering women in the economy' (2018) Resolution No 2235, para 8), <https:// assembly.coe.int/nw/xml/XRef/Xref-XML2HTML-en.asp?fileid=25023\&lang=en> Erişim Tarihi 11.05.2020.

206 Wellenhofer (n 124) 2762.

207 Côté (n 72) 88.

208 ibid 87.

209 Bkz yuk II B 3.
} 
devamlılığına yönelik bir velayet düzenlemesi, çocuğun himayesine sahip olmak için aile içinde de bakıma katılmayı, dolayısıyla eşitlikçi bir aile içi iş bölümünü teşvik etmektedir. Ancak fiilî bakım açısından geçmiş bakım örüntüsünün devam ettirilmesi, daha önce de belirtildiği gibi, ebeveynler arasında yüksek seviyede bir iletişimin yanı sıra her bir ebeveynin çocuğun maddi ve manevi ihtiyaçlarını çocuğun yaşantısındaki istikrarı zedelemeyecek şekilde karşılayacak finansal olanaklara sahip olmasını gerekli kılar. Bu da eşitlikçi bir velayet çözümünün çocuğun menfaatine uygun biçimde işlemesinin ancak belirli bir sosyal sınıfa ait aileler arasında, azınlıkta kalan bir çözüm olarak kabul edilebilmesi anlamına gelir ${ }^{210}$. Pratik engeller nedeniyle bu devamlılığın sağlanamadığı veya babanın çocuğun fiilî bakımına zaten hiç katılmamış olduğu hallerde, geçmiş bakım örüntüsüne dayalı, yani eşit sorumluluğu teşvik eden bir ortak velayet sisteminde dahi sadece hukuki karar alma yetkisi açısından devamlılık sağlanabilmekte ve böylece hukuki müdahale yetkisine sahip kılınan bir ebeveyn, çocuğa fiilen bakma açısından bütün sorumlulukların dışına çıkmış olmaktadır ${ }^{211}$. Görüldüğü gibi, en eşitlikçi görünen düzenleme çerçevesinde bile, ortak velayetin genel kural olarak kabulü eşitlikçi bir rol paylaşımını genel biçimde desteklememektedir. Uyumlu bir birlikte ebeveynlik ilişkisinin başka biçimlerde de elde edilebileceği göz önüne alındığında ${ }^{212}$, ortak velayetin çocuğun menfaatine kural olarak en uygun çözüm olduğunu kabul etmek için de sebep bulunmamaktadır.

Görüldüğü gibi, boşanma sonrasında bakım yükümlülüğünün de cinsiyetten bağımsız olarak paylaşılmasının sağlandığı istisnai haller dışında genel kural niteliğindeki çözümlerin genel biçimde eşitlikçi çözümler getirdiğini iddia etmek güçtür. Bu kurallar, çocuğun üstün yararı standardının belirsizliğinin yarattığı diğer bazı sorunlara çare olabilirler, ancak hiçbiri anne ve baba arasındaki eşitliği sağlamak açısından, somut olayın şartlarından soyutlanmış biçimde, genel olarak kabulü mümkün bir çözüm sağlamamaktadır.

Çocuğun üstün yararı standardının yarattığı belirsizliğin ayrımcı uygulamalara açtığı kapının daraltılması için benimsenebilecek bir diğer çözüm, bu standardı somut olaya uygulayan karar organına, uygulayacağı yöntemle ilgili sınırlar çizmek olabilir. Çocuğun üstün yararı ilkesinin esnekliğini olumlu yanı olarak belirleyen Birleşmiş Milletler Çocuk Hakları Komitesi Genel Yorumu'nda bu esnekliğin manipülasyona da kapı açabileceği belirtilmiş, verilen örneklerde anne ve babaların velayet davalarında çocuğun üstün yararı kavramını kötüye kullanmalarına ve

\footnotetext{
210 Çözümün yaygınlaşması için ortak sorumluluğun daha genel nitelikteki aile politikaları ile desteklenmesi ve ebeveynlere finansal destek sağlanması gerektiği yönünde, Cottier, Widmer, Girardin, Tornare (n 95) 331.

211 Eşitlik ilkesine uygun olmayan bu durumun etkilerinin yumuşatılması, ancak birlikte karar alma yetkisinin de yeniden yapılandırılması, birlikte kullanılacak yetkilerin alanının birlikte yaşayan ebeveynlere göre daha dar çizilmesi, çocuğa fiilen bakan kişiye görece geniş bir hareket alanı bırakılması ile mümkün olabilir. Bu açıdan ancak çocuğun hayatını geri dönüşü olmayan biçimde şekillendirecek kararların birlikte velayete konu olması gerekir.

212 Cottier, Widmer, Girardin, Tornare (n 95) 309
} 
kendi menfaatlerini savunmalarına değinilmiştir (34 numaralı paragraf) ${ }^{213}$. Ancak Genel Yorum'da çocuğun üstün yararı kavramına ilişkin baştan belirlenecek karine niteliğindeki çözümlerin çocuğun yararını belirlemeye hizmet edemeyeceğinin, bunlardan kaçınılması gerektiğinin altı çizilmiş, kavramın içeriği belirlenirken izlenmesi gereken bir yöntemsel çerçeve belirlenmiş ve bu yolla öngörülebilirlik sağlanmaya çalışılmıştır. Buna göre,

i. Çocuğun üstün yararı belirlenirken belirli bir olayda anlamlı olan tüm etmenlerin birbirleri ile tartılmaları, bu tartımın çocuğun üstün yararına yönelik değerlendirmenin amacının sözleşmede çocuklara tanınan hakların tam ve etkin kullanımını ve çocuğun bütünsel gelişimini sağlamak olduğu unutulmadan yapılması gerekir (82 numaralı paragraf).

ii. Değerlendirme yapılırken çocuğun durumunun değişeceği unutulmamalıdır. Karar organları nihai ve geri dönüşsüz kararlar yerine değiştirilebilen veya uyarlanabilen türden kararlar almalıdır. Bunun için sadece karar anındaki fiziksel, duygusal, eğitimsel ve diğer nitelikteki ihtiyaçlar değil çocuğun gelişiminin muhtemel senaryoları da değerlendirilmeli ve bunlar kısa ve uzun vadede analiz edilmelidir. Bu bağlamda kararlar çocuğun şimdiki ve gelecekteki durumunun devamlılığını ve istikrarını sağlamalıdır ( 84 numaralı paragraf).

iii. Çocuğun korunmasına ilişkin önlemlerinin çocuğun haklardan yararlanması önlemleriyle ilintili biçimde değerlendirilmesi gereken hallerde çocuğun yaşı ve olgunluğu yol gösterici olmalıdır (83 numaralı paragraf).

iv. Çocukla birlikte çalışma deneyimi olan ve alınan bilgiyi objektif biçimde değerlendirebilecek çocuk psikolojisi, çocuk gelişimi ve diğer sosyal gelişim uzmanları ile birlikte hareket edilmesi, çocuğun üstün yararının mümkün olduğu ölçüde disiplinler arası bir ekip tarafından değerlendirilmesi gerekir ( 94 numaralı paragraf).

v. Alınan kararın gerekçesi tüm olgusal şartları içermeli, bunlardan hangilerinin çözüm açısından anlamlı bulunduğuna, bunların çocuğun üstün yararı belirlenirken ne şekilde tartıldığına ilişkin açıklama yapılmalı, varılan sonuç çocuğun taleplerinden ayrılıyorsa bunun sebebi açıkça belirtilmelidir (97 numaralı paragraf).

Genel Yorum'da bu genel ilkelerin yanında ebeveynlik sorumluluklarının anne ve baba arasında paylaşılmasının genellikle çocuğun üstün yararına uygun olduğu belirtilmiş, ancak alınacak kararlarda temel ölçütün belirli bir çocuğun üstün yararının nerede olduğunun belirlenmesi olduğu da ifade edilmiştir. Genel Yorum'a göre, kanunların bu sorumlulukları otomatik olarak tek bir ebeveyne veya her ikisine ortak

${ }_{213}$ UN Committee on the Rights of the Children, 'Right of the Child to Have His or Her Best Interests Taken as a Primary Consideration' (2013), General Comment No 14, bkz yuk n 30. 
vermesi çocuğun yararlarına aykırıdır ${ }^{214}$. Çocuğun üstün yararını değerlendirirken hâkimin çocuğun her iki ebeveynle de ilişkilerini muhafaza etme hakkını o belirli olayda anlamı olan diğer faktörlerle birlikte göz önünde tutması gerekir (67 numaralı paragraf).

Görülmektedir ki Genel Yorum'a göre çocuğun üstün yararına ilişkin doğru kararın alınması, genel varsayımlar türetilmesinden değil, her somut olayda belirli bir karar alma yöntemi izlenilmesinden geçmektedir. Genel Yorum, çocuğun üstün yararı kavramına ilişkin olduğundan doğal olarak bu kavramı esas alan bir yöntemsel çerçeve çizilmiştir. Anne baba arasındaki eşitliğin de ulaşılması gereken amaçlardan biri olduğu dikkate alındığında, bu yöntemin içine eşler arasında bakım sorumluluğuna ilişkin adaletin sağlanması ve cinsiyete dayalı ayrımcılık yapılmaması yönünde ilkeler de eklenmelidir. Kanımızca hâkimlerin bu anlamda dikkate almaları gereken ilkeler arasında (i) çocukla geçmişteki ilişkiler ve bakım sorumluluğunun geçmişte ne şekilde paylaşıldığı (ii) velayete ilişkin varılacak sonucun tarafların çalışma hayatına katılmasını olanaklı kılıp kılmayacağı, (iii) velayete ilişkin varılacak sonucun ekonomik açıdan zayıf olan tarafın fakirleşmesi sonucunu doğurup doğurmayacağı unsurları da yer almalı, hâkimler ayrıca alınan kararlarla verilen mesajların aile içinde eşit rol paylaşımını teşvik edici etkisi olup olmadığı konusunda da farkındalıkla hareket etmelidirler. Hâkimlere bu yönde bir çerçeve çizilmesi, somut olaya ilişkin kararları bu çerçeve doğrultusunda gerekçelendirme yönünde bir gereklilik yaratacak, böylece hem ezbere uygulamaların azaltılması sağlanabilecek, hem de kanun yolunda denetimin yapılabilmesi için daha fazla veri içeren kararlar alınması mümkün olabilecektir. Bu yaklaşım nihai yetkiyi yine hâkime vermekte ve dolayısıyla ayrımcılık ihtimalini tamamen ortadan kaldırmamaktadır, ancak karar alma sürecini şeffaf hale getirerek varılan sonuçları tartışılabilir hale getirebilir.

Son kertede, çocuğun üstün yararını, anne ve baba arasındaki eşitliğin sağlanması hedefiyle bağdaşacak şekilde gözeten iki sistem bulunduğunu görüyoruz. Ortak velayetin kural olarak benimsenmesi, ancak bakım sorumluluğunun da eşit biçimde dağıttılmasını sağladığı ve bu yönde bir ailevi yapının kurulmasını teşvik ettiği ölçüde eşitlikçi bir çözümdür. Bu çözümün uygulamaya konulmasındaki güçlükler, bu tür bir ortak velayet sisteminin kural biçiminde benimsenmesi yerine, çocuğun üstün yararının karinelerden uzak bir standart olarak tutulması ve çözümün somut olaya göre belirlenmesini zorunlu kılabilir. Bu durumda ise çocuğun üstün yararı görüntüsü altında cinsiyet ayrımcılığ yapılmasının önüne geçilmesi için hâkimlerin izlemesi gereken yöntem belirlenmeli, kararları bu yöntem çerçevesinde gerekçelendirme yönünde zorunluluk getirilmelidir.

214 Benzer biçimde PACE, 'Gender Equality, Reconciliation of Private and Working Life and Co-Responsibility' (2013) Resolution No 1921, bkz yuk n 6. 
Kadınlara ve erkeklere hem kamusal hem de özel alanda bireysel tercihlerine uygun seçenekler sağlayan yasal teşviklerin gelişmesi tüm hukuk alanlarının diyalog içinde hareket etmesini gerektiren bütüncül bir sorundur. Anne ve baba arasında eşitlik de bu bütüncül sorunun parçalarından biri olarak ele alınmalıdır. Fırsat eşitliğini önceleyen bir hukuk düzeninin gelişmesi ile toplumsal kadın ve erkek rolleri arasındaki ayrım bulanıklaşacak, böylece hem annelere hem de babalara karşı önyargılar da azalacaktır. Çocuklara ilişkin kararların gerçekten çocukların menfaatine hizmet eder hale gelmesi de bu önyargıların aşılması ile mümkün olacaktır.

Hakem Değerlendirmesi: Dış bağımsız.

Çıkar Çatışması: Yazar çıkar çatışması bildirmemiştir.

Finansal Destek: Yazar bu çalışma için finansal destek almadığını beyan etmiştir.

Peer-review: Externally peer-reviewed.

Conflict of Interest: The author has no conflict of interest to declare.

Grant Support: The author declared that this study has received no financial support. 


\section{Bibliyografya/Bibliography}

Akıntürk T ve Ateş D, Türk Medeni Hukuku-Aile Hukuku, İkinci Cilt, (21. Bası, Beta 2019).

Akyüz E, Çocuk Hukuku-Çocukların Hakları ve Korunması, (6. Bası, Pegem Akademi 2018).

Apaydın E, 'Ortak Hayata Son Verilmesi Sonrası Ortak Velayet Hususunda Yasal Düzenleme Gereği’ (2018) 9(1) İnönü Üniversitesi Hukuk Fakültesi Dergisi 445-476.

Aybay ME ve Şen CB, 'Medeni Hukuk ve Sosyal Hizmet Bakış Açısıyla Birlikte Velayet Sorunu' (2016) 15(1) İstanbul Kültür Üniversitesi Hukuk Fakültesi Dergisi 589-615.

Balomatis A, 'Das Wechselmodell in Europa' (2016) Neue Zeitschrift für Familienrecht 833-836.

Bartlett KT, 'Child Custody in the 21st Century: How the American Law Institute Proposes to Achieve Predictability and Still Protect the Individual Child's Best Interests', (1999) 35(3) Willamette Law Review 467-483.

Baygın C, Soybă̆ Hukuku, (On İki Levha 2010).

Birinci Uzun T, 'Türk Medeni Kanunu'na Göre Velayetin Kullanılması ve Çocuğun Yüksek (Üstün) Yararı İlkesi Doğrultusunda Boşanmada ve Evlilik Dışı İlişside Birlikte Velayet Modeli' (2016) 6 Hacettepe Üniversitesi Hukuk Fakültesi Dergisi 135-166.

Boyd SB, 'Can Child Custody Law Move Beyond the Politics of Gender' (2000) 49 University of New Brunswick Law Journal 157-168.

Büchler A ve Clausen S, 'Art. 298' iç Ingeborg Schwenzer ve Roland Fankhauser (edr), FamKommentar Scheidung Band I: ZGB (3. Bas1, Stämpfli Verlag AG 2017), 403-444.

Büchler A ve Vetterli R, Ehe Partnershaft Kinder (3. Bas1, Helbing Lichtenhahn 2018).

Carbone J ve Cahn N, 'The Triple System of Family Law' (2013) Michigan State Law Review 1185-1229.

Caulley AM, 'Equal Isn't Always Equitable: Reforming the Use of Joint Custody Presumptions in Judicial Child Custody Determinations' (2018) 27 (2) Boston University Public Interest Law 403-460.

Ceylan E, 'Türk Velayet Hukukunda Yeni Gelişmeler' (2018) 16 (181) Legal Hukuk Dergisi 35-68.

Choffat G, 'Réflexions sur la réforme de l'autorité parentale conjointe: une promesse déçue?'(2015) 2 La semaine judiciaire 167-186.

Côté D, 'La garde partagée des enfants : nouvelles solidarités parentales ou renouveau patriarcal?' (2004) 23 (3) Nouvelles Questions Féministes 80-95.

Cottier M, Widmer E, Girardin M ve Tornare S, 'La garde alternée' (2018) Die Praxis des Familienrechts 297-332.

Council of Europe Committee of Ministers, 'Recommendation of the Committee of Ministers to Member States on Parental Responsibilities', Recommendation No. R (84) 4.

Council of Europe, 'Council of Europe Convention on Preventing and Combating Violence Against Women and Domestic Violence' (2011) Treaty No 210.

Council of Europe, 'Gender Equality Strategy 2018-2023'.

Dekeuwer-Defossez F, 'L'intérêt (supérieur) de l'enfant : consensus, instrumentalisation ou subversion ?' iç Emmanuel Putman, Marie-Ėve Pancrazi, Michel Buy, Bertrand Fages, Anne Laude, Dominique Velardocchio, Mélanges en l'honneur de Jacques Mestre, (LGDJ 2019) 345-359.

DiFonzo JH, 'Dilemmas of Shared Parenting in the 21st Century: How Law and Culture Shape Child Custody' (2015) 43 (4) Hofstra Law Review 1003-1022. 
DiFonzo JH, 'Toward a Unified Field Theory of the Family: The American Law Institute's Principles of the Law of Family Dissolution' (2001) Brigham Young University Law Review 923- 960.

Dionisi-Peyrusse A ve Pichard M, 'L'autorité parentale et la persistance des inégalités de genre' iç Stéphanie Hennette Vauchez, Marc Pichard, Diane Roman (edr), La loi et le genre, Études critiques de droit français (CNRS 2014) 485-503.

Dural M, Öğ̈̈z T ve Gümüş MA, Türk Özel Hukuku Cilt III, Aile Hukuku (14. Bası, Filiz Kitabevi 2019).

Elçin EG, 'Çocuğun Menfaati Gereği Çocukla İlgili Uyuşmazlıklarda Görüşünün Alınmaması Gereken Durumlar' iç Evgen Gülçin Elçin-Arzu Genç Arıdemir (edr), Çocuk Hakları Çalışmalart-I (On İki Levha 2017) 1-25.

Erlüle F, İsviçre Medeni Kanunu'nda Yapılan Değişiklikler Işı̆̆ı̆ıda Boşanmada Birlikte Velayet (Yetkin Yayınları 2019).

Gençcan ÖU, 'Ortak Velayet' (8.3.2017 Özel Say1s1) İzmir Barosu Dergisi 24-31.

Graham KT, 'How the ALI Child Custody Principles Help Eliminate Gender and Sexual Orientation Bias from Child Custody Determinations' (2001) 8 (1) Duke Journal of Gender Law 323-331.

Grassinger GE, Türk Medeni Kanununda Yer Alan Velayet Hükümleri Kapsamında Küçügüun Kişi Varlığının Korunması İçin Alınacak Tedbirler (On İki Levha 2009).

Günay M, ‘6284 Sayılı Kanuna Göre Koruyucu ve Önleyici Tedbirler’ (2012) 3 (4) Türkiye Adalet Akademisi Dergisi, 650-651.

Güven K, 'Türk Hukukunda Evliliğin Sona Ermesi Halinde ve Evlilik Dışı İlişkide Velayet Hakkının Geldiği Son Nokta: Ortak Velayet' (2018) 4 (1) Başkent Üniversitesi Hukuk Fakültesi Dergisi 11-64.

Guillod O ve Burgat S, Droit de la famille, (4. Bas1, Collection Neuchateloise Helbing Lichtenhahn 2016).

Hakimpour D, 'Distributing Children as Property: The Best Interest of the Children or the Best Interest of the Parents' (2017) 37 (1) Children's Legal Rights Journal 128-167.

Hatemi H, Aile Hukuku, (7. Bası, On İki Levha 2019).

Hausheer H, Geiser T ve Aebi-Müller R, Das Familienrecht des Schweizerischen Zivilgesetzbuches, (6. Bas1, Stämpfli Verlag 2018).

Hennemann H, 'BGB § 1671' iç Dieter Schwab, Münchener Kommentar zum BGB, Band 10 (8. Bas1, C H Beck 2020).

Hennemann H, 'BGB § 1687' iç Dieter Schwab, Münchener Kommentar zum BGB, Band 10 (8. Bas1, C H Beck 2020).

İnce N, 'Karşılaştırmalı Hukukta ve Türk Hukukunda Evlilik Birliğinin Boşanma İle Sona Ermesi Durumunda Birlikte Velâyet' (2018) 9 (4) Türkiye Adalet Akademisi Dergisi 189-229.

Jacobs SB, 'The Hidden Gender Bias Behind the Best Interest of the Child Standard in Custody Decisions' (1997) 13 Georgia State University Law Review 845 -901.

Kaiser D, 'Gemeinsame elterliche Sorge und Wechselmodell' (2008) Familie Partnerschaft Recht 143-148.

Kaiser D, 'Elternwille und Kindeswohl - für das gemeinsame Sorgerecht geschiedener Eltern' (2003) Familie Partnerschaft Recht 573-578.

Kay HH, 'No-Fault Divorce and Child Custody:Chilling out the Gender Wars' (2002) 36 (1) Family Law Quarterly 27-47. 
Kelly RF ve Ward SL, 'Allocating Custodial Responsibilities at Divorce: Social Science Research and The American Law Institute's Approximation Rule' (2002) 40 (3) Family Court Review 350-370.

Kiremitçi Öztürk M, 'Boşanma Sürecinde Ortak (Müşterek) Velayet ve Toplumsal Bakış Açısı', iç Evgen Gülçin Elçin-Arzu Genç Arıdemir (edr), Çocuk Hakları Çalışmaları-I (On İki Levha 2017) 59-117.

Koçhisarlığlu C, Boşanmada Birlikte Velayet ve Yasanın Aşılması (Turhan Kitabevi 2004).

Kostka K, 'Elterliche Sorge und Umgang bei Trennung und Scheidung - unter besonderer

Berücksichtigung der Perspektive des Kindes' (2005) Familie Partnerschaft Recht 89-95.

Kurt LM, 'Boşanma Durumunda Birlikte (Ortak) Velâyet' (2018) 9 (2) İnönü Üniversitesi Hukuk Fakültesi Dergisi 157-186.

Lang C, 'Elterliche Sorge' iç Klaus Shnitzler (ed), Münchener Anwaltshandbuch Familienrecht (5. Bas1, C H Beck 2020).

Melli MS, 'The American Law Institute Principles of Family Dissolution, the Approximation Rule and Shared-Parenting' (2005) 25 (3) Northern Illinois University Law Review 347-362.

Özdemir H ve Ruhi AC, Çocuk Hukuku (Ders Kitabı), (3. Bası, On İki Levha 2019).

Öztan B, Aile Hukuku (6. Bas1, Turhan Kitabevi 2015).

Öztan B ve Öztan F, 'Boşanmada Velayetin Tevdii' (2016) 1 (2) Çankaya Üniversitesi Hukuk Fakültesi Dergisi 473-495.

PACE, 'Equality and Shared Parental Responsibility: The Role of Fathers' (2015) Resolution No 1468.

PACE, 'Gender Equality, Reconciliation of Private and Working Life and Co-Responsibility' (2013) Resolution No 1921.

PACE, ' Gender Equality and Child Maintenance' (2018) Resolution No 2207.

PACE, 'Empowering women in the economy' (2018) Resolution No 2235.

Schmid J, 'BGB § 1687' iç. Werner Schulz ve Jörn Hauß (edr), Familienrecht, Handkommentar, (3. Bas1, Nomos 2018).

Schwarz ER, 'When Neutral Doesn't Really Mean Neutral: Louisiana's Child Custody Laws - An Attempt to Erase Gender Bias in the Name of Neutrality' (1996) 42 Loyola Law Review 365390.

Scott ES ve Emery RE, 'Gender Politics and Child Custody: The Puzzling Persistence of the BestInterest Standard' (2014) 77 Law and Contemporary Problems 69-108.

Scott ES, 'Pluralism, Paternal Preference, and Child Custody' (1992) 80 California Law Review 615- 672 .

Serdar İ, 'Birlikte Velayet' (2008) 10 (1) Dokuz Eylül Üniversitesi Hukuk Fakültesi Dergisi 155197.

Serozan R, Çocuk Hukuku (İkinci basıdan tıpkı bası, Vedat Kitapçılık 2017).

Sutherland EE, 'Child Custody and Cognate Concepts: The Challenges' iç Barbara Stark, Jacqueline Heaton (edr), Routledge Handbook of International Family Law (Routledge 2019) 127-143.

Şensöz Malkoç E, Aile Hukukuna İlişkin Yabancı Kararların Tanınması (On İki Levha 2017).

UN Committee on the Rights of the Children, 'The Right of the Child to Be Heard' (2009) General Comment No 12. 
UN Committee on the Rights of the Children, 'Right of the Child to Have His or Her Best Interests Taken as a Primary Consideration' (2013), General Comment No 14.

Usta S, Velayet Hukuku (On İki Levha 2016).

Vogel H, 'Ausgewählte Probleme aus dem Recht der elterlichen Sorge bei getrennt lebenden Eltern' (2005) Familie Partnerschaft Recht 65-70.

Wardle LD, Duncan WC ve Nolan LC, 'United States of America' iç Walter Pintens (ed) International Encyclopaedia of Laws: Family and Succession Law (Wolters Kluwer 2018).

Wellenhofer M, 'Gemeinsam getragene Elternverantwortung nach Trennung und Scheidung' (2018) Neue Juristische Wochenschrift 2758-2762.

Yee JW, 'Child Custody Decisions: Should the Best Interests of the Child Standard Be the Primary Determinant' (2019) 65 (1) Wayne Law Review 175-196. 
